\title{
COMMENTS
}

\section{HOW STANDING HAS FALLEN: THE NEED TO SEPARATE CONSTITUTIONAL AND PRUDENTIAL CONCERNS}

\author{
Craig R. GotTlieb $†$
}

\section{INTRODUCTION}

Ms. Amy Skilbred made her living as a wildlife biologist. She regularly has traveled outside of the United States to study wildlife. She visited Sri Lanka specifically to observe and study various endangered species, such as the Asian elephant. Ms. Skilbred had a "fixed intention to return to" Sri Lanka for vocational purposes," although the timing of her return depended, in part, on the cessation of the Sri Lankan Civil War. ${ }^{2}$ When it became clear that construction projects in Sri Lanka, funded, in part, by American agencies, threatened to destroy the habitat of the Asian elephant, ${ }^{3}$ Defenders of Wildlife, an environmental group to which Ms. Skilbred belonged, brought suit. Defenders sought to preserve the species that Ms. Skilbred studied and planned to continue studying through an order requiring the Secretary of the Interior to restore an initial interpretation of section 7(a)(2) of the Endangered Species Act of $1973^{4}$ which had extended the geographic scope of the Act's protection of endangered species to actions taken by American agencies in foreign nations. Defenders alleged an injury to Ms. Skilbred in the form of a detriment to her studies and to the enjoyment that she derived from observing the Asian elephant. ${ }^{5}$

† A.B. 1991, Princeton University; J.D. Candidate 1994, University of Pennsylvania. I would like to first extend thanks to two faculty members, Robert Fox and Frank Goodman, whose advice helped make this Comment possible. Next, I would like to thank the following students: Stuart Sklar, Chad Eisenberger, Tony Klapper, Brett Lawrence, and Megan Jacobson, whose time and concern were most appreciated. Finally, most importantly, and most obviously, I would like to thank my phenomenal parents.

${ }^{1}$ Brief for Respondents at 24, Lujan v. Defenders of Wildlife, 112 S. Ct. 2130 (1992) (No. 90-1424).

2 See Lujan, 112 S. Ct. at 2138.

${ }^{3}$ See Respondents' Brief at 23, Lujan (No. 90-1424).

Pub. L. No. 93-205, 81 Stat. 884 (1973) (codified as amended at 16 U.S.C. $\S \S 1531-1544$ (1988 \& Supp. IV 1992)).

${ }^{5}$ See Respondents' Brief at 23, Lujan (No. 90-1424). 
Did she possess the required level of personal interest that would justify giving her and Defenders access to the federal judicial system?

It has become virtually obligatory to begin an article related to the doctrine of standing by criticizing the Supreme Court's treatment of the topic. ${ }^{6}$ The Court itself has admitted on occasion that "the concept of 'Art[icle] III standing' has not been defined with complete consistency in all of the various cases decided by this Court which have discussed it."

Essentially, the standing inquiry focuses on "whether the litigant is entitled to have the court decide the merits of the dispute or of particular issues." 8 Standing does not focus on the merits but is rather "a preliminary jurisdictional requirement" necessary to establish that a litigant is entitled to judicial action. ${ }^{9}$ Consequently, the courts must define a consistent notion of standing that does not erroneously deprive litigants of judicial recourse but does preclude frivolous lawsuits.

The need to address the issue of standing is a relatively recent phenomenon. The term "does not appear to have been commonly used until the middle of our own century." ${ }^{10}$ The emergence of

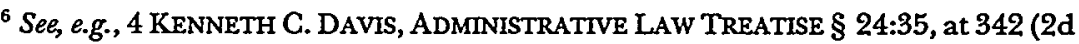
ed. 1983) (describing standing law as "permeated with sophistry"); Abram Chayes, The Supreme Court 1981 Term-Foreword: Public Law Litigation and the Burger Court, 96 HARV. L. REV. 4, 23 (1982) (noting that after pretending to apply a consistent standing analysis, the Court ignores the doctrine and "chooses up sides and decides the case"); William A. Fletcher, The Structure of Standing, 98 YALE L.J. 221, 290 (1988) (" $[T]$ he Supreme Court has failed to articulate an intellectual framework that can satisfactorily explain the results in cases already decided, or that can be usefully employed to shape legal analysis in cases yet to come."); Gene R. Nichol, Jr., Rethinking Standing, 72 CAL. L. REV. 68, 68 (1984) ("In perhaps no other area of constitutional law has scholarly commentary been so uniformly critical." (footnote omitted)).

${ }^{7}$ Valley Forge Christian College v. Americans United for Separation of Church \& State, Inc., 454 U.S. 464, 475 (1982). Circuit courts have also had difficulty in finding a consistent standard. See O'Hair v. White, 675 F.2d 680, 685 (5th Cir. 1982) ("[T] $]$ he doctrine remains opaque and does not admit of easy application." (footnote omitted)); McKay v. Heyison, 614 F.2d 899, 903 (3d Cir. 1980) (noting that "the law of standing has often been confusing").

${ }^{8}$ Warth v. Seldin, 422 U.S. 490, 498 (1975); see also DAvis, supra note 6, § 24:2, at 212 ("The standing question is a simple one: Who may litigate?"); Antonin Scalia, The Doctrine of Standing as an Essential Element of the Separation of Powers, 17 SuFFoLk U. L. REV. 881, 882 (1983) ("'Standing] is an answer to the very first question that is sometimes rudely asked when one person complains of another's actions: 'What's it to you?").

${ }^{9}$ Fletcher, supra note 6, at 223.

${ }^{10}$ Joseph Vining, Legal IDENTIty: The Coming of Age of Public LAW 55 
the standing doctrine coincided with the vast extension of government protections offered to private citizens, ${ }^{11}$ and the consequent need to define which claims against government inaction should properly be heard in the federal courts. ${ }^{12}$

The Supreme Court's latest venture into the law of standing is Lujan v. Defenders of Wildlife. ${ }^{13}$ In Lujan, Defenders of Wildlife sued the Secretary of the Interior, alleging that he erroneously applied section 7(a)(2) of the Endangered Species $\mathrm{Act}^{14}$ by promulgating a regulation that limited the scope of section 7 to those actions that are in the United States. ${ }^{15}$ The Act, which requires federal agencies to consult with the Secretary of the Interior as to possible adverse effects of agency action on endangered species, ${ }^{16}$ was previously interpreted by the Secretary to apply not merely to the United States but to foreign nations as well. ${ }^{17}$ The plaintiffs sought a declaratory judgment that the new regulation's limitation

(1978) (discussing the etymology of the term "standing").

"See Chayes, supra note 6, at 9 ("As Congress and administrative agencies extended protection to a broad array of . . . interests, lawsuits involving the validity of governmental action or inaction, rather than asserting private civil rights, have come to dominate federal civil dockets . . . ."); Richard B. Stewart, The Reformation of American Administrative Law, 88 HARV. L. REV. 1669, 1725 (1975) ("The growth of governmental activity has made ... common law liberty and property rights an inadequate measure of the private interests entitled to seek judicial intervention.... The perceived need to protect new classes of private interests . . . has produced a responsive expansion of standing rights.").

${ }^{12}$ See 13 Charles A. WRicht ET Al., Federal Practice and Procedure § 3531, at 340-41 (2d ed. 1984) (stating that " [standing] has been very much tied to litigation asserting the illegality of governmental action" since in classical private lawsuits, standing is self-evident: "[c]laims of private wrongdoing . . . are asserted by persons obviously having the enforceable interest").

13112 S. Ct. 2130 (1992).

14 The section provides:

Each Federal agency shall, in consultation with and with the assistance of the Secretary, insure that any action authorized, funded, or carried out by such agency . . . is not likely to jeopardize the continued existence of any endangered species or threatened species or result in the destruction or adverse modification of habitat of such species ....

16 U.S.C. $\$ 1536(\mathrm{a})(2)$ (1988).

${ }^{15}$ See 50 C.F.R. $\$ 402.01$ (1992).

${ }^{16}$ Consultation is a procedural requirement of the Endangered Species Act which insures that agency action "is not likely to jeopardize the continued existence of any endangered species." 16 U.S.C. $\$ 1536$ (a)(2) (1988). The Secretary and the federal agency together consider the impact of agency action on an endangered species. See id.; see also Lujan, 112 S. Ct. at 2158 (Blackmun, J., dissenting) ("Consultation is designed as an integral check on federal agency action, ensuring that such action does not go forward without full consideration of its effects on listed species.").

${ }^{17}$ See Lujan, 112 S. Ct. at 2135. 
of the scope of the Act to the United States was in error. ${ }^{18}$ They also sought "an injunction requiring the Secretary to promulgate a new rule restoring [the Secretary's] initial interpretation" that the geographic scope extended to foreign nations. ${ }^{19}$ The plaintiffs claimed injuries in the form of a lost vocational interest on behalf of their member, Ms. Skilbred (and a few other similarly situated plaintiffs), due to the impending extinction of an endangered species. ${ }^{20}$ The Court held that the plaintiffs had no standing. ${ }^{21}$

The Court currently draws its standing requirements from two types of considerations-constitutional and prudential. Constitutionally, "a plaintiff can have standing only if he satisfies the "case or controversy' requirement of Article III." ${ }^{\text {22 }}$ Once a plaintiff satisfies Article III, she must then satisfy prudential concerns, which "arise from a perceived institutional need for judicial self-restraint rather than from the Constitution itself. ${ }^{23}$ While it may seem relatively easy to distinguish between constitutional and prudential concerns, courts often demonstrate "confusion as to whether the . . . standing bar is constitutional, or instead prudential."24

If a court can deny access to a litigant by either a constitutional limitation or a prudential limitation, one may wonder why, beyond formalistic concerns, it matters which limitation a court uses. It matters, however, because the courts have less flexibility when dealing with constitutional limitations as opposed to prudential limitations. With respect to constitutional considerations, neither the courts nor Congress can "create standing in cases in which article III would deny it. ${ }^{25}$ If a litigant does not satisfy the case or

${ }^{18}$ See id.

${ }^{19} I d$.

${ }^{20}$ See id. at 2138.

${ }^{21}$ See id. at 2146.

22 Fletcher, supra note 6, at 222 (citing Linda R.S. v. Richard D., 410 U.S. 614, 617 n.3 (1973)).

${ }^{23}$ David A. Logan, Standing to Sue: A Proposed Separation of Powers Analysis, 1984 WIS. L. REV. 37, 46.

${ }^{24}$ City of S. Lake Tahoe v. California Tahoe Regional Planning Agency, 625 F.2d 231, 235 (9th Cir.), cert. denied, 449 U.S. 1039 (1980).

${ }^{25}$ Chayes, supra note 6, at 23 (footnote omitted); see also Havens Realty Corp. v. Coleman, 455 U.S. 363, 372 (1982) (noting that Congress can only extend standing to the full limits of Article III); DAvIs, supra note 6, § 24:5, at 225 (noting that the Court's position is that "Congress lacks power to confer standing on 'any person' unless the person shows injury"); Fletcher, supra note 6, at 222 (explaining that standing may only be statutorily conferred "[a]ssuming that Article III has been satisfied"); Jonathan Poisner, Comment, Environmental Values and Judicial Review After Lujan: Two Critiques of the Separation of Powers Theory of Standing, 18 
controversy requirement of Article III, she may not be granted standing under any circumstances. The prudential limitations, however, are "subject to elimination by the Court or by Congress." ${ }^{26}$ As for the courts, since prudential limitations are not constitutionally imposed, "a court has discretion on the question of whether to apply a prudential standing limit." While courts will generally adhere to prudential limits, they can "still grant[] standing to plaintiffs in exceptional circumstances." 28 Congress too has discretion to override prudential limitations. ${ }^{29}$ It can "confer standing by statute when ... a plaintiff would have been denied standing on prudential grounds. ${ }^{\text {s0 }}$

Therefore, when a court identifies a limitation as constitutional which the court should have identified as prudential, the court actually prevents future courts and Congress from considering situations where the prudential concerns might be outweighed by countervailing considerations. Consequently, litigants who might otherwise satisfy both constitutional and prudential requirements are unnecessarily excluded from court.

ECOLOGY L.Q. 335, 353 (1991) (noting that Congress "may not expand jurisdiction beyond the article III limitations" (footnote omitted)).

${ }^{26}$ Scalia, supra note 8 , at 885 .

${ }^{27}$ Ellen J. Bullock, Acid Rain Falls on the Just and the Unjust: Why Standing's Criteria Should Not Be Incorporated into Intervention of Right, 1990 U. ILL. L. REV. 605, 614 (footnote omitted); see also Preston v. Heckler, 734 F.2d 1359, 1365 (9th Cir. 1984) ("Prudential principles do not constitute 'limitation[s] on judicial power ...." (quoting Valley Forge Christian College v. Americans United for Separation of Church \& State, Inc., 454 U.S. 464, 475 (1982))).

${ }^{28}$ Bullock, supra note 27, at 614; see also Warth v. Seldin, 422 U.S. 490, 500-01 (1975) (noting that the Court's "usual reluctance to exert judicial power" in the presence of prudential considerations may be outweighed by countervailing considerations).

${ }^{29}$ See Bullock, supra note 27, at 615 ("Standing's prudential limits are not only within the discretion of the Court, but are also within the discretion of Congress."); Chayes, supra note 6, at 23 (noting that Congress can "override" prudential limitations).

${ }^{30}$ Fletcher, supra note 6, at 222-23. Consequently, if Congress explicitly confers standing to overcome prudential limits, "then the Court's 'prudential' hesitation is [automatically] overcome." Id. at 252. Congress can "expand standing to the full extent permitted by Art[icle] III, thus permitting litigation by one "who otherwise would be barred by prudential standing rules." Gladstone, Realtors v. Village of Bellwood, 441 U.S. 91, 100 (1979) (quoting Warth, 422 U.S. at 501). Therefore, an explicit grant of standing by Congress, such as a citizen-suit provision of a statute, is a "legislative overruling of all [judicial] prudential standing limitations." Bullock, supra note 27, at 615. Absent such an explicit congressional grant of standing, courts have discretion in deciding whether or not to apply prudential limits. 
A numerical hypothetical may best elucidate the grave ramifications of confounding prudential factors with constitutional ones. Assume that the constitutional minimum for standing is arbitrarily labelled as fifty. A litigant possessing a constitutional level of sixty would satisfy Article III. A court could still prevent a litigant from obtaining judicial access if the litigant implicated a prudential concern. Problems arise, however, when the Supreme Court denies access to a litigant on constitutional grounds when, in reality, the Court should be limiting access due to prudential concerns. The result is that the constitutional minimum has been increased from its previous level of fifty to the new level of sixty. Future courts and Congress, which lack the discretion to override constitutional limits, must then deny standing to future plaintiffs who do not satisfy the increased constitutional minimum. This denial is particularly problematic when the future plaintiffs both satisfy the original constitutional minimum and do not implicate any of the previous prudential worries which motivated the Supreme Court to deny standing to the original plaintiff. Nonetheless, such a litigant would be denied judicial access. ${ }^{31}$

This Comment examines the relationship between constitutional and prudential requirements for standing. While the Court in Lujan seems to think it can discern the relationship between constitutional and prudential requirements, ${ }^{32}$ in reality the Court raises the confusion to an unprecedented level. This Comment shows how the Supreme Court has traditionally combined the two limitations, harming litigants who deserve judicial access, and it demonstrates how a clear separation of the two limitations would allow litigants to gain judicial access. Part I explores the Court's traditional three-pronged constitutional analysis. Part II shows how the Court imported what should be prudential limitations into the supposedly constitutional analysis and illustrates how Lujan has done so to an extent never before seen. Finally, Part III explores the negative consequences of such importation and shows how separately identifying each limitation would eliminate these consequences.

${ }^{31}$ For examples of cases where lower courts are constrained by the Supreme Court's confusion of constitutional and what should be prudential concerns, see infra notes $395-491$ and accompanying text.

${ }^{32}$ See Lujan, 112 S. Ct. at 2136 (explaining that "the core component of standing is . . . the case-or-controversy requirement," while a smaller part of the analysis is the "mere[] prudential considerations"). 


\section{The Constitutional Analysis}

\section{A. What Makes a Concern Constitutional}

While the courts and Congress may weigh countervailing considerations to overrule prudential limitations, neither branch may override constitutional limitations under any circumstances. Therefore, the Article III limitation on standing should be based upon concerns that manifest themselves in every situation and cannot be diminished by countervailing factors.

There are several justifications proposed for the doctrine of standing, such as the assurance of truly adverse litigants, federalism, or separation of powers. ${ }^{33}$ Consider the importance of the first rationale: the assurance of adverse litigants. Article III always demands that the "litigants could be relied upon to satisfy the needs of a tribunal accustomed to deciding disputes as a result of adversary litigation .... ${ }^{m 4}$ The judicial system cannot function properly without a minimum degree of zealous advocacy from adverse participants, and there can be no countervailing exceptions to this requirement. The presence of zealous advocacy "assure[s] that concrete adverseness which sharpens the presentation of issues upon which the court so largely depends for illumination of difficult" questions. ${ }^{35}$ By requiring a vigorous adversary contest, standing serves the purpose of assuring a clear presentation of the issues so that a court can make an informed decision on the merits and produce logical precedent. The requirement of zealous advocacy "tends to assure that the legal questions presented to the court will be resolved, not in the rarified atmosphere of a debating society, but in a concrete factual context conducive to a realistic appreciation of the consequences of judicial action. ${ }^{36}$ Furthermore, "a court may decide the case with some confidence that its decision will not pave the way for lawsuits which have some, but not all, of the facts of the case .... ${ }^{n 7}$

ss Commentators typically focus on these three justifications. See Fletcher, supra note 6, at 222 (adversity of litigants); Gene R. Nichol, Jr., Abusing Standing: $A$ Comment on Allen v. Wright, 133 U. PA. L. REv. 635, 649 (1985) (federalism); id. (separation of powers). This Comment also considers the seldom articulated justifications of internationalism and military deference.

${ }^{34}$ WRIGHT, supra note 12, § 3531.1, at 362.

${ }^{35}$ Baker v. Carr, 369 U.S. 186, 204 (1962).

${ }^{36}$ Valley Forge Christian College v. Americans United for Separation of Church \& State, Inc., 454 U.S. 464, 472 (1982).

${ }^{37}$ Id. 
Although "the Framers gave almost no indication of what the [Article III case or controversy requirement] meant, ${ }^{n 8}$ the major concern "with the functional needs of effective adversary presentation has become" the core of Article III analysis. ${ }^{39}$ The Court's constitutional requirement "focuses on the desired end of concrete adversity. ${ }^{40}$

Moreover, the Supreme Court's recently developed threepronged Article III test ${ }^{41}$ provides a further piece of evidence that the constitutional barrier to standing is rooted in the promotion of zealous advocacy. The Court has established that for a plaintiff to satisfy the Article III standing requirement, she must pass a threepronged test: "First, the plaintiff must have suffered an 'injury in fact' .... Second, there must be a causal connection between the injury and the conduct complained of . . . . Third, it must be 'likely' ... that the injury will be 'redressed by a favorable decision." 42

Each element of the three-pronged test directly produces zealous advocacy. First, one can see a correlation between the zealousness of the advocacy and the degree of the injury. It seems more likely that an injured litigant will have a greater incentive than an uninjured litigant to put forth her best case. ${ }^{43}$ Second, a correlation exists between the rigor of the issue presentation and the degree to which the defendant caused the injury. A plaintiff is

${ }^{38}$ Gene R. Nichol, Jr., Justice Scalia, Standing, and Public Law Litigation, 42 DURe L.J. 1141, 1150 (1993) (quoting James Madison's circular assertion that tribunals deal with matters "of a Judiciary nature" in 2 RECORDS OF THE FEDERAL CONVENTION OF 1787, at 430 (Max Farrand ed., 1911)).

${ }^{39}$ WRIGHT, supra note $12, \S 3531.1$, at 363 .

${ }^{10}$ Mark V. Tushnet, The Sociology of Article III: A Response to Professor Brilmayer, 93 HARV. L. REV. 1698, 1706 (1980).

${ }^{11}$ See Teresa W. Roseborough, Allen v. Wright: Standing Beyond the Bounds of Article III, 63 N.C. L. REV. 1015, 1019 n.32 (1985) ("The Supreme Court's standing test is intended to determine whether the issue before the Court is presented in the context of an [Article III] case or controversy.").

${ }^{12}$ Lujan, 112 S. Ct. at 2136 (citations omitted); see also Allen v. Wright, 468 U.S. 737, 751 (1984) ("A plaintiff must allege personal injury fairly traceable to the defendant's allegedly unlawful conduct and likely to be redressed by the requested relief."); Valley Forge, 454 U.S. at 472 (outlining a similar test).

Commentators have challenged the appropriateness of the existence of various prongs of this three-pronged test. See, e.g., LAURENCE H. TRIBE, AMERIGAN CONSTITUTIONAL LAW \$ 3-18, at 131 (2d ed. 1988) (arguing that "an autonomous causation requirement need not be a desirable part of ${ }^{\prime \prime}$ the standing question). This Comment does not address the merits of the existence of the prongs themselves. Instead, assuming the propriety of the existence of the various prongs, the Comment argues that the Supreme Court has consistently manipulated the prongs.

43 See Baker, 369 U.S. at 204 (requiring plaintiffs to have suffered enough injury to assure proper issue presentation). 
much more likely to have the incentive to bring a zealous case against a defendant who actually caused the injury. ${ }^{44}$ Finally, the redressability requirement also furthers effective adversarial presentation. It follows logically that the plaintiff has greater incentive to bring forth a strong suit when her injury is redressable. ${ }^{45}$ The Court has established its three-pronged constitutional test in order to guarantee itself "an actual factual setting" in which to decide cases. ${ }^{46}$

For these reasons, the constitutional justification for standing should be based in the assurance of zealous advocacy. Conversely, the other possible justifications, such as separation of powers, federalism, military deference, and internationalism, should not be rooted in the Article III limitations.

Consider the separation of powers concern. Several sources explicitly link Article III limitations on standing and the separation of powers. ${ }^{47}$ This concern, however, should be rooted in the prudential analysis and should remain quite distinct from the constitutional limitation. Many cases and a plethora of commenta-

44 See Tushnet, supra note 40, at 1707 n.36 (explaining that the causation "requirement does no more than restate the personal stake requirement, for without such a causal relationship, it is unclear that a remedy will benefit the plaintiff; therefore he has no [incentive to bring] the case").

${ }^{45}$ See Louis L. Jaffe, The Citizen as Litigant in Public Actions: The Non-Hohlfeldian or Ideological Plaintiff, 116 U. PA. L. REV. 1033, 1037 (1968) ("[U]nless the plaintiff is a person whose legal position will be affected by the court's judgment, he cannot be relied on to present a serious, thorough, and complete argument.").

${ }^{46}$ Valley Forge, 454 U.S. at 472 . One apparent problem with the three-pronged test is that it appears to be both under-inclusive and over-inclusive in its assurance of zealous advocacy. It is over-inclusive in the case of an impoverished plaintiff who has suffered a constitutionally adequate injury but who does not have the money to obtain the legal counsel necessary to produce effective advocacy. Such a person will be allowed into court despite an inability to bring forth a zealous case. Alternatively, the test is under-inclusive in the case of a wealthy plaintiff who has suffered no injury but can afford to pay for counsel who can zealously argue the case. Such a person will be denied standing despite the ability to zealously argue a case. This underinclusivity and over-inclusivity do not seem to be problematic. Certainly the Article III constraints on standing were not designed to favor wealthy litigants over poor litigants. While the Court's three-pronged test may not have a perfect correlation to zealous advocacy, it misses this perfection only by rejecting a system of judicial access based upon wealth.

${ }^{47}$ See Allen v. Wright, 468 U.S. 737, 752 (1984) ("[S]tanding is built on a single basic idea-the idea of separation of powers."); id. at $761 \mathrm{n} .26$ (noting that the components of Article III are to be interpreted in light of "separation of powers principles"); 13 WRIGHT, supra note $12, \S 3531.1$, at 363 (noting the recent trend of including separation of powers in the Article III analysis); Scalia, supra note 8 (entitling his article The Doctrine of Standing as an Essential Element of the Separation of Powers). 
tors have explicitly criticized the linkage between Article III and separation of powers. ${ }^{48}$ If separation of powers concerns are not distinguished from the Article III calculus, both the courts and Congress will be harmed. As for harm to the courts, one need look no further than the Supreme Court's recently developed threepronged test of constitutionality ${ }^{49}$ to understand why courts will be harmed if separation of powers are not isolated from the constitutional analysis of standing. When a court wants to deny standing due to the supposedly constitutional worry of separation of powers, it must link the denial of standing to one of the three prongs of the Supreme Court's Article III test.

The problem is that there is a bad fit between the three requirements and separation of powers. ${ }^{50}$ Consider, for example, the constitutional requirement of redressability. "Redressability asks only whether the judiciary can construct a useful remedy, not how favorably that remedy compares with cures that could be fashioned by another branch." ${ }^{51}$ Although an injury is clearly redressable by the judiciary, it is still possible that another branch would be better equipped to fashion a remedy. " $[R]$ edressability is irrelevant to separation of powers. ${ }^{n 2}$

${ }^{48}$ Both the majority and the minority in Flast v. Cohen, 392 U.S. 83 (1968), have criticized the constitutional linkage to separation of powers in a standing context. Compare id. at 100 ("The question [of standing] does not, by its own force, raise separation of powers problems ....”) with id. at 130 (Harlan, J., dissenting) (explaining that even though certain actions "might well alter the allocation of authority among the three branches of the Federal Government," such actions are "within the jurisdiction conferred upon the federal courts"); see also Steven $M$. Kahaner, Separation of Powers and the Standing Doctrine: The Unwarranted Use of Judicial Restraint, 56 GEO. WASH. L. REV. 1074, 1076 (1988) (noting that the inclusion of separation of powers concerns into Article III "effectively preclude[s] legitimate claims from being addressed"); Logan, supra note 23, at 82 (arguing that prudential limits are the "preferable ground for decision" when considering separation of powers); Nichol, supra note 33, at 642 (explaining how separation of powers principles are at odds with Article III); Richard J. Pierce, Jr., Lujan v. Defenders of Wildlife: Standing as a Judicially Imposed Limit on Legislative Power, 42 DUKE L.J. 1170, 1187-88 (1993) (noting that inclusion of separation of powers concerns into Article III is unfortunate because it illustrates how the Court is not concerned with the proper standing questions); Poisner, supra note 25 (arguing that Article III standing is an inappropriate way to achieve the goals of separation of powers).

${ }^{49}$ See supra text accompanying note 42 (giving the three-pronged test).

${ }^{30}$ See Roseborough, supra note 41, at 1029 ("The separation-of-powers analysis . . . fails to support the . . . conclusion that the Article III standing requirements were not satisfied.").

${ }^{51}$ Nichol, supra note 33 , at 647 n.63.

${ }^{52} \mathrm{Id}$. at 647. 
Consequently, when courts link separation of powers to the constitutional inquiry, distortion and confusion arise. Again, a numerical hypothetical best elucidates the distortion that can occur. Assume that the redressability requirement is arbitrarily labelled as fifty. A litigant possessing redressability of sixty will easily satisfy constitutional muster. A court may still wish to prevent this litigant from obtaining judicial access due to a separation of powers concern. Even though the judiciary can adequately redress the litigant's injury, as is demonstrated by the litigant's redressability of sixty, the court may feel that the remedy may be more appropriately fashioned by another branch. For example, it may feel that the executive branch may be the more suitable choice. ${ }^{53}$ When the Court denies standing on a constitutional basis, it must point to one of three prongs. By identifying a specific prong, such as redressability, ${ }^{54}$ as the reason for the denial of standing, even though the litigant surpassed the previous redressability level of fifty by ten points, the Court has increased redressability to sixty. This increase becomes a problem when a similarly situated future litigant satisfies the previous constitutional level ${ }^{55}$ but implicates no separation of powers problems. For example, the judiciary may be the most suitable choice for fashioning a remedy for the new litigant. ${ }^{56}$

${ }^{53}$ The doctrine of exhaustion of administrative remedies provides an example of such a choice, although not explicitly couched in the language of standing. Myers v. Bethlehem Shipbuilding Corp., 303 U.S. 41 (1938), is a case where "[t]he exhaustion doctrine is best exemplified." DAVID P. CURRIE, FEDERAL COURTS 72 (1982). In Myers, the plaintiff sued to enjoin the NLRB from hearing an unfair labor practice case, arguing that the challenged practices were beyond the Board's jurisdiction. See Myers, 303 U.S. at 46 . The Court dismissed, invoking "the long settled rule of judicial administration that no one is entitled to judicial relief ... until the prescribed administrative remedy has been exhausted." Id. at 50-51 (citations omitted).

Certainly, the Court could have fashioned a remedy which would have redressed the plaintiff. (The Court could have granted the injunction, prohibiting the NLRB from hearing the unfair labor practice claim.) It did not hear the plaintiff's case, though. The traditional justification behind the exhaustion doctrine is that the Court reasons that the executive branch and its administrative remedies would be a more appropriate recourse for the plaintiff. "The exhaustion doctrine is . . . an expression of executive and administrative autonomy." McKart v. United States, 395 U.S. 185, 194 (1969) (quoting LOUIS L. JAFFE, JUDICIAL CONIROL OF ADMINISTRATIVE ACTION 425 (1965)). Consequently, separation of powers concerns kept the plaintiff out of court.

${ }^{54}$ The Court could just as easily decide to deny standing due to one of the other constitutional prongs.

${ }^{55}$ Such a litigant may possess a redressability of fifty-five.

${ }^{56}$ An example of such a litigant would be the plaintiff in Myers, if she had already exhausted all potential administrative remedies. This plaintiff possesses the required degree of redressability to satisfy the previous constitutional level and, due to the 
Nonetheless, the inclusion of the ill-fitted separation of powers analysis into the constitutional question distorts the redressability requirements. The second litigant would be denied judicial access, as he only possesses a redressability of fifty-five, whereas the new, distorted constitutional level would now be sixty. Future courts are denied the opportunity to grant standing to this litigant. ${ }^{57}$

There is little correlation between separation of powers analysis and the redressability prong of the Court's constitutional requirement. It is therefore inappropriate for the separation of powers issue to be included in the Article III analysis because such inclusion detracts from judicial power. Courts, unable to override the newly revised constitutional obstacle, will be prevented from evaluating the "countervailing considerations [which] may outweigh the concerns underlying the usual reluctance to exert judicial power when the plaintiff's claim to relief" implicates no separation of powers concerns. ${ }^{58}$

Additionally, the improper analysis of separation of powers unnecessarily detracts from congressional power. It is at least arguable that a congressional grant of standing will, of its own force, alleviate most worries about separation of powers due to the fact that Congress itself is the branch that authorizes the grant of standing. ${ }^{59}$ The typical argument for disallowing judicial access due to separation of powers concerns is that the particular problem at issue is one that is more appropriately addressed by the majoritarian Congress than by the counter-majoritarian judiciary. ${ }^{60}$ "Cong-

prior exhaustion of administrative remedies, implicates no separation of powers concerns.

${ }^{57}$ For examples of Supreme Court decisions denying future courts the chance to examine factors that mitigate separation of powers concerns, see infra notes 413-24, 439-58 and accompanying text.

${ }^{58}$ Warth v. Seldin, 422 U.S. 490, 500-01 (1975).

${ }^{59}$ The majority of the Court in Lujan would argue that even congressional grants of standing implicate separation of powers concerns when Congress authorizes suit against the Executive. See infra notes 508-18 and accompanying text.

${ }^{60}$ See Logan, supra note 23, at 47 (arguing that in a democracy, broad questions are best handled by elected representatives); see also Scalia, supra note 8 , at 894 (advocating the appropriateness of restricting "courts to their traditional undemocratic role of protecting individuals and minorities against impositions of the majority, and exclud[ing] them from the even more undemocratic role of prescribing how the other two branches should function in order to serve the interest of the majority itself" (emphasis omitted)); Sarah A. Robichaud, Note, Lujan v. National Wildlife Federation: The Supreme Court Tightens the Reins on Standing for Environmental Groups, 40 CATH. U. L. REV. 443, 473 (1991) (" $[1] \mathrm{t}$ is clear that the Supreme Court would prefer organizations seeking to challenge broad agency actions to request relief from Congress, as opposed to the judiciary."). 
ress' power to find facts, to determine the relationship between congeries of facts and to resolve questions of policy" makes the legislative branch very well-equipped to respond to broad issues. ${ }^{61}$ In the case of a congressional grant of standing, the majoritarian Congress has used its abilities and already decided to allow the courts to hear widespread grievances, thereby "mitigat[ing] the separation of powers concerns. ${ }^{n 62}$ Yet, the importation of separation of powers issues into the constitutional doctrine prevents even the majoritarian Congress from using its abilities to perform its lawmaking function. ${ }^{63}$ Even if Congress attempts to act, "the requirements of Art[icle] III remain...." A64 Avoidance of such importation is important because "it allows the democratic branch[] a role in deciding whether a judicial remedy is desirable for a question of broad social importance." 65 Therefore the inclusion of separation of powers concerns into the constitutional analysis infringes upon both congressional and judicial power.

Other potential justifications for standing-such as internationalism, federalism, and military deference-must also be separated from the constitutional analysis. The Court's three-pronged test is again particularly ill-suited to promote the furtherance of internationalism, ${ }^{66}$ military deference, or federalism. ${ }^{67}$

The Court's constitutional analysis, therefore, framed by the three-pronged test, most effectively guarantees the Court a clear

${ }^{61}$ Logan, supra note 23, at 61.

${ }^{62}$ PAUL M. BATOR ET AL., HART AND WEChSLER'S THE Federal COURTS AND THE FEDERAL SYSTEM 137 (3d ed. 1988).

${ }^{63}$ Professor Sunstein's recent article on Lujan further discusses the relationship between congressional grants of standing, separation of powers, and the Article III limits upon standing. See Cass R. Sunstein, What's Standing After Lujan? Of Citizen Suits, "Injuries," and Article III, 91 MICH. L. REV. 163 (1992). Sunstein argues that the limitations that the Lujan Court places upon Congress's ability to authorize suits have no "basis ... in constitutional text or history." Id. at 214.

${ }^{64}$ Simon v. Eastern Ky. Welfare Rights Org., 426 U.S. 26, 41 n.22 (1976) [hereinafter EKWRO].

${ }^{65}$ Logan, supra note 23, at 82. Indeed, Professor Logan argues not merely that the presence of Congress mitigates separation of powers worries, but rather that "separation of powers concerns [affirmatively] counsel the Court to defer to Congress' ability" to authorize standing. Id. at 61 .

${ }^{66}$ For a more detailed discussion of how the three-pronged test is not correlated to internationalism, see infra notes $376-77$ and accompanying text.

${ }^{67}$ See Nichol, supra note 6, at 101 (criticizing Supreme Court decisions that, in truth, deny standing on federalism concerns but, as the three-pronged test mandates, "purportedly dismiss[] the claim . . . because of an absence of injury"); Nichol, supra note 33 , at 650 (" $[\mathrm{T}]$ he expansion of standing's umbrella [into the area of federalism] will ill serve article III."). 
presentation of the issues. The three requirements are hardly selfdefining.

\section{B. The Constitutional Test}

\section{The Injury Limitation}

The Court, in articulating its injury limitation, requires that the injury satisfy four requirements. First, the injury must be to a "legally-protected interest." Second, the interest must be "particularized $^{n}$ to the plaintiff. ${ }^{69}$ Third, the injury must be likely to occur, not merely "speculative." ${ }^{\text {"0 }}$ Finally, the injury must be "imminent."

\section{a. Legally Protected Interests}

In order to establish standing, a plaintiff must have an injury to an interest that the courts will recognize. Courts recognize three classes of interests: constitutional, statutory, and judicially-created interests.

The Constitution, "of its own force, creates legally protected interests."72 The Court recognizes that every person has an interest in those rights provided directly by the Constitution. For example, the Court will grant standing for cases where a litigant claims an interest in the equal protection of the laws, ${ }^{73}$ or in the avoidance of a taking, ${ }^{74}$ or in the avoidance of the establishment

${ }^{68}$ Lujan, 112 S. Ct. at 2136. See generally 13 WRIGHT, supra note 12 , § 3531.4, at 420-23 (discussing what constitutes a legally protected interest); Gene R. Nichol, Jr., Injury and the Disintegration of Article III, 74 CAL. L. REv. 1915, 1929-39 (1986) (considering the concept of judicially cognizable interests).

${ }^{69}$ Lujan, 112 S. Ct. at 2136; see also Allen v. Wright, 468 U.S. 737, 755 (1984) (granting standing on a claim of injury due to racial discrimination only to those "who are personally denied equal treatment"); Warth v. Seldin, 422 U.S. 490, 508 (1975) (requiring an allegation of "particularized injury" to the plaintiff).

${ }^{70}$ City of Los Angeles v. Lyons, 461 U.S. 95, 109 (1983).

${ }^{71}$ Lujan, 112 S. Ct. at 2136 (quoting Whitmore v. Arkansas, 495 U.S. 149, 155 (1990)).

72 Nichol, supra note 6 , at 92 .

73 See Northeastern Fla. Contractors v. Jacksonville, 113 S. Ct. 2297, 2302-05 (1993) (reversing the Court of Appeals' denial of standing, and noting prior cases that granted standing due to an injury to a person's interest in equal protection of the laws); Baker v. Carr, 369 U.S. 186, 206-08 (1962) (granting standing on a similar analysis).

74 See Duke Power Co. v. Carolina Envtl. Study Group, Inc., 438 U.S. 59, 69, 72-81 (1978) (granting standing due in part to a person's interest in avoiding a taking without just compensation). 
of religion. ${ }^{75}$ The Constitution itself creates legally protectible interests that the Court must recognize as worthy of standing.

In addition, Congress, through statutes, can create interests beyond those that the Constitution protects. "Congress may enact statutes creating legal" interests which would not exist solely from the Constitution itself. ${ }^{76}$ Often, courts infer a congressionally mandated interest. In Trafficante $v$. Metropolitan Life Insurance $\mathrm{Co}^{77}$ two tenants of an apartment building sued the owner of the building for discrimination against nonwhites in the rental of apartments, alleging an injury to their interest in living in a desegregated community. ${ }^{78}$ The Court reasoned that although the Civil Rights Act of $1968^{79}$ did not explicitly protect the interest of "benefits from interracial associations," relevant provision of the statute a "generous construction" so as to "give vitality to the intent of eliminating racial discrimination in housing. ${ }^{\text {"1 }}$ Therefore, the Court "interpreted the ... provision[s] of the Civil Rights Act" as implicitly protecting such an interest. ${ }^{82}$

Lastly, the courts themselves can create interests when neither Congress nor the Constitution has identified a protected interest. ${ }^{83}$ Environmental interests are a relatively recent judicial phenomenon. Aesthetic, conservational, and recreational interests in the environment "would have been unthinkable in the 1940's." ${ }^{\text {"84 }}$ Yet today, the courts routinely acknowledge such interests. ${ }^{85}$ Numerous examples of other such court-created interests exist. ${ }^{86}$ As society's

${ }^{75}$ See Flast v. Cohen, 392 U.S. 83, 103-06 (1968) (granting standing due to a person's interest in avoiding the establishment of religion).

${ }^{76}$ Linda R.S. v. Richard D., 410 U.S. 614, 617 n.3 (1973). Justice Brennan has suggested that " $[t]$ he Framers of the Constitution, of course could, and did, exercise the same power" to create legal interests when framing the Constitution. Valley Forge Christian College v. Americans United for Separation of Church \& State, Inc., 454 U.S. 464, 492 n.2 (1982) (Brennan, J., dissenting).

7709 U.S. 205 (1972).

${ }^{78}$ See id., 409 U.S. at 207-08.

7942 U.S.C. $\$ \S 3600-3631$ (1988 \& Supp. III 1991).

${ }^{80}$ Trafficante, 409 U.S. at 210.

${ }^{81} I d$. at 212.

${ }^{82}$ Bullock, supra note 27 , at 615 .

${ }^{83}$ See Nichol, supra note 6 , at 89 (explaining that "the judiciary can interpret article III to develop a body of law that seeks to define" protected interests).

${ }^{84}$ Scalia, supra note 8 , at 886.

${ }^{85}$ See Lujan, 112 S. Ct. at 2137 (noting that observation of an animal, even for "aesthetic purposes," is a judicially protected interest); see also Sierra Club v. Morton, 405 U.S. 727, 734 (1972) (offering similar analysis).

${ }^{85}$ See Roe v. Wade, 410 U.S. 113, 124-25 (1973) (creating interest in obtaining a legal abortion); Eisenstadt v. Baird, 405 U.S. 438, 444-46 (1972) (creating interest 
need for protection of these areas grew, the Court became more willing to redefine its realm of legally protected interests. ${ }^{87}$ It makes sense that a court would be more willing to hear a litigant's case if the case is based on an interest which society has grown to cherish. For example, the reason environmental interests were not considered equally protected interests fifty years ago is because society, at that time, did not value the environment as much as it does now. Earlier courts would assume that a litigant bringing forth suit on behalf of an injury to such an interest could not possibly bring forth a zealous case. ${ }^{88}$ As values changed, however, "our society, and in turn, the judiciary, eventually recognized concern for the environment as a protectible interest." 89 In this manner, the courts often recognize interests which have not been recognized by Congress or the Constitution..$^{90}$

\section{b. Particularized Interests}

Even if a plaintiff alleges harm to a legally protected interest, there is no guarantee that she will have standing. "[T]he 'injury in fact' test requires more than an injury to a cognizable interest. It requires that the party seeking review be himself among the injured." The courts have required that the injury be particularized. The particularity requirement has two components: the injury must "affect the plaintiff in a personal and individual way."

in unmarried couple's use of contraception); Griswold v. Connecticut, 381 U.S. 479,481 (1965) (creating interest in married couple's use of contraception).

${ }^{87}$ One commentator has criticized this method of determining legally protected interests: "The problem with this requirement is that by the time society and then the courts decide that an issue is important and widespread enough to become a public value, many have already suffered injury." Bridget Klauber, See No Evil, Hear No Evil: The Federal Courts and the Silver Spring Monkeys, 63 U. CoLO. L. REV. 501, 509 (1992).

${ }^{88}$ See Nichol, supra note 6 , at 89 ("One can recall when the courts would have called a plaintiff claiming harm [to environmental interests] ... an interloper asserting no injury whatsoever.").

${ }^{89} \mathrm{Id}$. at 90; see also id. at 92 ("I have argued that the judicial recognition of [interests] is a process whereby public values are given cognizance in law.").

${ }^{90}$ Just as the courts can create interests as societal demands dictate, the courts will also eliminate interests consistent with societal demands. "During substantial periods of our history, for example, whites might well have considered themselves injured by a governmental decision that forced them to ride in the same railroad car with blacks." Id. at 90 . Today, because society no longer demands racial separation, the courts will not protect such an interest.

${ }^{91}$ Sierra Club v. Morton, 405 U.S. 727, 734-35 (1972).

${ }^{92}$ Lujan, 112 S. Ct. at 2136 n.1. 
The courts, in using the term individual, mean that the injury must occur specifically to the plaintiff. A litigant does not have standing to sue for an injury to someone else when that litigant herself has not suffered an injury. Plaintiffs must "show that they personally have been injured, not that injury has been suffered [entirely] by other" people who are not before the Court. ${ }^{93}$

${ }^{93}$ Warth v. Seldin, 422 U.S. 490,502 (1975). It is important to note that there is a difference between the constitutional requirement that the plaintiff herself be among the injured and the nonconstitutional bar to what the courts call "third party standing." If a plaintiff does not suffer an injury herself, she does not satisfy the Article III requirements and must therefore be denied standing due to constitutional limitations. Conversely, a plaintiff may be denied standing because she is a third party plaintiff although she does pass the constitutional injury threshold. Although she will bring a zealous enough case to satisfy the Article III limits, the third party plaintiff typically will be denied judicial access because the courts usually decide on a prudential basis that this plaintiff is not the "best suited to assert a particular claim." Gladstone, Realtors v. Village of Bellwood, 441 U.S. 91, 100 (1979). (Courts have discretion, naturally, to override the prudential barrier in certain circumstances, provided the litigant satisfies the constitutional requirement of a "sufficiently concrete interest' in the outcome of the issue in dispute." Powers v. Ohio, $111 \mathrm{~S}$. Ct. 1364, 1370 (1991)). A denial of standing to a third party plaintiff is a prudential limitation, not a constitutional one. The Court has been explicit about this distinction. See Warth, 422 U.S. at 499 ("[E]ven when the plaintiff has alleged injury sufficient to meet the 'case or controversy' requirement, this Court has held that the plaintiff . . . cannot rest his claim to relief on the . . . interests of third parties."); see also Duke Power Co. v. Carolina Envtl. Study Group, Inc., 438 U.S. 59, 80 (1978) (making note of the "prudential limitation on standing when rights of third parties are implicated ${ }^{n}$ ). Thus, when a court limits a plaintiff's third party standing, it does so prudentially-there is no doubt that the plaintiff has suffered an individual injury which passes constitutional muster. For articles attempting to give a general analytical framework for third party standing cases, see generally Henry P. Monaghan, Third Party Standing, 84 CoLUM. L. REV. 277 (1984); Robert A. Sedler, Standing to Assert Constitutional Jus Tertii in the Supreme Court, 71 YALE L.J. 599 (1962); Note, Standing to Assert Constitutional Jus Tertii, 88 HARV. L. REv. 423 (1974).

Similarly, overbreadth challenges, like third party standing cases, exist where the litigant mounts "a constitutional attack premised on the rights of parties not before the court." Monaghan, supra, at 282. In the interest of furthering the protection of First Amendment freedoms, overbreadth doctrine permits "a litigant whose own activities are unprotected [to] challenge a statute by showing that it substantially abridges the First Amendment rights of other parties not before the Court." Village of Schaumburg v. Citizens for a Better Env't, 444 U.S. 620, 634 (1980). It is important to understand, though, that before a litigant can bring an overbreadth challenge, she must satisfy the Article III injury requirements. An overbreadth litigant who receives standing does so not because she is "directly asserting the other person's rights to engage in protected conduct; rather [because] she is asserting her [own] right to be free from control by an invalid statute." Fletcher, supra note 6, at 244. The overbreadth litigant "has always had the right to . . . make a facial challenge to the constitutional sufficiency of the rule actually applied to him, irrespective of the privileged character of his own activity." Henry P. Monaghan, Overbreadth, 1981 SuP. CT. REV.1,3. Therefore, like third party standing cases, overbreadth cases satisfy the 
By personal, the courts mean that the plaintiff must have a "personal stake" in the outcome of the case. ${ }^{94}$ Whereas the individualized injury requirement focuses on whether the individual plaintiff has suffered an injury, the personal stake requirement focuses on how much injury this plaintiff must suffer in order to get standing. The Court does not typically require a large degree of personal stake to confer standing. "[A]n identifiable trifle is enough for standing." ${ }^{95}$ It is important to recognize, though, that the identifiable trifle requirement is relative to the rest of the population. The Court makes it clear that it will not grant standing to an individual, even if she suffers more injury than an identifiable trifle, if the injury that she suffers is "common to all members of the public. ${ }^{96}$ The personal stake requirement must be evaluated not in terms of whether the plaintiff suffers any injury at all, but rather in terms of whether the plaintiff suffers an injury which distinguishes her from the public at large. A person does not suffer enough of a personal injury to pass constitutional muster if she is merely a non-"Hohfeldian plaintiff," $"$ "that is, a plaintiff with no "interest other than seeing the law enforced according to its own terms. ${ }^{98}$ Clearly, incorrect resolution of the law is at least a trifle of an injury. ${ }^{99}$ The problem is that this injury is one that every person in the population shares. The Court will deny standing to such an injury.

In Baker $v . C a r r,{ }^{100}$ Tennessee voters challenged the validity of a state legislative apportionment scheme that had not been reapportioned since 1901 despite substantial population changes. ${ }^{101}$ The plaintiffs, who lived in the disfavored districts, asserted that they were denied equal protection of the laws guaranteed by the

Article III injury requirements. Courts can then grant or deny standing based upon prudential discretion.

94 Baker v. Carr, 369 U.S. 186, 204 (1962).

95 United States v. Students Challenging Regulatory Agency Procedures (SCRAP), 412 U.S. 669, 689 n.14 (1973) (quoting Kenneth C. Davis, Standing: Taxpayers and Others, 35 U. CHI. L. REv. 601, 613 (1968)).

${ }_{96}$ Ex parte Levitt, 302 U.S. 633, 634 (1937).

${ }^{97}$ Jaffe, supra note 45, at 1034-35.

${ }_{98}$ Chayes, supra note 6, at 11; see also Lujan, 112 S. Ct. at 2143 ("We have consistently held that a plaintiff ... claiming only harm to his and every citizen's interest in proper application of the Constitution and laws ... does not state an Article III case or controversy.").

${ }^{99}$ See Davis, supra note 95, at 613 (noting that the identifiable trifle may be the assertion of a "principle against the ... government").

${ }^{100} 369$ U.S. 186 (1962).

${ }^{101}$ See id. at 186-92. 
Fourteenth Amendment by the malapportionment of the state legislature. ${ }^{102}$ The Court held that the plaintiffs had suffered a personal injury distinct from the rest of the population's general interest in assuring that the state government does not violate the Constitution. ${ }^{103}$ Since the plaintiffs actually resided in the districts that suffered from the challenged apportionment, they had a "personal, if minuscule ... stake in the outcome." 104 By contrast, if plaintiffs outside the disfavored districts had challenged the plan of apportionment, they would almost definitely have been denied standing because their only interest would have been in the correct resolution of the law-not enough to distinguish them from the population as a whole. The injury that the real plaintiffs suffered was their placement in a "position of constitutionally unjustifiable inequality vis-à-vis" the rest of the population. ${ }^{105}$ Voters who were placed in this position suffered an injury distinct from other members of the public and therefore had standing.

A second area in which the Court disallows suits common to the entire population is in taxpayer suits. The theory behind such a suit is that the plaintiff suffers an injury larger than an identifiable trifle when the government deprives the plaintiff of the use of her tax dollars for purposes that violate the law. In Valley Forge Christian College v. Americans United for Separation of Church and State, ${ }^{106}$ the plaintiffs alleged that a conveyance of seventy-seven acres of surplus government-owned land to a Christian college violated the Establishment Clause of the First Amendment. ${ }^{107}$ The plaintiffs based standing on the fact that their tax dollars had been used for an unconstitutional purpose. ${ }^{108}$ The Court denied standing, explaining that because everyone pays taxes, a taxpayer plaintiff without more injury than a deprivation of tax money is really no different

${ }^{102}$ See id. at 193-94.

${ }^{103}$ See id. at 204-08.

${ }^{104}$ Chayes, supra note 6, at 11 .

${ }^{105}$ Baker, 369 U.S. at 207; see also Shaw v. Reno, 113 S. Ct. 2816, 2824 (1993) (noting that North Carolina residents stated a claim upon which relief can be granted when they challenged the state's allegedly unconstitutional redistricting legislation).

${ }^{106} 454$ U.S. 464 (1982).

${ }^{107}$ See id. at $468-69$.

${ }^{103} \mathrm{See} i \mathrm{i}$. at 469 ("The complaint asserted that each member 'would be deprived of the fair and constitutional use of his (her) tax dollar for constitutional purposes in violation of his (her) rights under the First Amendment . . . .' ); see also id. at 497-98 (Brennan, J., dissenting) ("The concept of taxpayer injury necessarily recognizes the continuing stake of the taxpayer in the disposition of the Treasury to which he has contributed his taxes ...."). 
than the rest of the population. ${ }^{109}$ The Court equated the taxpayer plaintiff to the non-Hohfeldian plaintiff. "[C]itizens generally [can]not establish standing simply by claiming an interest in governmental observance of the Constitution...."110 The assertion of an injury that everyone else suffers does not satisfy the constitutional requirement of personal stake.

While the personal injury requirement does mandate that the plaintiff suffer at least a trifle of an injury above the general population, ${ }^{111}$ there is no automatic lack of standing if many people suffer the same injury that the plaintiff suffers. " $[S]$ tanding is not to be denied simply because many people suffer the same injury." "112 Thus the Court seems to imply that if many people suffer the same injury, ${ }^{113}$ there is no constitutional bar, but if everyone suffers the same injury, there is a constitutional bar. ${ }^{114}$

${ }^{109}$ See id. at $476-82$.

${ }^{110} \mathrm{Id}$. at 482 . To complicate matters, there is an exception to this rule. Taxpayers, in a limited context, do have standing "solely on their status as taxpayers," even if they do not allege an injury that separates them from the rest of the population. See Flast v. Cohen, 392 U.S. 83, 85 (1968). The plaintiffs in Flast received standing because their taxpayer challenge was "made to an exercise by Congress of its power under Art. I, § 8, to spend for the general welfare." Id. at 103 . Since the grant of property in Valley Forge challenged an act of Congress's power under the Property Clause, Article IV, Section 3, Clause 2, and not under Article I, Section 8, the plaintiff was denied standing. See Valley Forge, 454 U.S. at 479-80; see also Schlesinger v. Reservists Comm. to Stop the War, 418 U.S. 208, 228 (1974) (denying standing because plaintiffs "did not challenge an enactment under Art. I, $\$ 8$, but rather the action of the Executive Branch"); United States v. Richardson, 418 U.S. 166, 175 (1974) (denying standing because plaintiff's challenge was "not addressed to the taxing or spending power, but to the statutes regulating the CIA"). Professor Chayes has characterized this distinction as follows: "As the law now stands, a taxpayer apparently has standing to stop the government from giving away money for religious purposes, but not to stop it from giving away property." Chayes, supra note 6, at 13.

${ }^{111}$ See supra notes 95-99 and accompanying text (explaining that a plaintiff must suffer an injury distinct from one that every person in the population shares in order to satisfy the injury requirement).

112 United States v. Students Challenging Regulatory Agency Procedures (SCRAP), 412 U.S. 669, 687 (1973); see also Lujan, 112 S. Ct. at 2143 (noting that standing is appropriate "where concrete injury has been suffered by many persons").

113 When many people suffer the same injury, the Court calls the injury a "generalized grievance." Logan, supra note 23, at 47; see also Valley Forge, 454 U.S. at 475.

${ }^{114}$ It is important to emphasize that there is a critical distinction between an injury suffered by the whole population and an injury that the Court calls a "generalized grievance." An injury suffered by all citizens, such as a denial of the "interest of all citizens in constitutional governance," does not pass constitutional muster. Valley Forge, 454 U.S. at 483 (quoting Schlesinger, 418 U.S. at 217). Such an injury "cannot alone satisfy the requirements of Art. III without draining those requirements of 


\section{c. Nonspeculative Injury}

Even if a plaintiff alleges a sufficiently particularized injury to a legally protected interest, the injury must be likely to occur, not merely speculative. In City of Los Angeles v. Lyons, ${ }^{115}$ four Los Angeles police officers stopped the plaintiff for a traffic code violation. After Lyons got out of his car, the police officers seized him and applied a chokehold that rendered him unconscious, "although Lyons offered no resistance or threat whatsoever."116 Lyons sued the officers for damages and sued for an injunction against the city, seeking to bar the use of chokeholds in the future, absent situations where the proposed victim "reasonably appears to be threatening the immediate use of deadly force. ${ }^{117}$ The Supreme Court discussed only the second claim and held that Lyons had no standing to bring such a suit. ${ }^{118}$ It reasoned that while the police clearly injured Lyons in the past, there was little likelihood that they would injure him again in the future. He did not have standing to enjoin the use of chokeholds in the future, the Court reasoned, because he had not established that he was likely to suffer injuries from them in the future. The Court explained:

That Lyons may have been illegally choked by the police [in the past], while presumably affording Lyons standing to claim damages against the individual officers ..., does nothing to establish a real and immediate threat that he would again be stopped for a traffic violation, or for any other offense, by ... officers who would illegally choke him into unconsciousness without any provocation or resistance on his part. ${ }^{119}$

meaning." Id. Conversely, when an individual alleges a generalized grievance-an injury shared by many but not suffered by the population as a whole-such an injury satisfies the Constitution's personal stake requirement. Courts will usually deny standing for such injuries, but they will explicitly do so for prudential reasons. See $i d$. at 474-75 ( $\left.{ }^{\text {[ }} \mathrm{E}\right] \mathrm{ven}$ when the plaintiff has alleged redressable injury sufficient to meet the requirements of Art. III, the Court has refrained from adjudicating ... 'generalized grievances' . . . ."); Gladstone, Realtors v. Village of Bellwood, 441 U.S. 91, 99-100 (1979) ("Even when a case falls within these constitutional boundaries, a plaintiff may still lack standing under the prudential principles by which the judiciary seeks to avoid deciding [a generalized grievance]."); Duke Power Co. v. Carolina Envtl. Study Group, Inc., 438 U.S. 59, 80 (1978) (denying standing due to "prudential concerns" about hearing "generalized grievance[s]").

115461 U.S. 95 (1983).

${ }^{116} I d$. at 97.

${ }^{11 \%} I d$. at 98 (quoting plaintiff's complaint).

${ }^{118}$ See id. at 105.

${ }^{119} \mathrm{Id}$. 
The Court will not grant standing to such an injury that is "no more than speculation. 120

\section{d. Imminent Injury}

Even if a plaintiff's injury to a protected interest is both particularized and nonspeculative, the actual occurrence of the injury must be imminent. ${ }^{121}$ In Coral Construction Co. v. King County, ${ }^{122}$ the defendant county preferentially granted contracts and subcontracts to businesses owned by either minorities or women. ${ }^{123}$ The plaintiff, a non-minority general contractor, alleged that King County's practice violated the Equal Protection Clause of the Fourteenth Amendment. ${ }^{124}$ The plaintiff sought an injunction of the defendant's preferential treatment, claiming an injury to its economic interests through loss of future bids. ${ }^{125}$

The court first reasoned that the plaintiff's future injury was not speculative. "It is highly probable that Coral Construction will again bid on work let by King County" and thereby suffer injury when their bid is preferentially denied. ${ }^{126}$ The court continued, stating that " $[t]$ his alone, however, is insufficient to confer standing upon Coral Construction. ${ }^{n 27}$ The plaintiffs must not only allege highly

${ }^{120}$ Id. at 108; see also Rizzo v. Goode, 423 U.S. 362, 372 (1976) (holding that standing must be denied due to speculative nature of injury); O'Shea v. Littleton, 414 U.S. 488, 497 (1974) (denying standing because plaintiff's allegations of future illegal conduct took the Court "into the area of speculation and conjecture"). In Roe v. Wade, 410 U.S. 113 (1973), the Court, while granting standing to a single female and ultimately deciding that she did have a protected interest in the right to abortion, denied standing to a married couple who likewise alleged an injury to their right to abortion. See id. at 128. The Does, a childless couple, claimed a personal stake in the right to an abortion. See id. at 127. Mrs. Doe's physician had advised her to avoid pregnancy for health reasons. See id. The Does claimed that Mrs. Doe might become pregnant due to possible failure of her contraception. See id. at 128. If this occurred, she might need an abortion to avoid the health impairment that would arise from a pregnancy. The Court denied standing due to the speculative nature of the injury. See id. "Their alleged injury rests on possible future contraceptive failure, possible future pregnancy, .... and possible future impairment of health. Any one or more of these several possibilities may not take place and all may not combine." Id. at 128.

${ }^{121}$ See Lujan, 112 S. Ct. at 2136 (noting that injury must be imminent); Whitmore v. Arkansas, 495 U.S. 149, 155 (1990) (same); City of Los Angeles v. Lyons, 461 U.S. 95, 102 (1983) (same).

122941 F.2d 910 (9th Cir. 1991), cert. denied, 112 S. Ct. 875 (1992).

${ }^{123}$ See id. at 914.

${ }^{124}$ See id. at 914-15.

125 See id. at 929 .

${ }^{126}$ Id. at $929-30$ (emphasis added).

${ }^{127}$ Id. at 930. 
probable injury, but they "must also demonstrate imminent... injury." ${ }^{128}$ The court ultimately granted standing, noting that the plaintiff suffers injury "every time the company simply places a bid." 129 The point of this case, however, is that the court explicitly enunciates the independent requirement of imminence. Presumably, by acknowledging that the plaintiff suffers injury whenever it bids, the court is assuming that the plaintiff will bid imminently, and therefore suffer an imminent injury.

\section{Causation}

After satisfying the injury prong, the plaintiff must then satisfy the causation prong of the constitutional standing test. In most cases, the causation inquiry will be identical to the redressability inquiry, which is the third prong. ${ }^{130}$ Certain sources, however, explicitly distinguish the two requirements. ${ }^{131}$ To the extent that a difference does exist, "it is that the [causation inquiry] examines the causal connection between the assertedly unlawful conduct and the alleged injury, whereas the [redressability inquiry] examines the causal connection between the alleged injury and the judicial relief requested." 132 The causation question asks whether the challenged conduct causes the injury. The redressability question asks whether the requested relief to the challenged conduct will redress the injury. In most cases, the requested relief amounts to the cessation of the challenged conduct ${ }^{133}$ and therefore renders answers to the two questions identical. ${ }^{134}$ In rare cases, however,

${ }^{128} \mathrm{Id}$.

${ }^{129} \mathrm{Id}$.

${ }^{130}$ See Haitian Refugee Ctr. v. Gracey, 809 F.2d 794, 801 (D.C. Cir. 1987) ("The 'traceability' and 'redressability' requirements are closely related."); National Wildlife Fed'n v. Babbitt, 835 F. Supp. 654, 663 (D.D.C. 1993) (stating that "the causation and redressability prongs of standing are often replicated"); CHARLES A. WRIGHT, LAW OF FEDERAL COURTS: CASES AND MATERIALS, $\$ 13$, at 68 n.43 (4th ed. 1983) (calling the two inquiries "two facets of a single causation requirement"); Klauber, supra note 87, at 506 (explaining that some courts have "combined the causation and redressability into one requirement").

${ }^{131}$ See Nichol, supra note 6, at $71 \mathrm{n} .16$ ("I have argued . . . that . . . the causation and redressability requirements are distinct." (citation omitted)).

${ }^{132}$ Allen v. Wright, 468 U.S. 737, 753 n.19 (1984).

${ }^{133}$ For example, in Lujan, the challenged conduct was the lack of consultation and the requested remedy was the undertaking of consultation. See Lujan, $112 \mathrm{~S}$. Ct. at $2140-42$.

${ }^{134}$ See New York v. Thomas, 613 F. Supp. 1472, 1481 (D.D.C. 1985) ("[Causation] and redressability 'are inseparable in the present case because the relief plaintiffs seek is an [injunction] compelling the [defendant] to end the very inaction which is the 
the requested relief seeks more than the cessation of the challenged conduct. In such cases, it is possible that the requested relief will redress an injury that was not caused by the defendant's conduct. The case of Allen $v$. Wright ${ }^{135}$ provides such an example.

In Allen, the plaintiffs alleged that the Internal Revenue Service had "not adopted sufficient standards and procedures to fulfill its obligation to deny tax-exempt status to racially discriminatory private schools." ${ }^{136}$ The plaintiffs, parents of black public school children, argued that the IRS, by exempting certain racially discriminatory private schools from having to pay taxes, interfered with the ability of the plaintiffs' children to attend racially integrated public schools. ${ }^{137}$ The plaintiffs alleged that the IRS's grant caused an underrepresentation of whites, and, consequently, a lack of desegregation, in the public schools that their children attended. ${ }^{138}$ The Court denied standing, holding that the plaintiffs failed to satisfy the constitutional requirement of causation. ${ }^{139}$ The Court reasoned that the line of causation between the IRS's allegedly illegal grant of tax exemptions to racially discriminatory private schools and the lack of desegregation of plaintiffs' schools is "attenuated at best."140 The plaintiffs did not show that withdrawal of the tax-exempt status from the discriminatory private schools would cause a "parent of a child attending such a private school [to] decide to transfer the child to public school as a result of any changes ... made by the private school once it was threatened with loss of tax-exempt status." ${ }^{141}$ Consequently, the plaintiffs did not show that the IRS's grant caused the injury of effectively segregated public schools.

cause of plaintiffs' injuries." (citation omitted)).

135468 U.S. 737 (1984).

${ }^{136} I d$. at 737.

${ }^{137}$ See id. at 744-45.

138 The causation argument that the plaintiffs tried to make "was simple." Nichol, supra note 33 , at 640 n.26. Dean Nichol described the causation as follows:

[T]ax-exempt status makes private schools economically more attractive. The IRS procedures allow private schools to retain that status while practicing racial discrimination. The IRS procedures thereby foster and encourage private discriminatory schools. The formation and expansion of these schools in plaintiffs' school districts harms the process of desegregation.

Id.

139 See Allen, 468 U.S. at 753.

${ }^{140} \mathrm{Id}$. at 757 .

${ }^{141} \mathrm{Id}$. at 758 . 
Similarly, if the relief requested were limited to the cessation of the illegal conduct, one could use the above analysis to conclude that the plaintiffs could not prove that the remedy would redress the injury of effectively segregated public schools. ${ }^{142}$ If the plaintiffs had requested a remedy, however, that went "well beyond the violation of law alleged," it might then have been possible to find that the remedy would redress the injury. ${ }^{143}$ For example, if the plaintiffs had requested an injunction requiring the IRS not only to deny tax-exempt status to racially discriminatory private schools, but also to penalize private schools that did not cease their discriminatory behavior, it is far more likely that the requested remedy would redress the injury. Nonetheless, "[e]ven if the ... [plaintiffs'] request might have a substantial effect on the desegregation of public schools," thereby satisfying the redressability requirement, the plaintiffs would still be unable to prove that the IRS's illegal activity caused the injury of effectively segregated public schools. ${ }^{144}$ Therefore, the plaintiffs were denied standing because they could not satisfy the second constitutional requirement.

In most cases, however, the causation and redressability questions merge. Indeed the Supreme Court has often explicitly equated the two requirements: "The more difficult step in the standing inquiry is establishing that these injuries 'fairly can be traced to the challenged action of the defendant,' ... or put otherwise, ... that the exercise of the Court's remedial powers would redress the claimed injuries." 145

\section{Redressability}

The Court has failed to give a precise definition of redressability ${ }^{146}$ by varying the degree of specificity necessary to satisfy Article III. The standard has changed from requiring the plaintiff

${ }^{142}$ Even if the Court granted such a remedy by enjoining the IRS from exempting discriminatory schools, the plaintiffs still would not be able to show that the white parents of the private school children would move their children from the private schools to the public schools.

I4s Id. at 753 n.19.

${ }^{144} I d$.

${ }^{145}$ Duke Power Co. v. Carolina Envtl. Study Group, Inc., 438 U.S. 59, 74 (1978) (emphasis added) (quoting Simon v. Eastern Ky. Welfare Rights Org., 426 U.S. 26, 41 (1976)).

${ }^{146}$ See Nichol, supra note 33, at 650 ("The redressability standard has been so aggressively manipulated that one would be hard-pressed to define it."). 
to show that the "prospective relief will remove the harm," ${ }^{\text {147 }}$ to requiring the plaintiff to show a "substantial likelihood"148 that the relief will redress the injury, to requiring the plaintiff to only show that the injury is "likely to be redressed." 149

It is possible that the difficulty in defining redressability arises from the fact that the likelihood of redressability often varies with the likelihood that the injury would occur again even if the requested relief were not granted. For example, in O'Shea $v$. Littleton, ${ }^{150}$ nineteen individuals tried to enjoin the defendants, a magistrate and a circuit court judge, from applying the law in violation of the Fourteenth Amendment. ${ }^{151}$ The defendants had engaged in "illegal bond-setting, sentencing, and jury-fee practices ${ }^{\prime 152}$ in a racially discriminatory manner in the past. The plaintiffs, alleging an injury to their right to be free from future judicial discrimination on account of race, sought an injunction against such future conduct. It is clear that the request, if granted, would have redressed the injury. ${ }^{153}$ Yet the Court denied standing, doubting whether the injunction could provide "adequate ... relief." 154 The primary basis for this denial of standing was the fact that even without judicial intervention, there was only a small likelihood that the plaintiffs "will again be arrested for and charged with violations of the criminal law and will again be subjected to bond proceedings, trial, or sentencing. ${ }^{n 155}$ The Court denied standing not due to a lack of redressability but rather because it felt the remedy was not needed. ${ }^{156}$

${ }^{147}$ EKWRO, 426 U.S. at 45 (emphasis added) (quoting Warth v. Seldin, 422 U.S. 490,505 (1975)).

${ }^{148}$ Duke Power, 438 U.S. at 75 n.20.

${ }^{149}$ Arlington Heights v. Metropolitan Hous. Dev. Corp., 429 U.S. 252, 262 (1977) (quoting EKWRO, 426 U.S. at 38).

${ }^{150} 414$ U.S. 488 (1974).

151 See id. at 490 .

${ }^{152} I d$. at 495 .

${ }^{153}$ An injunction would presumably have prevented future racial discrimination by the defendants.

${ }^{154}$ O'Shea, 414 U.S. at 499.

${ }^{155} I d$. at 496.

${ }^{156}$ A numerical example helps to clarify how this works. Assume, for the sake of argument, that the requested relief in $O$ 'Shea would lead to a $100 \%$ chance that the injury would be redressed. The plaintiffs are assured that the defendants will no longer racially discriminate. The Court denied standing because, even without the remedy, there was already a $90 \%$ chance that the injury would not occur. The fact that the remedy only improves the chances of redressability by $10 \%$ suggests that the judicial remedy was not really needed in the first place. 
Conversely, in Regents of the University of Califormia v. Bakke, ${ }^{157}$ Alan Bakke applied to medical school and was rejected. The university openly employed a special admissions program that reserved sixteen of one hundred seats for minority students. Bakke challenged the program under the Fourteenth Amendment and alleged an injury to his medical career. Despite the fact that Bakke could not guarantee that he would have been admitted "even absent any preference for minorities, ${ }^{158}$ the Court awarded standing. Instead of denying standing because the elimination of the program would not have assured Bakke's successful admission into medical school, the Court granted standing because the elimination of the program gave him the chance to "compete for all 100 places." The Court allowed Bakke's suit not because of guaranteed redressability, but because the remedy increased his chances of alleviating the injury. ${ }^{160}$

Ultimately, redressability is not an absolute standard. This may give rise to the judicial inconsistency in definition. Nonetheless, the

${ }^{157} 438$ U.S. 265 (1978).

158 BATOR, supra note 62, at 130; see also Nichol, supra note 6, at 81 (questioning "Alan Bakke's ability to prove that he would have been admitted to medical school absent the contested ... program").

${ }^{159}$ Bakke, 438 U.S. at 281 n.14. The Supreme Court in Northeastern Fla. Contractors v. Jacksonville, 113 S. Ct. 2297 (1993), has recently reaffirmed the type of standing granted in Bakke, even though there is no guaranteed redressability:

When the government erects a barrier that makes it more difficult for members of one group to obtain a benefit than it is for members of another group, a member of the former group seeking to challenge the barrier need not allege that he would have obtained the benefit but for the barrier in order to establish standing.

Id. at 2303 ,

${ }^{160}$ Whereas the possibility that the requested relief in $O^{\prime}$ Shea was hypothetically $100 \%$, see supra note 156 and accompanying text, the possibility that eliminating the contested program in Bakke would result in Bakke's admission into medical school is rather speculative. Assume, for argument's sake, that his chances of admission, if the Court had enjoined the program, were $70 \%$. The Court granted Bakke (and his 70\% chance of redressability) standing, but denied the plaintiffs in O'Shea (and their 100\% chance of redressability) standing. The reason is that without judicial relief, the O'Shea plaintiffs already had a $90 \%$ chance of avoiding the injury. Meanwhile, Bakke, without judicial relief had a much smaller chance of avoiding the injury. (Before bringing suit, he had already applied twice and was rejected both times. See Bakke, 438 U.S. at 276-77.) Assume that his chance of admission was $30 \%$ without judicial intervention. The Court then appears to have based its redressability determination upon the fact that it helped Bakke's chances of avoiding the injury by $40 \%$, and thus granted standing even though the Court could not guarantee redressability. The requested relief would only have helped the O'Shea plaintiffs by $10 \%$, thus the Court denied standing even though it could guarantee redressability. 
requirement becomes more sensible when one thinks of it not in terms of whether the requested remedy will definitely cure the injury (as in O'Shea, where the Court denied standing), but rather in terms of whether the requested remedy will greatly improve the chances of redressing the injury (as in Bakke, where the Court granted standing).

\section{The IMPORTATION OF PRUDENTIAL LIMTtations}

This Comment has argued that the purpose of constitutional limitations is to guarantee that the litigants are sufficiently adverse, which in turn assures the proper sharpening of the issues before the Court. ${ }^{161}$ Since the Court first enunciated the requirement of a personal stake to assure the "concrete adverseness which sharpens the presentation of issues upon which the court so largely depends" in $1962,{ }^{162}$ the Court has quoted this constitutional standard with approval in approximately twenty-five majority opinions. ${ }^{163}$ It is quite dangerous, however, to use the frequency of quotation "as a basis for predicting what the Court will do about" its constitutional analysis. ${ }^{164}$ Indeed the Court consistently manipulates its threepronged test of constitutionality-which should be used only to assure zealous advocacy-in order to import considerations which should be completely independent of the constitutional requirements. This inclusion of other factors into the constitutional analysis results in an inconsistent constitutional doctrine.

\section{A. Historical Manipulation}

\section{Injury}

Commentators do not hesitate to point out the arbitrariness of the injury-in-fact test. ${ }^{165}$ The problems with this test are evident in many of the individual requirements.

\footnotetext{
${ }^{161}$ See supra notes $34-46$ and accompanying text.

162 Baker v. Carr, 369 U.S. 186, 204 (1962).

${ }^{163}$ Search of LEXIS, Genfed library, US file (Oct. 29, 1993).

${ }^{164}$ DAvIS, supra note $6, \S 24: 18$, at 281.

165 Chayes, supra note 6 , at 19; see also Bullock, supra note 27, at 612 (noting that the Court's application of injury has "led to confusing and inconsistent results"); Nichol, supra note 6, at 78-79 ("TThe] injury standard has failed to provide a[n] . . objectively ascertainable method of measuring access to the federal courts.").
} 


\section{a. Inconsistent Interests}

A number of early Supreme Court standing decisions illustrate the "malleability of interest." 166 In Alabama Power Co. v. Ickes, ${ }^{167}$ the plaintiff, an Alabama electric power company, sued the Federal Emergency Administrator of Public Works. ${ }^{168}$ The Administrator had been making loans and grants to Alabama municipalities that used the money to construct power plants that competed with the plaintiff's plant. ${ }^{169}$ The plaintiff alleged that this activity infringed upon its legally protected interest to be free from competition supported by government activity. ${ }^{170}$ The Court, however, held that the plaintiff "has no such interest" and could not enjoin the "lawful, albeit destructive, competition with" the Alabama municipalities. ${ }^{171}$ "What [the plaintiff] anticipates ... is damage to something it does not possess-namely, a right to be immune from lawful ... competition." 172 In Federal Communications Commission v. Sanders Brothers Radio Station, ${ }^{173}$ however, the Court granted standing to a plaintiff with an identical interest. When the FCC awarded a broadcast license to a private competitor, the plaintiff, a radio station already possessing a license, sued to enjoin the activity. The plaintiff alleged an injury to its interest in freedom from government-supported competition. ${ }^{174}$ The Court held that this was enough of a legally "sufficient interest" to allow the suit to proceed. ${ }^{175}$

The radio station and the power company both alleged an interest in freedom from competition that was supported by government activity. Yet the Court protected the radio station's interest while rejecting the power company's interest. It is difficult to distinguish these cases because the interests in question were singular. Either common law, congressional mandate, or the Constitution protects an interest or it does not. The Court is importing factors into its analysis beyond the appropriate question

\footnotetext{
16613 WRIGHT, supra note $12, \S 3531.4$, at 423 .

${ }^{267} 302$ U.S. 464 (1938).

${ }^{163}$ See id. at 476.

${ }^{169}$ See id.

170 See id. at 475 .

171 Id. at 478 .

172 Id. at 480 .

173309 U.S. 470 (1940).

${ }^{174}$ See id. at 471-73.

175 Id. at 477 .
} 
of whether or not freedom from competition is legally protected by one of these three sources. ${ }^{176}$

One possible external factor that the Court included into its constitutional analysis is what should be the prudential concern of federalism. In Sanders Brothers, the party that could have been potentially injured from a suit which enjoined competition was the Telegraph Herald, a private newspaper company that wanted to start a radio station. ${ }^{177}$ In Alabama Power, however, the potentially injured parties were the Alabama municipalities that wished to operate power plants. ${ }^{178}$ Indeed, the Court stressed that the biggest problem with the plaintiff's case in Alabama Power was not that the plaintiff was attempting to enjoin mere competition, but rather "municipal competition." 179 It is quite possible that the Court in Alabama Power denied the plaintiff standing because it did not wish to infringe upon the state of Alabama's rights. ${ }^{180}$ It is completely appropriate for the Court to consider federalism concerns in its standing analysis. ${ }^{181}$ It should not, however, consider federalism in its constitutional analysis. ${ }^{182}$ Such a concern must be properly considered as a prudential limitation. ${ }^{183}$ By importing federalism concerns into the constitutional consideration of whether an interest is legally protected, the Court distorts the relevant question of whether freedom from competition is a legally protected interest.

A comparison of Trafficante v. Metropolitan Life Insurance Co. ${ }^{184}$ with Warth v. Seldin ${ }^{185}$ provides another example in which the Court examined factors other than the appropriate constitutional

${ }^{176}$ There is no other way that the Court could conclude in similar cases that competition is not legally recognized as a sufficient interest in 1938 but then suddenly is legally recognized in 1940.

177 See Sanders Bros., 309 U.S. at 471.

${ }^{178}$ See Alabama Power, 302 U.S. at 473.

${ }^{179} \mathrm{Id}$. at 480 (emphasis added).

${ }^{180}$ The Court is concerned with preserving the power of the state's municipalities. See id. (explaining that if the power company should lose business "by the operations of ... municipalities, it will be by lawful competition" (emphasis added)).

${ }^{181}$ See infra text accompanying note 392 (discussing why federalism may be appropriately considered as part of the prudential analysis).

${ }_{182}$ See supra note 67 and accompanying text.

${ }^{188}$ If federalism is instead included in the constitutional analysis, which is beyond the reach of the courts and Congress, then future courts and Congress will be deprived of their protected discretion to decide whether or not the prudential concern of federalism is implicated.

${ }^{184} 409$ U.S. 205 (1972).

${ }^{185} 422$ U.S. 490 (1975). 
question of whether or not an interest is legally protected. In Trafficante, the Court granted standing to two tenants who wished to sue their landlord. ${ }^{186}$ The tenants alleged that their landlord's discriminatory conduct cost them the "benefits of living in an integrated community. ${ }^{187}$ Conversely, a plaintiff in Warth alleged deprivation of an identical interest and did not receive standing. The plaintiff, Metro-Act, claimed that the defendant municipality, Penfield, had a zoning ordinance that excluded persons of low income from residing in the town in violation of the Fourteenth Amendment. ${ }^{188}$ The plaintiff was a nonprofit corporation whose purpose was to try "to alleviate the general housing shortage for low and moderate income persons" in the area. ${ }^{189}$ Metro-Act had members who already lived within Penfield and members who were forced to live outside of Penfield due to the restrictive ordinance. ${ }^{190}$ The Court denied standing to those members who lived outside Penfield due to lack of causation. ${ }^{191}$ Yet it also denied standing to those members who already lived in Penfield. ${ }^{192}$ These members, exactly like the plaintiffs in Trafficante, alleged an injury to their interest in "the benefits of living in a racially and ethnically integrated community." 193 The Court, however, recognized the interest in Trafficante but failed to recognize the interest in Warth.

The most plausible explanation for this discrepancy is that the Court imported what should be a prudential concern-separation of powers-into its constitutional analysis. ${ }^{194}$ The Trafficante plaintiffs received standing because they based their claim upon the Fair Housing Act, which statutorily granted standing. ${ }^{195}$ Such "[a]

${ }^{186}$ See Trafficante, 409 U.S. at 212.

${ }^{187} I d$. at 208; see also supra note 78 and accompanying text (describing the cognizable interest of the Trafficante plaintiffs in living in a desegregated community).

${ }^{188}$ See Warth, 422 U.S. at 493.

189 Id. at 494.

190 See id. at 512.

191 See id. at 506-07. These members could not prove that even if the zoning ordinances were removed, third party contractors would be willing to build low income housing. See id. at 506 (explaining that the members' "inability to reside in Penfield is the consequence of the economics of the area housing market, rather than of respondents' [the town of Penfield and its Zoning, Planning, and Town Boards'] assertedly illegal acts”).

192 See id. at 514.

193 Id. at 512.

194 For a discussion of why the use of separation of powers concerns is inappropriate for Article III analysis, see supra notes 47-65 and accompanying text.

${ }^{195}$ See Trafficante, 409 U.S. at 209-12. 
statutory grant of standing does indeed alleviate concerns over separation of powers. ${ }^{196}$ Conversely, the Warth plaintiffs were denied standing because their claim was based upon constitutional grounds, not statutory grounds. Indeed, the Court in Warth explicitly distinguished Trafficante, in which standing was granted because of the Civil Rights Act. As the Warth Court stated: "In this [the existence of a statutory basis for standing], we think, lies the critical distinction between Trafficante and the situation here. ${ }^{\text {197 }}$

Although "there is absolutely no basis for making the Article III inquiry turn on the source of the asserted right, ${ }^{n 198}$ the Court in Warth appears to have focused its inquiry on the source of the standing interest. However, just as federalism concerns should clearly be separated from the constitutional requirement of a legally protected interest, so should separation of powers concerns be separated. ${ }^{199}$ As one commentator asked with respect to the disparity between the Court's holdings in Trafficante and Warth: "[B]ut is article III analysis well served when injury to the same interest is judicially cognizable on one occasion but not on the next?"200

\section{b. Inconsistent Particularity}

The requirement of a "particularized injury" has also proven to be "an elusive foundation." ${ }^{201}$ In Baker v. Carr, ${ }^{202}$ the plaintiffs challenged Tennessee's failure to reapportion the seats in the state legislature after a substantial growth and redistribution of the state population. $^{203}$ The plaintiffs, residents of disadvantaged districts,

${ }^{196}$ Nichol, supra note 33, at 654; cf. Fletcher, supra note 6, at 254 (citing cases where the Court would not "have granted standing if Congress had not done so by statute").

${ }^{197}$ Warth, 422 U.S. at 513. The reason that a grant of standing based upon the Constitution implicates separation of powers concerns more than a congressional grant is that a constitutional grant requires the counter-majoritarian judiciary, and its tendency to "enforc[e] the political prejudices of [its] own class," to decide who should have judicial access. Scalia, supra note 8 , at 896 . Conversely, a statutory grant of standing allows the majoritarian Congress the opportunity to decide the question of judicial access. See supra notes $59-65$ and accompanying text.

${ }^{198}$ Lujan v. Defenders of Wildlife, 112 S. Ct. 2130, 2144 (1992).

${ }^{199}$ Also like federalism concerns, separation of powers concerns should be appropriately considered as a prudential worry. See infra notes 393-94 and accompanying text.

200 Nichol, supra note 33, at 654 .

201 Nichol, supra note 6 , at 71 .

202369 U.S. 186 (1962).

203 See supra notes $100-05$ and accompanying text. 
alleged an injury to their right "to a vote free of arbitrary impairment." ${ }^{204}$ They based their claim upon the Equal Protection Clause of the Fourteenth Amendment. ${ }^{205}$ The Court granted standing, holding that the plaintiffs had alleged an adequate personal stake to distinguish themselves from the rest of the population. ${ }^{206}$ Since it is true that only a "trifle" of an injury is needed to separate a deserving litigant from the public at large, ${ }^{207}$ the Court held that the injury that one suffers from vote dilution due to the malapportionment of legislative districts is enough to confer standing. ${ }^{208}$ Nonetheless, it is difficult to argue that the plaintiffs' injury was far removed from that of the population in general. ${ }^{209}$ As Professor Chayes argues, there is not "much difference between those who brought [the] suit and the nonHohfeldian plaintiff." 210

In Schlesinger v. Reservists Committee to Stop the War, ${ }^{211}$ the Court denied plaintiffs standing to sue due to their lack of a personal stake. ${ }^{212}$ Basing their claim upon the Incompatibility Clause of the Constitution, ${ }^{213}$ the plaintiffs asserted that certain members of Congress were simultaneously serving in the Reserve. ${ }^{214}$ The plaintiffs asked the Court to require the Secretary of Defense to strike these members of Congress from the Reserve. ${ }^{215}$ The Court denied standing, holding that the plaintiffs did not allege a "personal stake" separate from the injury that "all citizens share." ${ }^{216}$ As the dissent explained, however, "[t]he specific interest which [the plaintiffs] ... asserted . . . is certainly not a 'general interest common to all members of the public.'217

204 Baker, 369 U.S. at 208.

205 See id. at $207-08$.

206 See id. at 208.

207 See Davis, supra note 95, at 613.

${ }^{208}$ See Baker, 369 U.S. at 237 (stating that malapportionment creates a "justiciable" cause of action under the Fourteenth Amendment).

${ }^{209}$ All members of the public have an interest in proper vote allocation. Arguably, the plaintiffs' interest is marginally greater because it is their vote which is diluted. ${ }_{210}$ Chayes, supra note 6 , at 11 . For a description of the non-Hohfeldian plaintiff, see supra notes $97-98$ and accompanying text.

211418 U.S. 208 (1974).

212 See id. at 220.

215 The Incompatibility Clause, U.S. CoNST. art. I, § 6, cl. 2, provides: “[N]o Person holding any Office under the United States, shall be a Member of either House during his Continuance in Office.

214 See Schlesinger, 418 U.S. at 210.

215 See id. at 211.

${ }^{216} \mathrm{Id}$. at $220-21$.

${ }^{217}$ Id. at 239 (Marshall, J., dissenting) (quoting Ex parte Levitt, 302 U.S. 633, 634 
The plaintiffs were not merely citizens who wanted the law enforced properly. Rather, they were members of the Reserve itself, and therefore they had an interest above and beyond that of the population at large. After all, "Reserve membership ... place[s] upon Members of Congress possible inconsistent obligations which might cause them to violate their duty faithfully to perform as reservists." 218 The plaintiffs, as reservists, surely had an interest beyond that of the common public in assuring that other Reserve members did not violate a duty to perform faithfully to the service. The plaintiffs had a legitimate stake in the avoidance of a conflict of interests by reservists who were also members of Congress and therefore subject to conflicting duties.

It is difficult to reconcile the holdings in Baker and Schlesinger. ${ }^{219}$ In Baker, the plaintiffs were marginally separable from the public, yet the Court acknowledged their possession of a personal stake. In Schlesinger, the plaintiffs were clearly separable from the public, yet the Court did not acknowledge a personal stake. Schlesinger begins to make more sense, however, when one considers that the case occurred during the Vietnam War. It is at least plausible that the military sector of the executive branch wanted members of Congress to remain in the Reserves so that the Executive could exert "influence" ${ }^{\text {"220 }}$ over these reservists. Particularly in times of war, the Supreme Court has been known to distort the law in order to show deference to the needs of the military. ${ }^{221}$

By considering military deference in its constitutional standing analysis, the Court artificially raises the level of the particularized injury required to satisfy constitutional requirements. Presumably, a plaintiff who barely satisfied the old constitutional level of

\section{(1937)).}

${ }^{218} I d$. at 212.

${ }^{219}$ See Nichol, supra note 33, at 655 n.108 ('[W] hy was the action in Schlesinger characterized as 'abstract,' while a reapportionment plaintiff's injury was deemed to be "concrete"?").

${ }^{220}$ Schlesinger, 418 U.S. at 212 (1974). The source of this executive influence would be 10 U.S.C. $\$ \S 672-675$ (1970), which describes the "President's power to call reservists to active duty without their consent." Schlesinger, 418 U.S. at 212 n.3; see also TRIBE, supra note 42, § 3-18, at 129 (acknowledging that "the presence of numerous reservists in the halls of Congress" enhances the continuation of "military-legislative connections").

${ }^{221}$ See Korematsu v. United States, 323 U.S. 214, 233-34 (1944) (Murphy, J., dissenting) ("In dealing with matters relating to the prosecution and progress of a war, we must accord great respect and consideration to the judgments of the military authorities who are on the scene and who have full knowledge of the military facts."). 
personal stake outlined in Baker could be denied standing if she did not meet the stricter Schlesinger level, even where military deference considerations were not implicated.

\section{c. Inconsistent Speculation}

In Rizzo v. Goode, ${ }^{222}$ the plaintiffs sued the Philadelphia police department, alleging that the department had violated their constitutional rights by failing to process adequately a series of complaints filed against various police officers. ${ }^{223}$ The district court granted an injunction affirmed by the Third Circuit, requiring the police commissioner to formalize directives for handling complaints. ${ }^{224}$ The Supreme Court reversed, denying standing on the grounds that "[p]ast exposure to illegal conduct does not in itself show a present case or controversy regarding injunctive relief . . . if unaccompanied by any continuing, present adverse effects." 225 Because plaintiffs had based their claim not on violations certain specific officers were likely to commit in the future, but rather on what an "unnamed minority of policemen might do to [the plaintiffs] in the future, "the harm was found to be too hypothetical, speculative and conjectural. ${ }^{226}$

Upon closer examination, it appears that the Court's denial of standing is influenced by factors beyond just the element of speculation it finds in the alleged injury. The chances of future injury brought about by an undisciplined police force were not unlikely. ${ }^{227}$ The trial court identified over forty incidents of alleged police department misconduct, along with alleged inadequacies in the complaint procedures. ${ }^{228}$ This "pattern of abuse,"

222423 U.S. 362 (1976).

223 See id. at 368 .

224 See id. at 365 n.2.

${ }^{225}$ Id. at 372 (quoting O'Shea v. Littleton, 414 U.S. 488, 495-96 (1974)).

${ }^{226} \mathrm{Id}$. (citing O'Shea, 414 U.S. at 496-97 (holding that where allegations do not name specific violations by individual named parties, plaintiffs lack standing to obtain injunctive relief, which would require the Court to anticipate the circumstances attending the future wrong, taking the Court impermissibly "into the area of speculation and conjecture $\left.{ }^{n}\right)$ ).

${ }^{227}$ See Chayes, supra note 6 , at 20 (noting that patterns of police abuse could justify a grant of standing, as in Allee v. Medrano, 416 U.S. 802 (1974), which involved misconduct by the Texas Rangers).

${ }_{228}$ See Council of Orgs. on Phila. Police Accountability \& Responsibility (COPPAR) v. Rizzo, 357 F. Supp. 1289, 1294-316 (E.D. Pa. 1973) (detailing numerous instances of police abuse and misconduct which, coupled with inadequate complaint procedure, gave rise to the injunction at issue in the Rizzo litigation), aff'd sub nom. Goode v. 
suggesting that future injury is likely to occur, in and of itself should have overcome the constitutional limitation on speculation. ${ }^{230}$ The trial court, however, also found an actual "policy of the department to discourage the filing of citizen complaints, [and] to avoid or minimize the consequences of proven police misconduct." ${ }^{231}$ With a pattern of abuse and a policy of denying redress, it is difficult to see why the plaintiffs' future injury is prohibitively speculative. The district court could in its discretion conclude that the lack of discipline directly brought about the pattern of abuse.

Once again, the Supreme Court did not limit its constitutional analysis to the appropriate requirements, but rather deferred to principles of federalism. Indeed, the Court explicitly stated that "appropriate consideration must be given to principles of federalism in determining the availability and scope of equitable relief." 232 The Court imported what should be the prudential concern of federalism into its constitutional analysis, ${ }^{233}$ improperly increasing the level of directness required to overcome the Article III prohibition on speculative injuries.

A similar incorporation of what should be prudential concerns occurred in Los Angeles v. Lyons. ${ }^{234}$ As noted earlier, the Court held that Lyons lacked standing to bring an injunctive cause of action against future chokeholds because his alleged future injury was impermissibly speculative. ${ }^{235}$ It is not so clear, however, that his injury was that speculative. ${ }^{236}$ Indeed, "Lyons is a striking

Rizzo, 506 F. 2d 542 (3d Cir. 1974), rev'd, 423 U.S. 362 (1976).

${ }^{229}$ Chayes, supra note 6 , at 20.

${ }^{230}$ See Rizzo, 423 U.S. at 383-84 (Blackmun, J., dissenting) (arguing that whether violations are remotely or directly traceable to police department policy is a question of degree on which the Court should not supplant the conclusion of the district court's detailed findings that the violations were a pattern likely to recur in the face of official indifference).

${ }^{231}$ COPPAR, 357 F. Supp. at 1318.

${ }^{232}$ Rizzo, 423 U.S. at 379 (emphasis added) (citation omitted); see also Nichol, supra note 6 , at 99 ("The Court's negative ruling on injury . . . reflected its broader belief that the plaintiffs sought an 'unwarranted intrusion by the federal judiciary into the discretionary authority' committed to local and state officials." (quoting Rizzo, 423 U.S. at 366)).

${ }^{233}$ See TRIBE supra note 42, § 3-30, at 208 ("The Court's reference to [principles of federalism] was not appropriate ....").

244 461 U.S. 95 (1983).

${ }^{235}$ See supra notes 115-20 and accompanying text (outlining constitutional standing requirement that threatened future injury be real and immediate, not speculative).

${ }^{236}$ The dissent cited several statistics which demonstrated a good possibility that the police could again apply a chokehold to Lyons. For example, between 1975 and 1983, 12 African-American men died following the use of police chokeholds. See 
example of how the Court distorts the injury requirement in order to serve the ends" of federalism. ${ }^{237}$ As in Rizzo, the Court imported federalism into its constitutional analysis. It stated: "recognition of the need for a proper balance between state and federal authority counsels restraint in the issuance of injunctions against state officers engaged in the administration of the States' criminal laws." 238 Such concerns about federalism should be prudential and distinct from the constitutional analysis.

\section{Historical Manipulation of Redressability}

The Court often uses redressability to import prudential concerns. In Duke Power Co. v. Carolina Environmental Study Group, Inc. ${ }^{239}$ for example, an environmental organization sued the Nuclear Regulatory Commission and a utility company that was constructing nuclear power plants near members' homes. The plaintiffs claimed that the Price-Anderson Act, ${ }^{240}$ which limited liability in the case of a nuclear accident, constituted an unconstitutional taking by denying full compensation for property in the event of a nuclear accident. ${ }^{241}$ They sought a declaratory judgment pronouncing the Act unconstitutional. ${ }^{242}$

The Court granted standing because the plaintiffs satisfied the injury requirement via "the environmental and aesthetic consequences of the thermal pollution of the two lakes in the vicinity of the disputed power plants." 243 Additionally, they satisfied redressability by demonstrating that absent the legislation, there was a "substantial likelihood" that the nuclear plants would not be

Lyons, 461 U.S. at 115-16 (Marshall, J., dissenting) (footnotes omitted). Lyons was a 24-year-old African-American male. See id. at 114. Also, it had "been the official policy of the city to permit police officers to employ chokeholds in a variety of situations where they face no threat of violence." Id. at 116. Indeed the nonspeculative nature of Lyons's injury has become much clearer in light of the Rodney King episode. See Valerie Richardson, City, Black Leaders Faulted for Actions, WAsh. TIMES, May 1, 1992, at B4 (quoting Jesse Jackson as blaming the L.A. riots in the aftermath of the Rodney King verdict on the "Los Angeles Police Department's "history of abuse'").

${ }^{237}$ Nichol, supra note 6 , at 100 .

${ }^{258}$ Lyons, 461 U.S. at 112. American Postal Workers Union v. Frank, 968 F.2d 1373, 1377 n.5 (1st Cir. 1992), explains that Lyons invoked "principles of ... federalism in support of its decision[] against federal jurisdiction."

${ }^{239} 438$ U.S. 59 (1978).

24042 U.S.C. § 2210 (1988).

241 See Duke Power, 438 U.S. at 69.

${ }_{212}$ See id. at 67 (footnote omitted).

243 Id. at 73. 
completed. ${ }^{244}$ This conclusion rested on testimony by nuclear industry experts that they would not participate in developing nuclear power plants without the Act's assurance of diminished liability. ${ }^{245}$ While such a showing may satisfy the constitutional level, it is important to bear in mind that there are real doubts as to whether the invalidation of the Act would actually redress the injury. For instance, corporate officials admitted at the time of the trial that they "would have built the plants regardless of the Act." 246 Additionally, trial court evidence revealed that the Company had already invested most of its $\$ 1$ billion budget in the plant by the time of the trial. ${ }^{247}$ It seems likely that the power companies would not have wanted to lose that money and would have completed the plant, even with the increased possibility of liability absent the Act. Nonetheless, the Court granted standing, holding that plaintiffs satisfied the required redressability level. Is the Duke Power decision reconcilable with other cases?

In Simon v. Eastern Kentucky Welfare Rights Organization ("EKWRO"), ${ }^{248}$ the Court denied standing in part due to insufficient redressability. The plaintiffs sued the Treasury Department, challenging a new IRS regulation ${ }^{249}$ which eliminated a requirement that a hospital must operate "to the extent of its financial ability for those not able to pay" in order to receive favorable tax treatment. ${ }^{250}$ The plaintiffs, persons unable to afford hospital services, alleged that the new IRS regulation would encourage hospitals to deny service to indigents in violation of the tax code. ${ }^{251}$ The Court acknowledged that the plaintiffs had suffered an injury, as they would now be denied hospital services, ${ }^{252}$ but it denied standing on redressability grounds, reasoning that the plaintiffs could not show that the hospitals would not "forgo

244 Id. at 75; see also Carolina Envtl. Study Group, Inc., v. United States Atomic Energy Comm'n, 431 F. Supp. 203, 215-18 (W.D.N.C. 1977) (noting that nuclear industry officials and executives testified in support of renewing the Act that they would not be able to complete their nuclear power plants without extension of the Act's limited liability), rev'd sub nom Duke Power Co. v. Carolina EnvtI. Study Group, Inc., 438 U.S. 59 (1978).

${ }^{245}$ See Duke Power, 438 U.S. at 75.

${ }^{246}$ Chayes, supra note 6 , at 21 n.105 (citation omitted).

${ }^{247}$ See Carolina Envtl. Study Group, 431 F. Supp. at 206.

${ }_{248}^{426}$ U.S. 26 (1976).

${ }^{249}$ See Rev. Rul. 69-545, 1969-2 C.B. 117.

${ }^{250}$ EKWRO, 426 U.S. at 31 (quoting Rev. Rul. 56-185, 1956-1 C.B. 202).

${ }^{251}$ See $i d$. at 33 .

${ }^{252}$ See id. at $40-41$. 
favorable tax treatment to avoid the undetermined financial drain of an increase in the level of uncompensated services. "253 It was thus "only speculative" whether the requested remedy would redress the injury. ${ }^{254}$

In all likelihood, however, a denial of favorable tax treatment would have redressed the injury. When the IRS gives a hospital favorable tax treatment, it classifies the hospital as a charitable organization in accordance with $\S 501(c)(3)$ of the tax code. ${ }^{255}$ Such a classification means that potential donors, when donating money to the hospital, can deduct the donations. ${ }^{256}$ In effect, when the IRS gives a hospital favorable tax treatment, it actually makes the hospital a much more favorable place for donors to give money than if the IRS did not confer favorable tax treatment. ${ }^{257}$ The plaintiffs argued that the "hospitals that denied [the plaintiffs] service receive substantial donations deductible by the donors," making it very possible that "these hospitals . . . are so financially dependent upon the favorable tax treatment afforded charitable organizations that they would admit" the plaintiffs for free treatment. ${ }^{258}$ Yet the Court denied standing. ${ }^{259}$

The decisions in EKWRO and Duke Power are difficult to reconcile. The chances of redressability in EKWRO appear greater than in Duke Power, yet the Court only granted standing in Duke Power. As one commentator explained:

Personally, I have no trouble with the Court's conclusion that the plaintiff had standing in Duke Power. My difficulty is in understanding why a subsidy to the nuclear industry can properly be said to have caused the construction of nuclear power plants,

253 Id. at 43 .

${ }^{254}$ Id. at 44 (citing Linda R. S. v. Richard D., 410 U.S. 614,618 (1973)).

255 See id. at 29 (citing 26 U.S.C. \$ 501(c)(3) (1988)).

${ }^{256}$ See 26 U.S.C. $\$ 170$ (1988 \& Supp. IV 1992) (allowing for tax deductions for those who donate to charitable organizations).

${ }^{257}$ The ability to deduct a donation creates an economic incentive to make such a donation.

${ }^{258}$ EKWRO, 426 U.S. at 43; see also DAVIS, supra note 6, § 24:28, at 319 ("Voluntary nonprofit hospitals are ... dependent upon charitable contributions." (citation omitted)).

${ }^{259}$ Professor Chayes disagreed with the Court's decision on the ground that the congressional purpose for allowing deductions and other tax incentives is to shape favorable conduct. Therefore, a disallowance of deductions would redress the plaintiffs' injury by ultimately shaping the hospital's conduct. "Congress must believe that these [deductions] have some efficacy in inducing desired conduct on the part of taxpayers. Why should the Court treat that assumption as "purely speculative'?" Chayes, supra note 6, at 19 (quoting $E K W R O, 426$ U.S. at $42-43$ ). 
but a subsidy to the hospital industry does not have the same power to induce the provision of free medical services. ${ }^{260}$

Allen $v$. Wright ${ }^{261}$ and Norwood v. Harrison ${ }^{262}$ are even harder to reconcile. The plaintiffs in Allen were denied standing because the Court found no guarantee that the illegal IRS practices caused the lack of desegregation in the plaintiffs' schools. ${ }^{263}$ By contrast, the plaintiffs in Norwood challenged the validity of a Mississippi statutory program whereby the state purchased textbooks and gave them to both public and private schools. ${ }^{264}$ The state gave these books to both nondiscriminatory and discriminatory private schools. ${ }^{265}$ The plaintiffs-much like the Allen plaintiffs-alleged that the government's action, by providing such "direct state aid" to racially discriminatory private schools, would deter the process of desegregation. ${ }^{266}$ Unlike in Allen, however, the Court held that the plaintiffs showed adequate causation between the defendant's actions and the resultant lack of desegregation. ${ }^{267}$ The free books did indeed have "a significant tendency to facilitate, reinforce, and support private discrimination. ${ }^{268}$

An inconsistency appears to exist in the Court's finding that the tax-exempt status in Allen does not encourage desegregation while the granting of free books in Norwood does. ${ }^{269}$ "It hardly seems possible that the 'concrete injury' suffered by plaintiffs in Norwood differed significantly from the injury suffered by plaintiffs in [Allen]. ${ }^{270}$ The Court again looks at concerns that go beyond the appropriate constitutional question of redressability. The Allen decision is quite explicit about which of these concerns it includes in its analysis. The decision openly states that it is considering separation of powers concerns as part of its Article III limits. ${ }^{271}$

${ }^{260} \mathrm{Id}$. at 22.

261468 U.S. 737 (1984).

262413 U.S. 455 (1973).

${ }^{263}$ See Allen, 468 U.S. at 753 ("[T]he alleged injury is not fairly traceable to the assertedly unlawful conduct of the IRS."); see also supra notes 136-41 and accompanying text (discussing the denial of standing in Allen).

${ }^{264}$ See Norwood, 413 U.S. at 458.

265 See id.

266 See id. at 457.

${ }^{267}$ See id. at 455 .

${ }^{268} \mathrm{Id}$. at 466.

${ }^{269}$ On the contrary, one might argue that denial of tax-exempt status has greater financial consequences than denial of mere textbooks and, thus, a threat to deny taxexempt status would be more effective in encouraging desegregation.

${ }^{270}$ Roseborough, supra note 41 , at 1030.

${ }^{271}$ See Allen, 468 U.S. at 752 (stressing that "the standing inquiry must be 
The problem is that the Article III requirements are not well-suited to furthering separation of powers principles. ${ }^{272}$

The plaintiffs in Allen seem to satisfy traditional notions of redressability. The Court in Allen nonetheless suggested that the plaintiffs' injury was not redressable because the causal link between withdrawal of tax exemptions and the integration of public schools was speculative. 273 There are three reasons why the Court's analysis is probably incorrect. ${ }^{274}$ First, the absence of the exemption would have likely resulted in fewer contributions to private schools. ${ }^{275}$ Second, "educational institutions are quite vulnerable to loss of income resulting from the increased cost of donations." ${ }^{276}$ Third, many white students would be forced to enroll in the public schools because fewer would be able "to afford the cost of discriminatory schools as the loss of contributions . . made attendance more expensive."277 Hence it seems pretty clear that the plaintiffs should satisfy the redressability prong. ${ }^{278}$ The Court still denied standing on the grounds of insufficient redressability, however, based upon its "introduc[tion] [of] separation of powers into its [redressability] analysis." ${ }^{279}$ As a result, the Court in Allen "applied . . . its standing test far more strenuously than article III demands and consequently left meritorious plaintiffs without relief." 280

answered by reference to the Art. III notion that federal courts may exercise power only ... . when adjudication is "consistent with a system of separated powers" (quoting Chicago \& Grand Truck Ry. Co. v. Wellman, 143 U.S. 339, 345 (1892)); Haitian Refugee Ctr. v. Gracey, 809 F.2d 794, 804 (D.C. Cir. 1987) (interpreting Allen as "the Supreme Court's more recent statement that the entire concept of article III rests on separation of powers"); 13 WRIGHT ET AL., supra note 12, \$ 3531.2 (Supp. 1993) (noting the Allen Court's explicit linkage between Article III and separation of powers).

${ }^{272}$ See supra notes $47-65$ and accompanying text.

${ }^{273}$ See Allen, 468 U.S. at 756-61 (defining the causal link as "not fairly traceable" and "attenuated at best").

${ }^{274}$ See Roseborough, supra note 41, at 1029 (discussing the reasons).

275 See id. (citing Martin Feldstein, The Income Tax and Charitable Contributions: Part II-The Impact on Religious, Educational and Other Organizations, 28 NAT'L TAX J. 209, 224 (1975) (conducting study which concludes that the quantity of a gift to a school is closely related to the cost of a gift)).

${ }^{276}$ Roseborough, supra note 41 , at 1029.

277 Id.

${ }^{278}$ See Allen, 468 U.S. at 789 (Stevens, J., dissenting) ("Considerations of tax policy, economics, and pure logic all confirm the conclusion that [plaintiffs'] injury in fact is fairly traceable to the Government's allegedly wrongful conduct."). Professor Tribe characterizes Stevens's dissent as a "powerful argument." TRIBE, supra note 42, § 318, at $131 \mathrm{n} .10$.

${ }_{279}$ Allen, 468 U.S. at 789 (Stevens, J., dissenting).

${ }^{280}$ Roseborough, supra note 41, at 1026; see also Nichol, subra note 33 . at 658 
Courts are not always clear as to what concern they will import into the Article III tests. For example, the particular concern that the Court imported in $E K W R O$ is not as immediately visible as it was in Rizzo or in Lyons. ${ }^{281}$ The relevant point, however, is that the Court consistently analyzes factors as part of the Article III analysis that are ill-fitted to the three-pronged Article III test. ${ }^{282}$ Such factors are clearly included to a certain extent in Alabama Power, Schlesinger, Rizzo, Lyons, EKWRO, and Allen. In Lujan, the Court imports prudential concerns to an unprecedented extreme. ${ }^{283}$

("Allen, in short, moves standing doctrine in the wrong direction.").

${ }^{281}$ In $E K W R O$, the Court may have been showing deference to the IRS. The Court in EKWRO (and perhaps Allen too) may have been apprehensive about sanctioning private citizens' suits which challenged IRS tax allocations. See MICHAEL A. GRAETZ, FEDERAL INCOME TAXATION 91 (2d ed. 1988) (questioning the "appropriate[ness] [of] allow[ing] private enforcement of the tax law-whereby citizens, who believe the IRS is not collecting enough taxes, sue to insure the collection").

Moreover, even in such cases as Lyons and Rizzo where the Court makes it quite clear that it is worried about the concern of federalism, one commentator has suggested that the Court is concerned with an additional outside factor: "[o]ne senses in a variety of cases that the Court carries little empathy for a litigant who bases future harm on the possibility of repeated encounters with the criminal justice system." Nichol, supra note 6, at 90 . It is at least plausible that the plaintiffs in Lyons and Rizzo were denied standing not because of the speculative nature of their injuries, as the Court held, but rather because they based their injuries upon harm which depended upon a "run-in" with the law. See id.

${ }^{282}$ See supra notes 65-67 and accompanying text (noting the poor fit between the Article III test and certain potential justifications for standing). Admittedly, the ability to accurately identify the particular inappropriate concern which the Court imports into its three-pronged constitutional analysis provides greater evidence that the Court actually does erroneously weigh inappropriate factors. The Court is not always explicit, however, about its particular concerns.

Often, the Court just uses the standing doctrine to attain the result it would have reached on the merits. Dean Nichol argues that in many Supreme Court standing decisions-such as Alabama Power, EKWRO, Schlesinger, and Allen-the Supreme Court pretends to perform a proper standing analysis but the decision is really based on "the Court's view of the claim on the merits." Nichol, supra note 33, at 649; see also TRIBE, supra note $42, \S 3-18$, at 131 n.10 (noting that sometimes the Court will ignore proper standing inquiry "in its . . . zeal to reach the merits"); Fletcher, supra note 6, at $236(" \mathrm{~A}]$ standing determination is . . . merely a surrogate for a determination on the merits ....").

${ }^{283}$ See Nichol, supra note 38, at 1142 (noting that Lujan "will mark a transformation in the law of standing"). 


\section{B. Lujan's Manipulation of the Constitutional Analysis}

One Supreme Court doctrine suggests that a Court has a judicial duty to avoid rendering decisions about constitutional issues affecting legislation unless an immediate decision is necessary. ${ }^{284}$ The Court derives this doctrine from notions about the need for limitations on "judicial review of governmental action for constitutionality." 285 It seems to follow that if the Court need only discuss one prong of a multiprong test in order to decide a case, then, out of judicial restraint, the Court should abstain from deciding the remaining prongs which are unnecessary to the outcome of the case. Nonetheless, in Lujan, the Court ignored this doctrine of judicial restraint. ${ }^{286}$ In the first part of its opinion, the Court held that the plaintiff lacked sufficient injury to receive standing. ${ }^{287}$ This should have been enough to dispose of the case. Yet the Court still proceeded to discuss redressability even though it had already decided that the plaintiff lacked the necessary injury. ${ }^{288}$ The Court's failure to exercise judicial restraint resulted in the importation of what should be prudential factors into two prongs, thereby distorting the constitutional analysis.

As previously discussed, the plaintiff in Lujan sued in order to get a judicial determination of the proper geographic scope of section $7(a)(2)$ of the Endangered Species Act ("ESA"). ${ }^{289}$ The

${ }^{284}$ See Rescue Army v. Municipal Court, 331 U.S. 549, 568-69 (1947) (“'[T]he Court [has] developed . . . a series of rules under which it has avoided passing upon a large part of all the constitutional questions pressed upon it for decision." (quoting Ashwander v. Tennessee Valley Auth., 297 U.S. 288, 346 (1936) (Brandeis, J., concurring))).

285 Id. at 571.

${ }^{286}$ See Pierce, supra note 48, at 1200 ("The majority opinion in [Lujan] is simply inconsistent with the principle of judicial restraint."). It is ironic that Justice Scalia, one of the Court's leading proponents of judicial restraint, should write the opinion which ignores this constitutional doctrine advocating restraint. See Michael A. Perino, Justice Scalia: Standing, Environmental Law, and the Supreme Court, 15 B.C. ENVTL. AFF. L. REv. 135, 157 (1987) (describing Scalia's "main policy" as "judicial self-restraint"); see also Scalia, supra note 8 , at 881 (citing the need to decrease "overjudicialization").

${ }^{287}$ See Lujan, 112 S. Ct. at $2137-40$ (outlining the Court's reasoning in denying the injury argument).

${ }_{283}$ Justice Kennedy's concurring opinion adheres to the doctrine of restraint. See id. at 2146 (Kennedy, J., concurring) ("In light of the conclusion that [plaintiffs] have not demonstrated a concrete injury ... sufficient to support standing . . . , I would not reach the issue of redressability ....").

${ }^{289}$ See supra notes 13-21 and accompanying text (describing the plaintiffs' challenge in the Lujan case); see also 16 U.S.C. \$ 1536(a)(2) (1988) (codifying § 7(a)(2) of the ESA). 
plaintiff, an environmental group named Defenders of Wildlife, alleged that several of its members would suffer particularized injuries beyond that which the public at large would suffer if the ESA's proper geographic scope were not properly enlarged. ${ }^{290}$ The Court held that these injuries did not reach a constitutional level. ${ }^{291}$ The Court reasoned further that the members' injuries were not redressable by the requested remedy. ${ }^{292}$ Even if the Court granted the requested relief and forced the Secretary to consult on foreign projects, there was no guarantee that the plaintiffs' injuries would be cured. For both of these reasons, the Court denied standing. While the Court supposedly denied standing for reasons related to the three-pronged Article III test, it really weighed concerns that should be independent of the constitutional analysis.

\section{Injury}

\section{a. Inconsistent Particularity}

The Supreme Court has traditionally distinguished between a generalized grievance, which always satisfies Article III but usually does not pass the prudential limits, and a grievance common to all members of the public, which never satisfies the particularity requirement of Article III. ${ }^{293}$ The Court often does not hear cases of generalized grievances, though they pass constitutional muster, because those cases raise separation of powers problems. ${ }^{294}$ The

${ }^{290}$ Apart from the injuries to Amy Skilbred, see supra notes 1-5 and accompanying text, the plaintiff also alleged particularized injuries to several other members. See Respondents' Brief at 19-22, 24-26, Lujan (No. 90-1424). For example, Dr. H. Elliott McClure, a member of Defenders, has worked as an ecologist in Southeast Asia for 25 years and plans to return to Southeast Asia to study the hornbill, a species of bird which he has studied in the past. Several projects which the U.S. government helps to support are currently threatening the future existence of the hornbill. See id. at 19-21.

${ }^{291}$ See Lujan, $112 \mathrm{~S}$. Ct. at $2137-40$ (explaining the injury analysis).

292 See id. at $2140-42$.

293 For a discussion of the difference between a "generalized grievance" and a "grievance common to all members of the public," see supra note 114 .

294 See Valley Forge Christian College v. Americans United for Separation of Church \& State, Inc., 454 U.S. 464, 475 (1982) ("[T]he Court has refrained from adjudicating . .. 'generalized grievances,' . . . most appropriately addressed in the representative branches.") (citation omitted); Duke Power Co. v. Carolina Envtl. Study Group, Inc., 438 U.S. 59, 80 (1978) (explaining that decisions to decline to grant standing in cases of generalized grievances "derive from general prudential concerns 'about the proper-and properly limited-role of the courts in a democratic society'" 
Court in Lujan, however, specifically takes this prudential concerngeneralized grievances-and imports it into its constitutional analysis by interpreting Article III as prohibiting generalized grievances. ${ }^{295}$ The Court, quoting from United States v. Richardson, ${ }^{296}$ explained that a suit which "rested upon an impermissible 'generalized grievance' ... was inconsistent with the 'framework of Article III." ${ }^{297}$ The problem with the Court's use of language from Richardson is that it completely distorts the language of Richardson.

It is not clear whether the denial of standing in Richardson is based upon prudential or constitutional grounds. Many sources argue that the denial was based entirely upon prudential grounds. ${ }^{298}$ If such an interpretation of Richardson is accurate, the Lujan Court's use of Richardson as evidence that generalized grievances are inconsistent with Article III is an outright distortion of precedent. It is arguable, however, that Richardson denied standing on a constitutional basis. ${ }^{299}$ Even if the denial is constitutionally motivated, however, Richardson never places generalized grievances within the framework of an Article III denial of standing. ${ }^{300}$ The reference to "generalized grievances" 301 is stated in a different context than the reference to "Article III." Court in Lujan, by taking unrelated quotations from Richardson and magically connecting them, imports the traditionally prudential worry of generalized grievances into Article III limitations.

(quoting Warth v. Seldin, 422 U.S. 490, 498 (1975))).

${ }^{295}$ See Lujan, 112 S. Ct. at 2144.

296418 U.S. 166 (1974).

${ }^{297}$ Lujan, 112 S. Ct. at 2144 (quoting Richardson, 418 U.S. at 171, 176).

298 See Duke Power, 438 U.S. at 80 (citing Richardson in support of the fact that a "generalized grievance" raises "prudential concerns"); Warth v. Seldin, 422 U.S. 490, 499 (1975) (citing Richardson for the proposition that a "generalized grievance" is "[a]part from the minimum constitutional mandate"); see also Logan, supra note 22, at $50 \mathrm{n.58}$ (describing the holding in Richardson as "a denial of standing because plaintiffs' generalized grievances violated prudential rules").

${ }^{299}$ Arguably, the plaintiff's challenge-that the with holding of detailed information on CIA expenditures unconstitutionally prevents the plaintiff from properly fulfilling "his obligations as a member of the electorate in voting for candidates seeking national office," Richardson, 418 U.S. at 176-is common to all members of the public and, hence, constitutionally precluded by Article III.

${ }^{300}$ Nowhere in Richardson does the Court state that federal courts should not hear generalized grievances because Article III prohibits it.

${ }^{301} I d$. at 176.

${ }^{302}$ Id. at 171 . 


\section{b. Inconsistent Imminence}

The Court in Lujan held that the plaintiffs were not returning soon enough to the foreign countries to satisfy the imminence requirement. ${ }^{303}$ This denial of standing becomes especially troublesome when one considers Lucas v. South Carolina Coastal Council. ${ }^{304}$ In Lucas, the plaintiff purchased two beachfront lots in South Carolina in $1986 .{ }^{305}$ In 1988 , the state enacted a coastal regulation which barred Lucas from erecting any permanent structures on his lots. ${ }^{306}$ He filed suit against the state, alleging that the state violated his Fifth and Fourteenth Amendment rights. ${ }^{307}$ The Court held that he should be granted judicial access. ${ }^{308}$ It is difficult to reconcile the Court's finding in Lucas here that the imminence requirement was satisfied with the denial of such a finding in Lujan. Although Lucas brought his suit in 1988, the "trial court made no findings of fact that Lucas had any plans to use the property from 1988 to $1990 .{ }^{\text {"309 }}$ Indeed Lucas himself testified "that he was 'in no hurry' to build 'because the lot was appreciating in value." ${ }^{\text {"310 }}$ Lucas brought suit in 1988 but the governmental regulations which barred Lucas from erecting structures on his lots did not affect Lucas until 1990-the year that he first planned to build upon his lots. The point is that Lucas had standing to sue in 1988 even though he would not be injured until $1990 .^{311}$ The Court held that his injury was sufficiently imminent. In contrast, the plaintiffs in Lujan, whose injury the dissent characterized as occurring "soon," did not satisfy the imminence requirement. ${ }^{312}$

Once again, the Court is importing what should be nonconstitutional considerations into its constitutional analysis. It is plausible that the Court did not find the Defenders of Wildlife members' injuries to be imminent and did find Mr. Lucas's injury to be

${ }^{303}$ In contrast, the dissent explained that the plaintiffs would "soon return to the project sites. ..." Lujan, 112 S. Ct. at 2152 (Blackmun, J., dissenting).

sos 112 S. Ct. 2886 (1992).

${ }^{305}$ See id. at 2887.

${ }^{306}$ See id.

${ }^{307}$ See id.

${ }^{308}$ See id. at 2891.

${ }^{309}$ Id. at 2908 n.5 (Blackmun, J., dissenting).

${ }^{310} I d$.

s11 As the dissent explains, it is "baffling," given Lujan, that the plaintiff in Lucas "has demonstrated injury in fact." Id.

${ }^{312}$ Lujan, 112 S. Ct. at 2152 (Blackmun, J., dissenting). 
imminent based on the prudential concern of internationalism rather than the appropriate question of imminence. Lucas's challenge affected activity in South Carolina, ${ }^{313}$ while Skilbred's challenge affected activity in Sri Lanka. ${ }^{314}$ Ms. Skilbred's challenge to the overseas activity raised a concern that a judicial resolution could offend a foreign nation. No such concern was at stake in Lucas. ${ }^{315}$ While the Court in Lujan never explicitly pointed to an international concern in its decision, it did implicitly import such concerns, raising the constitutional limits. ${ }^{316}$ It explained that a plaintiff "who observes or works with animals of a particular species in the very area of the world where that species is threatened by a federal decision" may have standing to challenge the threatening activity, but a plaintiff who works with a species that resides in a different area of the world does not have standing. ${ }^{317}$ The Court seems acutely aware that "requiring federal agencies acting abroad to comply with the consultation requirements of section 7 would interfere with the sovereignty of foreign nations. ${ }^{\text {318 }}$ Furthermore, the dissent, recognizing the implicit international concerns present in the Court's opinion, referred to the Court's reasoning as "geographic formalism."319

This Comment does not propose that the Court ignore international concerns when analyzing a question of standing. Often, the

${ }^{313}$ See Lucas, 112 S. Ct. at 2887.

${ }^{314}$ See Lujan, 112 S. Ct. at 2138.

315 The Court in Lucas did attempt to distinguish Lujan on other grounds by claiming that each case arrived at a different procedural stage. "Lujan, since it involved the establishment of injury-in-fact at the summary judgment stage, required specific facts to be adduced by sworn testimony . . ." Lucas, 112 S. Ct. at 2892 n.3. Conversely, Lucas arrived at the Court on the pleadings and only required "allegations of fact." Gwaltney of Smithfield Ltd. v. Chesapeake Bay Found., 484 U.S. 49, 65 (1987) (quoting Warth v. Seldin, 422 U.S. 490, 501 (1975)).

There are two problems with the Court's reasoning. First, Lucas did not arrive on the pleadings. "Lucas had a full trial on his claim ... ." Lucas, 112 S. Ct. at 2908 n.5 (Blackmun, J., dissenting). Second, even if Lucas did arrive on the pleadings, the Court often requires a burden of persuasion that will satisfy summary judgment while the case is still at the pleadings stage. For example, although EKWRO, 426 U.S. at 4446, arrived at the Supreme Court on the pleadings, "the Court inverted normal pleading presumptions by refusing to allow normal inferences to be drawn from general allegations." Nichol, supra note 6, at 72 n.25.

${ }^{316}$ See Nichol, supra note 38, at 1165 (noting that "Justice Scalia raised the barriers of the case or controversy requirement merely to limit the geographical confines of the Endangered Species Act").

${ }^{317}$ Lujan, 112 S. Ct. at 2139-40.

${ }^{318}$ Henry J. Blum, The Extraterritorial Application of Section 7 of the Endangered Species Act, 13 Colum. J. ENVTL. L. 129, 132 (1987).

${ }^{319}$ Lujan, 112 S. Ct. at 2154 (Blackmun, J., dissenting). 
Court has rightfully denied judicial access because such a grant would arouse international tensions. ${ }^{320}$ Instead, the Court should include concern for international relations in its prudential analysis, ${ }^{321}$ not in its constitutional analysis of whether there exists an imminent injury. The consequence of such an inclusion into the constitutional analysis is that the courts and Congress, neither of which can overcome a constitutional barrier to standing, will not be able to grant standing to plaintiffs who satisfy previous constitutional obstacles and who do not implicate international concerns.

Even if the Court in Lujan were correct in holding that the plaintiffs' unspecified date of return failed to satisfy the imminence requirement, there is an additional problem with the Court's analysis. Generally, when a court decides a question of imminence in environmental cases, it should focus on the imminence of the harm to the environment rather than the imminence of the harm to the particular plaintiff. ${ }^{322}$ Yet the Court in Lujan measured the imminence with respect to the litigant and not with respect to the environment. The plaintiffs alleged an injury to their vocational and aesthetic interests in observing certain endangered species. ${ }^{323}$ Instead of focusing on how soon the species would become extinct, the Court focused on when the plaintiffs "inten[ded] to return" to the places where they had previously studied these species. ${ }^{324}$ The Court required "concrete plans" which would demonstrate the plaintiffs' intentions to return at some specified date. ${ }^{325}$

${ }^{320}$ See Banco Nacional de Cuba v. Sabbatino, 376 U.S. 398, 423 (1964) (expressing the idea that judicial interference with foreign acts "may hinder rather than further this country's pursuit of goals both for itself and for the community of nations"); see also GARY B. BORN \& DAVID WESTIN, INTERNATIONAL CIVIL LITIGATION IN UNITED STATES COURTS 68 (1989) ("Assertions of personal jurisdiction over foreigners may also arouse foreign resentment or interfere with U.S. foreign relations.").

${ }^{321}$ See infra note 392 and accompanying text (discussing the propriety of including international concerns as part of the prudential analysis).

${ }^{322}$ Justice Stevens agrees that "the 'imminence' of . . . an [environmental] injury should be measured by the timing and likelihood of the threatened environ nental harm, rather than . . . by the time that might elapse between the present and the time when the individuals would visit the area if no such injury should occur." Lujan, 112 S. Ct. at 2148 (Stevens, J., concurring) (citation omitted); see also Sierra Club v. Yeutter, 911 F.2d 1405, 1418 (10th Cir. 1990) (holding that the relevant inquiry is whether there is an "imminent threat to [the] wilderness"); Respondents' Brief at 24, Lujan (No. 90-1424) (arguing that the imminence of the "date of [the plaintiff's] return is irrelevant" because "if the endangered species are eradicated . . ., they will be gone for the rest of timen $)$.

${ }^{323}$ See Lujan, 112 S. Ct. at 2137.

${ }^{324}$ Id. at 2138.

${ }^{325} \mathrm{Id}$. 
The Court's imminence analysis is illogical. It is self-evident that the plaintiffs' injury "will occur as soon as the animals are destroyed." ${ }^{226}$ The case of Gilmore $v$. Utah ${ }^{327}$ lucidly illustrates this point. In Gilmore, Gary Gilmore's mother challenged the state's decision to execute her son. ${ }^{328}$ Mrs. Gilmore satisfied the constitutional standing requirements. ${ }^{329}$ Yet one of the absurd conclusions that can be drawn from Lujan is that Mrs. Gilmore may no longer satisfy the imminence requirement. Presumably, the Court would measure imminence not by the timing of the execution (analogous to the death of an endangered species) but rather by the timing of Mrs. Gilmore's intent to visit her son (analogous to the time when the Lujan plaintiffs next intended to see the endangered species). If Mrs. Gilmore possessed merely the intention to visit her son without any evidence of concrete plans, then she would be denied standing to challenge the impending death of her son due to the lack of an imminent injury. ${ }^{330}$ Surely this cannot be the correct result. The Court's requirement of concrete travel plans to prove imminence goes against logic.

The Court might respond to this criticism by arguing that it required concrete plans to satisfy the constitutional requirement of a personal stake rather than to satisfy the constitutional requirement of imminence. After all, a plaintiff who has imminent plans to travel to Sri Lanka to observe endangered species most likely has a greater personal stake than the common public. Two problems exist with this argument. First, the Gourt makes it quite clear that its requirement of concrete travel plans relates directly to the

${ }^{326}$ Id. at 2148 (Stevens, J., concurring).

327429 U.S. 1012 (1976).

${ }^{328}$ See id. at 1013.

${ }^{329}$ The Court actually denied standing to Mrs. Gilmore, but, as Gene Nichol, Jr., argues, "[c]learly ... [ $t]$ he injuries she sustained as the result of her son's death would more than meet the dictates of article III." Nichol, supra note 6, at 97 . Instead, Mrs. Gilmore was denied standing due to "[p]rinciples of third party standing." Id.

${ }^{350}$ In Lujan, Justice Blackmun, in dissent, pokes fun at the plurality's formalistic imminence requirement. For example, he wonders if "a Federal Torts Claims Act plaintiff alleging loss of consortium should make sure to furnish this Court with a 'description of concrete plans' for her nightly schedule of attempted activities." Lujan, 112 S. Ct. at 2154 (Blackmun, J., dissenting). Similarly, one wonders if a mother such as Mrs. Gilmore must outline and furnish specific plans to visit her son,

It is doubtful that the Supreme Court would actually hold that either Mrs. Gilmore or the Federal Torts Claims Act plaintiff would fail to satisfy the imminence requirement. The point of both examples is to illustrate potential flaws in the Court's articulation of the standard. 
imminence test: '[S]uch 'some day' intentions-without any description of concrete plans ... do not support a finding of the 'actual or imminent' injury that our cases require." ${ }^{\text {"31 }}$ Second, even if the requirement of concrete plans were part of the Court's personal stake analysis, there is no reason to assume that a person could not allege a personal stake merely because she does not possess evidence of imminent plans to travel to a foreign country. Mitigating factors can arise that obviate her concrete plans. For example, in Lujan, Ms. Skilbred was not able to make travel plans to go to Sri Lanka because " $[\mathrm{t}]$ here [was] a civil war going on." Moreover, she did establish other factors-her past trip to Sri Lanka, her fixed intent to return and her vocational duties involving the threatened species ${ }^{333}$-which should have satisfied the personal stake requirement. ${ }^{344}$ "[A] person who has visited ... an endangered species, has a professional interest in preserving the species and its habitat, and intends to revisit [the species] in the future has standing to challenge agency action that threatens their destruction." 335 Indeed, it seems Ms. Skilbred has shown a personal stake.

Once again, the Court appears to be expanding its constitutional analysis beyond the three-pronged constitutional requirements. Because many people might have a personal stake in an endangered species, ${ }^{336}$ the Court could have denied standing for prudential reasons. ${ }^{337}$ Instead, it suggested that in hearing "generalized grievance" cases where several people have a stake, ${ }^{338}$ such as Lujan, courts "would be discarding a principle fundamental to the separate and distinct constitutional role of the Third Branch" by hearing the case and therefore must deny standing on Article III

${ }^{331} \mathrm{Id}$. at 2138 .

332 Id. (quoting the deposition of Amy Skilbred). Similarly, Mrs. Gilmore would probably not have evidence of plans to see her son.

${ }^{333}$ See supra notes 1-3, 5 and accompanying text (proving Ms. Skilbred's personal stake in the species's preservation).

${ }^{334}$ See Stephen L. Kass \& Michael B. Gerrard, 'Lujan,' 'Lucas' and 'Dague': A Scalian Trilogy, N.Y. L.J., July 31, 1992, at 3, 27 (explaining the possibility that "the ongoing professional concern of two members of the plaintiff ... was sufficient to confer standing").

${ }^{335}$ Lujan, 112 S. Ct. at 2147 (Stevens, J., concurring).

${ }^{336}$ See id. at 2139.

${ }^{337}$ See supra notes 111-14 and accompanying text (explaining that the fact that many people have a stake in something points toward a prudential denial of standing, not a constitutional denial).

${ }^{338}$ Lujan, 112 S. Ct. at 2144. 
grounds. ${ }^{339}$ Because such separation of powers concerns should be irrelevant when considering the Article III test, ${ }^{340}$ they should be a part of the prudential analysis and, thus, properly eliminated from the constitutional doctrine.

\section{Redressability}

After importing what should be prudential concerns into the injury requirement, the plurality in Lujan proceeded to do the same to the redressability requirement. The Court held that the plaintiffs' requested remedy-a declaratory judgment forcing the Secretary to revise his regulations to require consultation on foreign projects which threatened endangered species-would not redress the environmental injury. ${ }^{341}$ The Court explained that even if the Secretary were forced to promulgate a regulation requiring consultation, there was no guarantee that the agencies, which were not parties to the suit, would be required to honor such a regulation: "[The Secretary] could be ordered to revise his regulation to require consultation for foreign projects. But this would not remedy [plaintiffs'] alleged injury unless the funding agencies were bound [to consult] by the Secretary's regulation, which is very much an open question." 342 The Court even concluded that "any relief the District Court could have provided in this suit against the Secretary was not likely to produce" results that would redress the plaintiffs' injury. ${ }^{343}$

It is very difficult to reconcile this portion of the Lujan decision with Tennessee Valley Authority v. Hill. ${ }^{344}$ In Hill, the Tennessee Valley Authority, a wholly-owned public corporation of the United States, built a dam which would, upon completion, impound water covering 16,500 acres. $^{345}$ In the process of building the dam, it was discovered that completion of the dam would seriously jeopardize the future existence of the snail darter, an endangered species. ${ }^{346}$ The plaintiffs brought an action under the $\mathrm{ESA}^{347}$ in

${ }^{339} \mathrm{Id}$. at $2144-45$.

${ }^{340}$ See supra notes 47-65 and accompanying text (explaining how the importation of separation of powers issues can distort the three-pronged analysis). The Court's importation in this instance distorts the personal stake analysis.

${ }^{341}$ See Lujan, 112 S. Ct. at 2140-42.

342 Id. at 2140.

${ }^{343} \mathrm{Id}$. at 2142.

344437 U.S. 153 (1978).

345 See id. at 157.

${ }^{346}$ See id. at 161-62. The snail darter was deemed legally endangered prior to the 
order to enjoin the dam's completion. ${ }^{348}$ The Court stated that the legislative history of Section 7 of the ESA "reveals an explicit congressional decision to require agencies to afford first priority to the declared national policy of saving endangered species." 349 Accordingly, it interpreted Section 7 as mandating the agencies to fulfill the statute's procedural requirements. ${ }^{350}$

The Court in Hill and the Court in Lujan examined the same statute yet disagreed on its interpretation. The Hill Court read Section $7(a)(2)$ as requiring an agency to consult, ${ }^{351}$ while the Lujan Court saw the consultation issue as permitting the agencies to have an option. ${ }^{352}$ The problem with the Lujan interpretation is that it ignored the actual mandate of the defendant himself. The Secretary's regulation states that “[a]11 Federal actions including 'conservation programs' are subject to the consultation requirements of $7(\mathrm{a})(2) .{ }^{\text {"353 }}$ The discussion accompanying the promulgation of the consultation regulation further shows the Secretary's intent, stating that the Secretary "believes that uniform consultation ... procedures are necessary. ${ }^{n 34} \mathrm{He}$ cannot publicly state, at one

plaintiffs' suit but after the TVA began construction of the dam. See id. at 161.

${ }^{347}$ Pub. L. No. 93-205, 87 Stat. 884 (1973) (codified as amended at 16 U.S.C. $\S \S 1531-1544$ (1988 \& Supp. IV 1992)).

${ }^{348}$ See Hill, 437 U.S. at 164.

$\$ 49$ Id. at 185.

${ }^{950}$ See id. at $185 \mathrm{n} .31$. Actually, the Court in Hill takes the analysis even further. It never explicitly discusses the agencies' procedural duties under $\$ 7$. Instead, it reasons that once agencies have consulted with the Secretary, thereby fulfilling the procedural requirements of $\S 7$, the agencies have an affirmative, substantive duty "to give endangered species priority over the "primary missions' of federal agencies." Id. at 185 . Indeed, the reason that the Court never explicitly discussed whether or not an agency has a duty to consult the Secretary in the first place is that the defendants conceded that agencies must consult. The defendants focused on the degree to which agencies had to obey the consultation requirement-not whether there was ever a consultation requirement. The defendants, while arguing that an agency "would not be prohibited from [jeopardizing an endangered species] if they deemed it necessary to do so," still conceded that $\$ 7$ "would require consultation." Id. at 185 n.31. The issue in Hill concerned the agencies' responsibility once they had already consulted with the Secretary. There was never even an issue as to whether the agencies had to consult in the first place.

${ }^{351}$ See id; see also Blum, supra note 318, at 131 n.20 (noting several situations where an agency is required to consult).

${ }^{352}$ See Lujan, 112 S. Ct. at 2140-41.

${ }^{35 s} 51$ Fed. Reg. 19,926, 19,929 (1986).

${ }^{354} 51$ Fed. Reg. 19,926, 19,928 (1986). Additionally, appeals courts have made it plain that consultation is mandatory. Agencies may only make a decision after they have fulfilled their $\$ 7$ procedural duties. See, e.g., National Wildlife Fed'n v. Coleman, 529 F. 2d 359, 371 (5th Cir. 1976) (explaining that "[f]ederal agencies are required to consult and obtain the assistance of the Secretary before taking any 
point in time, that uniform consultation procedures are required of the agencies and then, "for the convenience of this appeal, ... disavow his prior public ... position[]. ${ }^{\text {355 }}$

It seems relatively clear that if the Secretary himself interprets Section $7(a)(2)$ as requiring an agency to consult, then that agency must consult. Therefore, a Supreme Court remedy that requires the Secretary to expand the scope of section 7(a)(2) consultations to include agency action affecting foreign projects would necessarily redress the plaintiffs' injury: lack of consultation on foreign projects. Furthermore, the argument that the requested remedy in Lujan passes constitutional muster becomes even stronger when one considers that the injury is to a procedural right-the right to consultation. ${ }^{356}$ As the Court in Lujan admits, a "person who has been accorded a procedural right to protect his concrete interests can assert that right without meeting all the normal standards for redressability. ${ }^{\$ 357}$

If the Court were solely considering the constitutional requirement of redressability, then the Court probably would have acknowledged that the plaintiffs satisfied the constitutional requirement. Once again, however, the Court imported other factors into the Article III limits. One major difference between Lujan and Hill is that Hill affected an action in Tennessee while Lujan affected an action on foreign soil. The Court may again be including international concerns in its constitutional analysis.

After the Court explained that it was an open question whether or not the federal agencies would consult with the Secretary, it proceeded to explain that even if the agencies did consult, it was still not likely that the plaintiffs' environmental injuries would be redressed. Since agency money provided only " $10 \%$ of the funding," there was no guarantee that a termination of American funding would terminate the foreign projects that threaten endangered species. ${ }^{358}$ However, the Court ignored the fact that many foreign governments had requested the assistance of Ameri-

actions").

${ }^{355}$ Lujan, 112 S. Ct. at 2155 (Blackmun, J., dissenting).

${ }^{356}$ See id. at 2142.

${ }^{357} \mathrm{Id}$. at $2142 \mathrm{n} .7$. In the Lujan case, the purpose of the consultation itself is to attempt to discern the environmental consequences of the proposed federal action. Requiring the plaintiff to make a significant showing of redressability on a procedural injury requires the plaintiff to "show much of what she claims should be investigated" by the consultation procedure itself. Fletcher, supra note 6, at 259.

${ }^{358}$ See Lujan, 112 S. Ct. at 2142. 
can agencies in funding projects, and these projects might not be able to continue without American support. ${ }^{359}$ "[I]t is not mere speculation to think that foreign governments, when faced with the threatened withdrawal of United States assistance, will modify their projects to mitigate the harm to endangered species. ${ }^{n 60}$

It is difficult to explain the Court's reasoning regarding the redressability issue in Lujan when one considers that the Court found that the plaintiffs in United States $v$. Students Challenging Regulatory Agency Procedures (SCRAP) ${ }^{361}$ demonstrated a causal link between the remedy and the injury. In $S C R A P$, a group of law students tried to enjoin a railroad freight rate increase approved by the Interstate Commerce Commission, basing their claim upon the National Environmental Policy Act ("NEPA"). ${ }^{362}$ The plaintiffs argued that the following chain of causation would lead to injury: the railroad would illegally increase its freight rate, the rate increase would discourage recycling (because recycled goods were transported on the railroad), the discouragement of recycling would lead to a decline in recycled goods, the decline in recycled goods would lead to an increase in litter, the increase in litter would lead to greater pollution, the greater pollution would decrease the quality of the air, the decreased air quality would harm the plaintiffs' interest in breathing unpolluted air. ${ }^{363}$ Despite the "attenuated line of causation to the eventual injury, ${ }^{n 64}$ the Court still granted standing. ${ }^{365}$

One could defend Lujan by claiming that SCRAP artificially lowered the constitutional redressability requirement. Indeed, many commentators have been very critical of the SCRAP decision. ${ }^{366}$

${ }^{359}$ See id. at 2157 (Blackmun, J., dissenting).

${ }^{360} \mathrm{Id}$. at 2149 (Stevens, J., concurring); see also id. at 2157 (Blackmun, J., dissenting) (noting that the withdrawal of American funding could "affect foreign government conduct sufficiently to avoid harm to listed species").

${ }^{361} 412$ U.S. 669 (1973).

${ }^{362} 42$ U.S.C. $\S \S 4321-4370$ (1988 \& Supp. III 1991). The SCRAP complaint was based upon an alleged violation by the ICC of $\S 4332(2)(C)$, which requires an environmental impact statement for legislation "affecting the quality of the human environment." 42 U.S.C. $\$ 4332(2)$ (C) (1988).

${ }^{363}$ See SCRAP, 412 U.S. at $676,678$.

${ }^{364} I d$. at 688 .

${ }^{365}$ See id. at 690 . One could argue that the Court only granted standing because of the decreased evidentiary requirements at the pleadings stage. However, the Court has tended to require a level that will satisfy summary judgment although the case is still at the pleadings stage. See supra note 315 .

${ }^{366}$ See DAvis, supra note 6, $\$ 24: 30$ at 324 ("If the Court were focused on creating law of standing that is rational and stable, . . it probably would have denied standing 
Nonetheless, Lujan itself does not seem to regard SCRAP as bad law. ${ }^{367}$ More importantly, Justice Scalia specifically used SCRAP to support a grant of standing while he was still with the District of Columbia Circuit. In Center for Auto Safety v. Ruckelshaus, ${ }^{368}$ a group of plaintiffs challenged an action by the EPA which temporarily permitted General Motors to exceed maximum pollution emissions standards under the Clean Air Act ${ }^{369}$ for cars already in use. Like the plaintiffs in SCRAP, the plaintiffs in Center alleged an injury to their interest in breathing clean air. Scalia granted standing by relying upon $S C R A P$. He dismissed the standing issue in a footnote:

The [plaintiffs] include two . . . not-for-profit organizations . . . and three private individuals .... The latter three assert that they are 'concerned about, and breathe[], pollutants in the ambient air' that would be increased by the agency action at issue .... [T] hese petitioners come within the broad grant of standing announced by the Supreme Court for such cases. ${ }^{370}$

It is unlikely that the Lujan Court, in an opinion also written by Justice Scalia, interprets SCRAP as totally bad law. ${ }^{371}$ This leaves one to wonder why the plaintiffs in SCRAP and Center received standing while the plaintiff in Lujan, who alleged a far less attenuated link to redressability, did not receive standing. Once more, the Court appears to be weighing factors beyond the proper scope of the constitutional analysis.

in SCRAP."); Chayes, supra note 6, at 20 ("[B]y no stretch of the imagination can it be said that the relief requested ... would necessarily result in lower rates."); Fletcher, supra note 6, at 259 ("SCRAP has come to be regarded as something of a sport.").

${ }^{367}$ Lujan actually uses SCRAP to support a proposition. See Lujan, 112 S. Ct. at 2139 (citing SCRAP for the proposition that a plaintiff's harm must be perceptible). Admittedly, Lujan does not rely upon SCRAP's reasoning. Nonetheless, if the Court in Lujan strongly disagreed with SCRAP, it could have used several other cases to support the proposition regarding the perceptibility of the plaintiff's harm. See, e.g., Warth v. Seldin, 422 U.S. 490, 501 (1975) (injury must be "distinct and palpable"); see also Allen v. Wright, 468 U.S. 737, 751 (1984) (similar analysis); Gladstone, Realtors v. Village of Bellwood, 441 U.S. 91, 100 (1979) (similar analysis).

368747 F.2d 1 (D.C. Cir. 1984) (Scalia, J.).

${ }^{369}$ See id. at 3; see also Clean Air Act Amendments of 1970, § 207, 42 U.S.C. $\S 7541$ (1988) (legislating compliance by vehicles and engines in actual use).

${ }^{370}$ Center, 747 F.2d at 3 n.2 (citation omitted).

${ }^{371}$ One could argue that Scalia, only a circuit court judge at the time, had no choice but to follow a Supreme Court standing decision. Even so, it seems that Scalia's attitude toward SCRAP is not entirely negative. See Perino, supra note 286, at 163-66 (discussing Scalia's ambiguous stance toward SCRAP). 


\section{What Makes a Concerm Prudential}

As discussed earlier, the justification behind the Article III standing barriers should be limited to the assurance of zealous advocacy. ${ }^{372}$ Other concerns such as separation of powers should not be encompassed by a constitutional doctrine because the courts and Congress must be given the chance to weigh factors which mitigate against the typical denial of standing in the presence of these other concerns. ${ }^{373}$ The three-pronged constitutional test simply does not support other concerns. Consider, for example, the bad fit between the constitutional test and the promotion of internationalism. In Lujan, the Court reasoned that the injury to the plaintiff was not imminent enough to confer standing. It has already been shown how the imminence requirement that the Court outlined may very well have been influenced by international concerns. ${ }^{374}$ Presumably the Court was hesitant to render a decision that would have a significant effect upon a foreign country's sovereignty. ${ }^{375}$ International concerns, however, should be completely independent of the imminence requirement. If Ms. Skilbred had a plane ticket to Sri Lanka reserved for the next day, she most likely would have satisfied the Court's imminence requirement. ${ }^{376}$ Nevertheless, a decision which grants standing in this hypothetical case would contain just as many international implications as a decision which grants standing to the actual plaintiff. A grant of standing to the hypothetical plaintiff is no less likely to intrude upon the foreign project than is a grant of standing in the actual case. The imminence of the injury to the plaintiff bears no relationship to the concern that the American judicial system is infringing on foreign countries.

The redressability requirement likewise is unrelated to international concerns. If the plaintiffs in Lujan had been able to show

372 See supra notes $34-46$ and accompanying text.

${ }^{373}$ See supra notes 47-65 and accompanying text (explaining how the inclusion of concerns such as separation of powers into the Article III analysis erroneously increases the constitutional barrier to standing, thereby preventing courts and Congress from weighing countervailing factors).

${ }^{374}$ See supra notes 303-19 and accompanying text (explaining that the different results in Lujan and Lucas are a result of the Court's importation of international concerns).

${ }^{375}$ See Blum, supra note 318 , at 132 (noting that the Secretary has argued against the application of $\$ 7$ to agencies acting abroad due to international worries).

${ }^{376}$ See Lujan, 112 S. Ct. at 2138 (requiring a "specification" of when Ms. Skilbred intended to return to Sri Lanka in order to establish injury). 
that the offending agency would definitely consult with the Secretary, and that this consultation would result in the elimination of any dangerous foreign construction projects, their injuries very likely would have been deemed redressable. This clearly redressable injury, however, would not mitigate the Court's concerns about infringing upon a foreign country's construction projects. Again, a grant of standing in the hypothetical case is no less likely to intrude upon foreign projects than is a grant of standing in the actual case. ${ }^{377}$

Similar analyses could be performed upon the Court's other imported nonconstitutional factors to reveal that they too are independent of injury and redressability. "In short, the [constitutional] tests formulated by the Supreme Court over the past quartercentury have been designed to measure the interest of the litigant." ${ }^{378}$ Like internationalism and separation of powers, ${ }^{379}$ the concerns of federalism ${ }^{380}$ and military deference ${ }^{381}$ are unrelated to the constitutional test.

If these four concerns are not part of the Article III analysis, then the question arises whether these concerns should even be considered as part of the prudential analysis. ${ }^{382}$ Prudential limitations encompass those concerns which suggest deference to

$s 77$ If anything, it would seem that the more redressable injury is actually more of an encroachment on a foreign nation's authority. A truly redressable injury by definition requires that a remedy exists which will result in the cessation of the foreign country's project. Such a hypothetical remedy is more likely to arouse international angers than a remedy of lesser redressability that does not necessarily cease the foreign country's projects.

${ }^{378}$ Nichol, supra note 33 , at 647 .

${ }^{379}$ See supra notes 47-67.

\$80 Consider a plaintiff who suffers a concrete, redressable injury at the hands of a state actor performing a core state function. Clearly, the plaintiff passes constitutional muster. Nonetheless, a grant of standing to this plaintiff would not alleviate federalism concerns any more than would a grant of standing to an uninjured plaintiff with no redressability who sues a state actor. Concerns over federalism are just as likely to be present whether or not the plaintiff satisfies the Article III requirements. See supra note 67 (explaining the poor fit between federalism and the three-pronged test).

${ }^{381}$ Consider a plaintiff who suffers a concrete, redressable injury at the hands of the military during a time of war. This plaintiff satisfies Article III. Again, a grant of standing to this plaintiff would not implicate military concerns any less than would a grant of standing to an uninjured plaintiff who sues the military. Concerns over military deference are just as likely to be present whether or not the plaintiff satisfies the Article III requirements.

${ }^{382}$ Recall that the standing requirement has two components-prudential and constitutional. See supra note 22-24 and accompanying text. If a concern is neither constitutional nor prudential, it should not be part of the standing question at all. 
"matter[s] of judicial self-restraint." ${ }^{383}$ The relevant question is not whether the court should consider the concern at all. Rather, the court must ask itself whether merely hearing the case implicates this concern, ${ }^{384}$ since "standing is a preliminary jurisdictional requirement." ${ }^{385}$ If so, the concern is properly prudential. If not, the court should only consider that concern if it hears the case on the merits.

Consider the concern of military deference. Courts will sometimes defer to the military when deciding cases involving military issues. ${ }^{386}$ Courts are reluctant, particularly in times of war, to suppress military judgment. ${ }^{387}$ Courts should consider this concern, however, only after it is clear that the plaintiffs have standing. In Schlesinger $v$. Reservists Committee to Stop the War, ${ }^{388}$ the Court seems to unnecessarily import concerns of military deference into its preliminary jurisdictional analysis. ${ }^{389}$ Since merely hearing the case would not have harmed the military, ${ }^{390}$

38313 WRIGHT, supra note $12, \S 3531$, at 345 .

${ }^{384}$ See id. (noting that prudential concerns relate to whether "it seems wise not to entertain the case"). A nonconstitutional concern that does not relate to the question of whether it seems prudent to hear the case is not a prudential concern and therefore should be removed entirely from the standing analysis.

International Primate Protection League v. Institute for Behavioral Research, Inc., 799 F.2d 934 (4th Cir. 1986), cert. denied, 481 U.S. 1004 (1987), provides an interesting example of a prudential concern. In Primate, the court denied standing to plaintiffs alleging injury under the Animal Welfare Act of 1970, 7 U.S.C. $\S \S 2131-$ 2159 (1988 \& Supp. IV 1992). The plaintiffs attempted to enjoin the National Institutes of Health from allowing future noxious treatment to a group of experimental monkeys. The court denied standing, however, because merely hearing the case "might open the use of animals in biomedical research to the hazards and vicissitudes of courtroom litigation." Primate, 799 F.2d at 935 . For a critical analysis of this decision, see Klauber, supra note 87.

385 Fletcher, supra note 6 , at 223.

${ }^{386}$ For examples of such cases, see infra note 390.

${ }^{387}$ See supra note 221 (discussing Korematsu v. United States, 323 U.S. 214 (1944)); see also Hirabayashi v. United States, 320 U.S. 81, 93 (1943) (holding that congressional and executive action was constitutional because it "must be appraised in the light of the [wartime] conditions"); DILLON S. MYER, UPROOTED AMERICANS 259 (1971) (discussing the probable constitutionality of issues that "could be considered to be a military necessity").

${ }^{388} 418$ U.S. 208 (1974).

${ }^{389}$ See supra notes $220-21$ and accompanying text (discussing how Schlesinger probably imported military concerns into the constitutional analysis).

${ }^{390}$ There is no evidence to suggest that merely hearing Schlesinger, a case concerning the constitutionality of allowing members of Congress to be in the military reserve, would adversely affect the military. In fact, the Court often uses the merits to defer explicitly to the military in times of war. See, e.g., Korematsu, 323 U.S. at 214, 233-34 (upholding the constitutionality of a presidential executive order issued 
the Court could have addressed these concerns on the merits. When hearing the case does not, in and of itself, implicate concerns for military deference, these concerns should not be assimilated into the standing analysis.

Military deference, however, should be distinguished from the concerns of federalism, separation of powers, and internationalism. Whereas merely hearing the case does not implicate concerns about proper deference owed to the military, hearing the case does, for example, implicate concerns about proper deference owed to state governments. When a federal court grants standing in a case that involves state actors, it automatically places the fate of the state actors under the control of the federal judiciary. Merely allowing a part of the federal government to determine the fate of state officials implicates concerns of federalism. "[R]ecognition of the need for a proper balance in the concurrent operation of federal and state [governments] counsels restraint" against the federal courts hearing cases involving state officers. ${ }^{391}$ Standing's prudential limitations must account for concerns about federalism.

A similar restraint is necessary for cases that implicate concerns about internationalism and separation of powers. As for internationalism, merely hearing a case could potentially inflame international tensions. ${ }^{392}$ Consequently, the prudential limits should take into account such concerns. Similarly, merely hearing a case could create separation of powers concerns. Courts usually deny standing to "generalized grievances" because such grievances typically affect enough of the population that they would be more appropriately redressed by the representative branch than by the unelected judiciary. ${ }^{393}$ Merely hearing the case allows the courts to assume a role which is more properly assumed by Congress. The prudential limits of standing may properly consider separation of powers

during World War II that forced Japanese Americans to evacuate their homes); Hirabayashi, 320 U.S. at 93 (sustaining a World War II curfew order that required all persons of Japanese ancestry to remain in their homes after 8 p.m.).

${ }^{391}$ O'Shea v. Littleton, 414 U.S. 488, 499 (1974).

${ }^{392}$ See supra notes 318,320 and accompanying text (noting the judicial concern for avoiding arousal of international tensions).

${ }^{393}$ See Logan, supra note 23, at 47 ("In a democracy, questions that aggrieve large portions of the people are best handled by their elected representatives, who possess political legitimacy as well as the special factfinding and policymaking capabilities necessary to address broad questions of public policy."); Poisner, supra note 25, at 355 (explaining that "some injuries are so widely shared" that judicial review is inappropriate); supra note 294 and accompanying text (citing cases which discuss the proper role of the Court in a democratic society). 
concerns and thereby "minimize the role of the judiciary in a democratic society." 394

As the preceding discussion indicates, concerns about separation of powers, federalism, and internationalism do have a proper place in the standing analysis. However, because these concerns distort the constitutional part of the standing analysis, they should be considered only in the prudential part of the analysis. By routinely importing these concerns into the constitutional analysis, the Court has created a number of damaging consequences.

\section{CONSEQUENCES}

\section{A. Harm to Courts}

While prudential considerations often militate in favor of judicial restraint, "countervailing considerations may outweigh the concerns underlying the usual [prudential] reluctance to exert judicial power. ${ }^{\prime 395}$ Since the courts have no discretion to override constitutional limits, ${ }^{396}$ Supreme Court decisions, which import what should be prudential considerations into the constitutional analysis, deprive the courts of the opportunity to weigh the countervailing considerations. The result is a call for judicial restraint in virtually all circumstances.

A question arises as to whether the increased constitutional limits actually decrease judicial discretion. After all, although the importation of prudential concerns into the constitutional mix will theoretically decrease discretion, it may seem that the lower courts would still be able to distinguish cases where factors such as internationalism or federalism are implicated from cases where such factors are not implicated. The case law, however, suggests otherwise. The lower courts seem unwilling to override increased constitutional limits, despite the presence of factors which alleviate the normal concern over a grant of standing.

In American Postal Workers Union v. Frank, ${ }^{397}$ a labor union waged a Fourth Amendment challenge to a U.S. Postal Service policy that called for mandatory drug testing of job applicants. ${ }^{398}$

${ }^{394}$ Poisner, supra note 25 , at 354 .

${ }^{395}$ Warth v. Seldin, 422 U.S. $490,500-01$ (1975).

396 See supra note 25 and accompanying text (giving sources which explain that courts can grant standing only if Article III permits).

${ }^{397} 968$ F.2d 1373 (1st Cir. 1992).

${ }^{398}$ See id. at 1374. 
The union asked for declaratory and injunctive relief that would prevent the Postal Service from future testing. ${ }^{399}$ The court denied standing, ${ }^{400}$ relying in part on City of Los Angeles v. Lyons. ${ }^{401}$ It held that while the union members may have claims for damages due to the coerced testing they already endured, there is no case or controversy with respect to the future possibility of coercion. " $[\mathrm{P}]$ ast exposure to harm will not ... confer standing upon a litigant to obtain equitable relief '[a]bsent a sufficient likelihood that he will again be wronged in a similar way." 402

The union attempted to distinguish its case from Lyons by pointing to the fact that the future injury in Lyons-an illegal chokehold-was unlikely to recur whereas the future injury in Frank-a coerced drug test-was extremely likely to recur because the Postal Service continued to impose preemployment drug testing on job applicants. The court responded that since the plaintiff union was composed only of current employees, none of its members faced any likelihood of future exposure to illegal conduct. "Because the drug testing policy is applied only to job applicants, no Union member faces a realistic risk of future exposure to it." ${ }^{403}$

The court's comparison to Lyons is a valid one. The probability that the union's members would face coerced testing in the future was probably no greater than the probability that Lyons would face future chokeholds. Nevertheless, as previously demonstrated, the possibility of future injury to Lyons actually may have been substantial. ${ }^{404}$ Similarly, Postal Service practices suggest that the plaintiff's members could quite easily be exposed to future coercion. Since the union represents some employees who were not tested before they were hired, ${ }^{405}$ and since the Postal Service "consistently imposes" a policy of testing all employees at one time or another, ${ }^{406}$ it is more than speculative that the untested members of the

${ }^{999}$ See id.

${ }^{400}$ See id. at 1378.

401461 U.S. 95 (1983).

402 Frank, 968 F.2d at 1376 (quoting Lyons, 461 U.S. at 111).

${ }^{403} \mathrm{Id}$. at 1377.

${ }^{104}$ See supra notes 234-38 and accompanying text (citing evidence that the injury to the plaintiff in Lyons was not speculative).

405 See Frank, 968 F.2d at 1374 (noting that "[s]ome of [the union's members] underwent drug testing before they were hired"). The fact that only some members underwent testing before they were hired implies that some members did not undergo testing before they were hired.

${ }^{406} I d$. at 1377 . While it is true that the Postal Service tested only job applicants, none of whom were in the union, the fact that the Postal Service performs "drug 
plaintiff union may be mandatorily tested some day. These members probably will be tested eventually but will be deprived of the opportunity to challenge the constitutionality of the testing.

One cannot fault the First Circuit for its decision. If the Supreme Court in Lyons could hold that the injury to Lyons was too speculative to pass constitutional muster, then it is certainly reasonable for the circuit court in Frank to hold that the injury to its plaintiffs was not sufficiently likely either. The only problem is that it is completely plausible that Lyons did possess the constitutionally required level. ${ }^{407}$ Indeed, "[i]t is inconceivable . . . that Lyons asserted no particularized harm. ${ }^{208}$ The Court imported federalism into its constitutional analysis, thereby artificially inflating the constitutional minimum.

The Lyons Court could have both maintained the proper constitutional level and still denied standing based on federalism concerns by explicitly relying on this concern in its prudential analysis. If it had, future courts such as the one in Frank-whose plaintiffs possess the constitutional minimum-could grant or deny standing based upon the presence or absence of countervailing prudential considerations such as federalism. If deference to state practices suggests a denial of standing, courts could so choose. If, as the court in Frank explicitly admits, "the issue . . may be more appropriate for federal court," 409 then the court could grant standing. ${ }^{410}$ Lower courts would be able to weigh countervailing situations. The Lyons decision, however, removed such discretion from the courts by importing the prudential requirement of federalism into the constitutional analysis. Since the lower courts have no discretion with respect to such constitutional limits, the Supreme Court removed these issues from the purview of the lower courts. Even though the court in Frank noted that the case might

testing on a daily basis" suggests that the Postal Service could very likely test its previously untested employees at some time soon. Id. Indeed, the plaintiffs describe the possibility of "a very real and substantial conflict" with the Postal Service. Id.

${ }^{407}$ See supra note 236 and accompanying text (explaining that the injury to Lyons probably satisfied the constitutional requirement).

${ }^{408}$ Nichol, supra note 6, at 100.

${ }^{409}$ Frank, 968 F.2d at 1377 n.5.

${ }^{110}$ Presumably the Frank case is more appropriate for the federal courts than Lyons because the plaintiff is challenging the conduct of a national organization, the Postal Service, as opposed to a state organization such as the Los Angeles Police Department. In the case of a national organization, there is no need for deference to principles of federalism. 
have been more appropriate for federal court because no federalism concerns were implicated, it still had to deny standing. ${ }^{411}$

Just as the Lyons case deprived the Frank court of its power to examine mitigating factors, the Court in Allen $v$. Wright ${ }^{412}$ deprived the court in Haitian Refugee Center $v$. Gracey ${ }^{413}$ of the same power. In Gracey, the Haitian Refugee Center ("HRC") brought an action challenging an executive program which ordered the interdiction of certain vessels carrying undocumented aliens. ${ }^{414}$ The HRC claimed an injury to its interest in dealing with and promoting the well-being of Haitian refugees. ${ }^{415}$ The court denied standing, holding that the HRC failed to satisfy the redressability prong of the standing inquiry. ${ }^{416}$

The court's reasoning relied quite heavily upon the rationale of Allen: "With [the analysis of Allen] in mind, ... it is necessary to consider whether [the HRC] ha[s] established" redressability. ${ }^{417}$ It should be no surprise, then, that the plaintiffs failed to satisfy this prong. As established earlier, Allen increased the redressability requirement by importing into this prong what should be the prudential concern of separation of powers, ${ }^{418}$ thereby denying standing despite the fact that the plaintiffs satisfied traditional notions of redressability. ${ }^{419}$

Similarly, the HRG's claim seems to be redressable. As the dissent explained, '[ $t$ ]here can be no doubt that [the HRC's] injury is fairly traceable to the [government's] actions. ${ }^{\text {"420 }}$ The HRC's ability to receive Haitian referrals "was cut off solely because of the interdiction ... and the relief sought would restore the flow. ${ }^{n 421}$

${ }^{111}$ See Frank, 968 F.2d at 1377 n.5, 1378 (explaining that while the issue at hand may have been more appropriate for federal court, the federal court system is "not the proper forum to press such claims unless the requirements for entry . . . are satisfied" (quoting Lyons, 461 U.S. at 112)).

112468 U.S. 737 (1984).

113809 F.2d 794 (D.C. Cir. 1987).

114 See id. at 796.

415 See id. at 799.

116 See id. at 801 . Actually, the court specifically discusses causation, but the two requirements are effectively equivalent. See supra notes 130,145 and accompanying text.

${ }^{417} I d$. at 806.

${ }^{418}$ See supra notes 271-72, 278 and accompanying text (discussing Allen's explicit importation of separation of powers into Article III).

${ }^{\$ 19}$ See supra notes 273-78 and accompanying text (citing evidence that the plaintiff's injury was probably redressable).

${ }^{120} \mathrm{Id}$. at 826 (Edwards, J., dissenting).

121 Id. 
Incredibly, even the majority admits that statistically it is "rather farfetched to deny the heavy probability that" the relief sought would redress the injury. ${ }^{422}$

Despite what appears to be clear redressability, the court denied standing. Although the court is admittedly unable to undertake a "pure analy[sis] of [redressability] ${ }^{\text {n23 }}$ due to the constraints of Allen, these constraints would not be necessarily problematic if the concern which drove Allen to increase the redressability requirement (i.e., separation of powers) also manifested itself in Gracey. It is at least arguable, though, that these concerns are mitigated in Gracey. ${ }^{424}$ The Supreme Court's treatment of redressability in Allen prevents the lower court from considering such mitigating factors.

The Frank and Gracey cases illustrate how the Supreme Court's overreaching constitutional analysis prevents the lower courts from examining countervailing issues, thereby harming the courts when these issues militate in favor of granting standing. Moreover, since Lujan extends the constitutional analysis further than any of its predecessors into what should be prudential considerations, ${ }^{425}$ it could potentially infringe quite detrimentally upon judicial discretion. Indeed, the effects of Lujan are already apparent.

When a court has granted standing after Lujan, it has done so hesitantly. ${ }^{426}$ In Animal Protection Institute of America v. Mosbacher, ${ }^{427}$ the court ultimately did decide to hear the merits, but only after lengthy deliberation. ${ }^{428}$ In Mosbacher, the plaintiffs, wildlife protection organizations, sought the invalidation of a permit issued

422 Id. at 806.

$423 \mathrm{Id}$. at 803.

424 See id. at 827 (Edwards, J., dissenting) (arguing that amply satisfying the traditional redressability prong, as the plaintiffs in Gracey do, serves to alleviate any worries over separation of powers).

${ }^{425}$ See Snake River Farmers' Ass'n, Inc. v. Department of Labor, 9 F.3d 792, 799 (9th Cir. 1993) (Goochever, J., dissenting) ("In Lujan, the Supreme Court heightened the requirements for an injury sufficient for Article III standing . . .."); supra notes 286-292 and accompanying text (noting how Lujan imports what should be prudential concerns into both injury and redressability).

${ }^{426}$ See, e.g., Christian Knights of the Ku Klux Klan Invisible Empire, Inc. v. District of Columbia, 972 F.2d 365, 371 (D.C. Cir. 1992) ("[T] the Supreme Court's recent decision" in Lujan.); see also id. ("W]e would not jump out of our chairs in surprise were the Court to reverse the decision.").

427799 F. Supp. 173 (D.D.C. 1992).

${ }^{428}$ See id. at 177 (" $[\mathrm{T}]$ he Court concludes (although not without certain misgivings ...), that petitioners . . . have standing to oblige the Court to proceed to address the merits of their claims."). 
by the Secretary of Commerce to an aquarium owner allowing the owner to import whales from the natural environment. ${ }^{429}$ The plaintiffs contended that the Secretary violated the Marine Mammal Protection Act of $1972^{430}$ by failing to make certain factual determinations before issuing the permit. ${ }^{431}$ The organization claimed an injury to its interest in watching whales in their natural environment. ${ }^{432}$ The court, noting the specific nature of the injury, granted standing. ${ }^{433}$ It used a factually similar Supreme Court decision, Japan Whaling Association v. American Cetacean Society, ${ }^{434}$ to bolster the proposition that a denial of the opportunity to watch whales constitutes a cognizable injury. It explained that " $[\mathrm{j}] \mathrm{ust}$ a few terms ago ... the Supreme Court held that 'whale-watchers' ... allege a sufficient 'injury in fact" if they are denied the opportunity to watch whales. ${ }^{435}$ The court then ultimately granted standing, noting that the plaintiffs satisfied Lujan's imminence requirement through the existence of concrete plans. ${ }^{436}$

However, even though the court granted standing in Mosbacher, it did so reluctantly. ${ }^{437}$ It is at least arguable that a major factor that influenced the Mosbacher court in its decision to grant standing, despite its pronounced misgivings, is the remarkable similarity of Japan Whaling. ${ }^{488}$ The Mosbacher court's overarching reliance on a coincidentally similar Supreme Court decision suggests that without such support the lower courts will not grant standing, due to a feared lack of discretion.

In Madsen v. Boise State University, ${ }^{439} \mathrm{John}$ Madsen sued the university claiming that it had illegally discriminated against him on

129 See id. at 175.

430 16 U.S.C. § 1361 (1988 \& Supp. IV 1992).

4 See Mosbacher, 799 F. Supp. at 175.

492 See id. at 176.

435 See id. at 177 .

454478 U.S. 221 (1986). In Japan Whaling, the Supreme Court held that whale watchers who were similarly situated to those in $M$ osbacher did have standing to allege an injury to an interest in watching whales. See id. at 230-31 n.4.

${ }_{435}$ Mosbacher, 799 F. Supp. at 176 (quoting Japan Whaling, 478 U.S. at 231 n.4).

${ }^{436} \mathrm{See} i d$. at 177 (holding that the plaintiffs "meet the test" for proving imminence). The court, in establishing this point, noted just how specific the plaintiffs' plans were. See id. ("Doncaster plans to watch belugas 'this summer'; Morlan plans to take students to watch belugas in the 'summers of 1993 and 1994'; and Nancy Daves plans to visit Japan to watch false killer whales 'this summer.').

${ }^{437}$ See supra note 428 and accompanying text.

${ }^{438}$ See Mosbacher, 799 F. Supp. at 176 (noting that plaintiffs in both cases were "whale-watchers").

${ }^{439} 976$ F.2d 1219 (9th Cir. 1992). 
the basis of a handicap. ${ }^{440}$ While some non-handicap parking spots on campus did not require a permit, and therefore were free of charge, every handicap spot on campus did require both a permit and a fee. ${ }^{41}$ Madsen made several phone calls to the parking services office to inquire about the possibility of obtaining a free permit and was told none were available. ${ }^{442}$ Madsen then sued the university. On appeal, the court held that Madsen did not have standing to bring the suit, ${ }^{443}$ reasoning that since the plaintiff had never formally applied for a free permit, he could not be adequately distinguished from those who wanted to see the law correctly resolved for its own sake. ${ }^{444}$ "The formal application ... presents a bright line separating those who have suffered from the challenged policy and those who have not. ${ }^{n 45}$ However, Madsen could be clearly distinguished from the general population without the requirement of an application and therefore should have been granted standing. ${ }^{46}$ He called the university several times asking for a free spot and "was told he would have to pay the fee." ${ }^{\text {447 }}$ It is not clear why formally applying for a spot would distinguish Madsen any more than calling several times and asking for a spot over the phone.

It is difficult to miss the influence of Lujan on Madsen. Lujan required the plaintiff to show "concrete plans" which amounted to an exact "specification of when the some day [for a return trip] will be." 448 Madsen required the plaintiff to make a "concrete re-

440 See id. at 1220 .

411 See id.

$\$ 42$ See id.

143 See id.

444 See id.

${ }^{415} I d$. at 1222. The court used the formal application as the means of verifying personal stake.

446 The majority would argue with this assertion, as it cited Moose Lodge No. 107 v. Irvis, 407 U.S. 163, 166-71 (1972) for the proposition that a "plaintiff who had never applied for membership lacked standing to challenge [a] fraternal organization's discriminatory membership policies." Madsen, 976 F.2d at 1220.

However, as the dissent points out, "there was no evidence that [the plaintiff in Moose Lodge] wanted to be a moose; not everyone does." Id. at 1224 (Norris, J., dissenting) (quoting Planned Parent Ass'n v. Kempiners, 700 F.2d 1115, 1136 (7th Cir. 1983) (Posner, J., concurring)). Conversely, there can be no doubt that Madsen wanted a parking spot. See Madsen, 976 F.2d at 1224 (Norris, J., dissenting) (arguing that Madsen made it "clear to the University that he wanted free disabled parking").

${ }^{417}$ Id. at 1224 (Norris, J., dissenting).

${ }^{48}$ Lujan, 112 S. Ct. at 2138. 
quest" 449 which amounted to "requiring a formal application as the normal prerequisite for bringing a case to court." ${ }^{n 40}$ Yet neither of these requirements, designed at least in part to ascertain which plaintiffs show the necessary personal stake, ${ }^{451}$ allows for the fact that a litigant could show personal stake without satisfying these formalistic ${ }^{452}$ requirements. It was already explained how the plaintiffs in Lujan demonstrated evidence of personal stake. ${ }^{453}$ Similarly, Madsen showed evidence of personal stake by continually calling the parking office. Neither litigant, however, was granted standing.

The Court in Lujan imported the concern of separation of powers into its constitutional personal stake requirement, thereby increasing the constitutional minimum. ${ }^{454}$ However, the separation of powers issue is not implicated in Madsen to the same extent that it was implicated in Lujan. Yet the lower court is forced to deny standing because the court must show deference to Lujan's "constitutional requirement." ${ }^{455}$ If the Court in Lujan had specifically denied standing based on the prudential limitation of separation of powers, while acknowledging that the plaintiffs satisfied Article III, then future courts, such as the one in Madsen, could have used their discretion in considering whether separation of powers concerns were implicated. If a plaintiff both satisfied the constitutional requirement and did not exacerbate the prudential concerns explicitly outlined by the Supreme Court, a lower court would have been able to grant standing.

Indeed if the Lujan Court had properly analyzed the case, the Court of Appeals would probably have granted standing to Madsen. The particular factual circumstances of this case present countervail-

49 Madsen, 976 F.2d at 1221.

${ }^{450} I d$. at 1222.

${ }^{451}$ Recall that the requirement of concrete plans in Lujan seems to be related both to imminence and personal stake. For a discussion of the imminence requirement, see supra notes 121-29 and accompanying text. For a discussion of the personal stake requirement, see supra notes $91-114$ and accompanying text.

452 It is no coincidence that the dissent in each case refers to the Court's personal stake requirement as formalistic. See Lujan, 112 S. Ct. at 2153 (Blackmun, J., dissenting) (referring to the Court's requirement of "detailed descriptions of future conduct" as "formalism"); Madsen, 976 F.2d at 1224 (Norris, J., dissenting) (referring to the court's application requirement as "formalism" (quoting Lee v. Weisman, 112 S. Ct. 2649, 2659 (1992))).

153 See supra notes $332-35$ and accompanying text.

454 See supra notes $336-39$ and accompanying text.

${ }^{455}$ Madsen, 976 F.2d at 1222. Madsen cites Lujan when considering the constitutional standing requirement. See id. 
ing considerations which outweigh the normal separation of powers concerns. Justice Powell has stated the principle that separation of powers concerns are minimized when the Court must protect "minority groups against ... discriminatory government action. ${ }^{356}$ It is certainly conceivable that handicapped citizens are a minority group which deserve a high level of Court protection. ${ }^{457}$ Therefore, separation of powers concerns are greatly reduced. Madsen, a case involving a handicapped American citizen, implicates few of the separation of powers concerns seen in Lujan. ${ }^{458}$ Yet the Court's importation of what should be prudential concerns results in the denial of standing in Madsen.

Snake River Farmers' Association, Inc. v. Department of Labor ${ }^{459}$ is another case where Lujan's inclusion of what should be prudential concerns into the Article III requirement of imminence precludes lower courts from properly weighing countervailing factors. In Snake River, the Department of Labor established regulations which limited the conditions upon which farmers could employ foreign farmworkers. ${ }^{460}$ One of the potential foreign farmworkers who was in the process of searching for work sued the Department of Labor, alleging that the Department's burdensome requirement of a personal reference would cause injurious delays in the process of finding a job. ${ }^{461}$

The court denied standing, reasoning that "the possibility that [the plaintiff] might seek ... employment ... was insufficiently concrete to make his injury from [the delays] 'actual or immi-

${ }^{456}$ United States v. Richardson, 418 U.S. 166, 192 (1974) (Powell, J., concurring); see also Scalia, supra note 8, at 894 (discussing the Court's "traditional undemocratic role of protecting ... minorities against impositions of the majority"). Professor Tribe argues that a grant of standing is advisable when the nature of the injury is such that "the effective operation of majoritarian processes" is inhibited. TRIBE, supra note $42, \S 3-18$, at 129 .

${ }_{457}$ See TRIBE, supra note 42, §16-31, at 1595-96 (“[C]ourts [have] begun to realize that . . . the disabled have been systematically excluded . . . ."); see also School Bd. v. Arline, 480 U.S. 273, $284-86$ (1987) (granting broad protection to handicapped individuals).

${ }^{458}$ Unlike handicapped citizens, it is difficult to view environmental groups as a minority that need Court protection. Several sources even argue that environmental groups are quite exploitative. See, e.g., Scalia, supra note 8, at 897 (describing courts' "strict enforcement of the environmental laws" as a sign of class bias); Michael S. Greve, The Private Enforcement of Environmental Law, 65 TUL. L. REv. 339, 341-42 (1990) (claiming that environmental groups amount "to an environmentalist enforcement cartel").

${ }^{459} 9$ F.3d 792 (9th Cir. 1993).

${ }^{460}$ See id. at 794.

${ }^{461}$ See id. at 796. 
nent." ${ }^{462}$ It is likely, however, that the plaintiff would have satisfied the imminence requirement if not for Lujan. The plaintiff had a past history of applying for jobs at a frequent pace. There is no reason to assume that he would not apply again at some time in the near future. Indeed, the plaintiff's "continued attempts to find [a] ... job ... put him at a genuine risk of future injury from the [personal reference] requirements." ${ }^{\$ 63}$

The court could not grant standing, though, since it was hampered by the fact that "[i]n Lujan, the Supreme Court heightened the requirements for finding an injury in fact sufficient for Article III standing. ${ }^{464}$ The consequence of this heightening is that the Snake River court is precluded from weighing the presence of prudential factors such as internationalism. As was already explained, Lujan imported the concern of internationalism into the imminence requirement. ${ }^{465}$ If Lujan had denied standing due to international worries by using the prudential barrier, the Snake River court could have considered the presence or absence of international worries. In all likelihood, it would have reasoned that international concerns would militate toward hearing the case. While a grant of standing in Lujan could arouse international tensions, ${ }^{466}$ a grant of standing in Snake River would probably reduce international tensions, since it would allow United States employers potentially to employ foreign workers. ${ }^{467}$ Nonetheless, Lujan's heightened imminence requirement prevents the Snake River court from considering such mitigating factors.

Christian Knights of the Ku Klux Klan Invisible Empire, Inc. $v$. District of Columbia ${ }^{468}$ is another case affected by Lujan, even though it had little to do with standing. In $K K K$, twenty-seven Klan members paraded in Washington, D.C. from the Washington Monument to Capitol Hill. ${ }^{469}$ Counter-demonstrators resisted the members, ruining the march. ${ }^{470}$ The Klan then requested a permit from the police for a new march. ${ }^{471}$ The police granted

${ }^{162}$ Id. at 797 (quoting Lujan, 112 S. Ct. at 2136).

${ }^{163}$ Id. at 799 (Boochever, J., dissenting).

${ }_{164}$ Id.

${ }^{465}$ See supra notes 313-18 and accompanying text.

${ }^{466}$ One of the relevant locations is Sri Lanka. See Lujan, 112 S. Ct. at 2138.

${ }^{467}$ See Snake River, 9 F.3d at 794 (noting the presence of a foreign plaintiff who sought employment in the United States).

468972 F.2d 365 (D.C. Cir. 1992).

${ }^{469} \mathrm{See} i d$. at 367 .

${ }^{470}$ See id.

${ }^{171}$ See id. 
the permit but limited the location of the parade route. ${ }^{42}$ The $\mathrm{Klan}$ brought an action for an injunction which would require the police to allow a march on the preferred location. ${ }^{473}$ Ultimately, the District Court granted the injunction. ${ }^{474}$ The defendants appealed. However, since they "did not seek an emergency appeal," the march occurred before appellate review could be granted. ${ }^{475}$ The issue for the circuit court was whether the appeal was moot because the march had already occurred. ${ }^{476}$

When deciding whether an issue is moot, one criterion advanced by the Supreme Court to be considered is whether the issue is "capable of repetition." ${ }^{477}$ If the issue is capable of repetition, it is not moot. "By 'capable of repetition' the Supreme Court ... means 'a reasonable expectation that the same complaining party would be subjected to the same action again." 478

It is important to keep in mind that the requirement of "capable of repetition" has never been limited by the requirement of imminence. The Supreme Court has explicitly stated that an issue is not moot if the events are "capable of repetition 'at any time." 479 The imminence limitation on standing has had no corollary in the doctrine of mootness. Indeed, the Court "has not so much as hinted at such a limitation. ${ }^{\text {480 }}$ Therefore, the court did not dismiss for mootness and ultimately decided that the Klan would "make its way into the city again" and that the original event was clearly capable of repetition. ${ }^{481}$ Even so, the lower court was quite concerned that Lujan's manipulation of imminence could very well be transported into mootness. It admitted that it "would not jump out of [its] chairs in surprise were the Court to say that 'capable of repetition' means imminent repetition." ${ }^{482}$ The circuit

\footnotetext{
472 See id. at 368 .

${ }^{473}$ See id.

474 See id.

475 Id. at 369 .
}

${ }^{476}$ See $i d$. Despite the fact that the march already occurred, the litigants brought the case to appeal because "the Klan and the District want[ed] to bring the merits of the case to an appellate conclusion." Id. (1911)).

${ }^{177}$ Id. at 369 (quoting Southern Pac. Terminal Co. v. ICC, 219 U.S. 498, 515

${ }^{478}$ Id. at 371 (quoting Weinstein v. Bradford, 423 U.S. 147, 149 (1975) (per curiam)).

${ }^{479}$ Id. (quoting Washington v. Harper, 494 U.S. 210,219 (1990)).

$480 \mathrm{Id}$. at 371 .

${ }^{481} I d$.

${ }^{482} I d$. 
court was legitimately concerned that there could be a new requirement after Lujan. After all, the Court in Lujan did "place[] great weight" on the requirement of imminence. ${ }^{483}$

It is still startling, however, that the Court even contemplated not hearing the case. The fact that "hardly a week goes by in which [the Klan] do[es] not conduct a street walk" suggests an overwhelming likelihood that the event would be repeated. 484 The court itself was "confident that eventually [the Klan] [would] make its way into the city again. ${ }^{n 85}$ Prior to Lujan, this would have been a clear case of a claim that was not moot. ${ }^{486}$ However, after the Gourt in Lujan distorted the imminence requirement for standing, ${ }^{487}$ the court in $K K K$ legitimately feared that this increased imminence requirement would also be applicable to mootness. ${ }^{488}$ Moreover, if the constitutional distortion of Lujan could transcend standing and reach into mootness, it is plausible that the distortions in Lujan could reach into other areas of the law as well. ${ }^{489}$

An explicit separation of constitutional and prudential considerations in Lujan would have eliminated this concern. If the Lujan Court had imported the prudential concern of internationalism into its constitutional analysis, ${ }^{490}$ the constitutional requirement of imminence would not have been extended to such an unprecedented and unreasonable level. The requirement of imminence would have been limited exclusively to the constitutional analysis, thus eliminating all ambiguity and confusion. If such a distinction had been made in Lujan, the court in $K K K$ would not have had to question whether the heightened imminence requirement referred to mootness. $K K K$ would have been heard on its merits without hesitation or debate because no international concerns were implicated. ${ }^{491}$ The Lujan Court has extended the constitutional

${ }^{483} \mathrm{Id}$.

484 Id. at 370 (quoting Declaration of Virgil L. Griffin, Imperial Wizard of the Ku Klux Klan, at 2, I 4 (Oct. 21, 1990)).

485 Id. at 371 .

${ }^{486}$ See id. at 370-71 (discussing previous mootness case law suggesting that the current dispute would be capable of repetition).

${ }^{487}$ See supra notes 309-12 and accompanying text (discussing the discrepancy in the imminence requirement in Lucas and Lujan).

${ }^{488}$ See supra note 482 and accompanying text.

${ }^{489}$ See Marshall J. Breger, Defending Defenders: Remarks on Nichol and Pierce, 42 DUke L.]. 1202, 1215 (1993) ("It is also conceivable that [Lujan] could lead the court to rethink the ripeness doctrine ....").

190 See supra text accompanying notes 313-18 (discussing Lujan's importation of internationalism into the constitutional discussion).

491 The scheduled Klan march occurred in Washington, D.C. See KKK, 972 F.2d 
requirement by failing to limit its constitutional concerns to the three-pronged test. Consequently, the extension of the constitutional requirement has eliminated much of the lower courts' discretion.

\section{B. Harm to Congress}

In addition to the elimination of lower courts' discretion, the previous case law has also caused considerable damage to the powers of Congress. When the Court includes what should be prudential concerns in its constitutional analysis, it takes away Congress's discretion to weigh countervailing considerations in its decision-making process. ${ }^{492}$ Since Congress only has the power to create standing on prudential grounds, ${ }^{493}$ cases which remove what should be prudential limits and place them into the Article III analysis greatly restrict congressional power.

The Lujan case exemplifies this problem. When Congress drafted the ESA, it created a citizen-suit provision which provides that "any person may commence a civil suit on his own behalf ... to enjoin any person, including the United States and any other governmental instrumentality or agency ... who is alleged to be in violation [of the act]. ${ }^{n 494}$ The purpose of such a provision is to enable the private sector to help Congress in the enforcement of environmental laws. ${ }^{495}$ While Congress cannot confer standing upon a citizen who would otherwise be powerless to sue under Article III, ${ }^{496}$ it can use its powers to authorize any litigant who satisfies the requirements of Article III to bring a suit. ${ }^{497}$ The citizen-suit provision of the ESA should eliminate any concerns that should be prudential such as separation of powers or internationalism. ${ }^{498}$ Indeed, both of these concerns are exactly the type of

at 367.

492 For a discussion of why Congress should have the power to make certain broad decisions, see supra notes 59-65 and accompanying text.

${ }^{993}$ See supra note 25 (explaining that Congress can grant standing only as far as Article III permits).

${ }^{494}$ Pub. L. No. 93-205, 87 Stat. 884 (1973) (codified as amended at 16 U.S.C. § 1540 (g) (1988)).

${ }^{495}$ See Greve, supra note 458 , at 342 (noting that the citizen-suit provision allows Congress to receive assistance from "private attorneys general").

${ }^{96}$ See McClure v. Carter, 513 F. Supp. 265, 271 (D. Idaho 1981) (noting that Congress cannot grant standing by a statute that is inconsistent with Article III).

${ }^{497}$ See Trafficante v. Metropolitan Life Ins. Co., 409 U.S. 205, 209-10 (1972) (explaining that Congress can grant standing as broadly as Article III permits).

${ }^{498}$ See Bullock, supra note 27 , at 615 ("Citizen suit provisions are . . . a legislative overruling of all prudential standing limitations."). 
problem that the citizen-suit provision of the ESA was designed to remedy.

The citizen-suit provision of the ESA was drafted to eliminate international concerns. When Congress enacted the ESA, one of its intentions was to allow suits which addressed agency activity in foreign nations. Indeed, "the consultation requirements of section 7 [were intended] to apply to federal actions abroad." 499 Such an intention obviates the need for judicial restraint involving international concerns. Additionally, the citizen-suit provision of the ESA eliminates separation of powers concerns as well. It was already explained how a congressional grant of standing, such as a citizen suit, alleviates separation of powers worries merely because it is the majoritarian Congress that is granting standing. ${ }^{500}$ When Congress drafted the citizen-suit provision of the ESA, it made a majoritarian decision to let the countermajoritarian courts resolve certain matters, thereby mitigating separation of powers concerns. ${ }^{501}$

When the Court in Lujan, however, dismissed the congressionally authorized citizen-suit due to separation of powers, it denied Congress its ability to override prudential worries and authorize standing, despite the fact that a congressional grant of standing alleviates worries over separation of powers. The Lujan Court would respond to the argument that it abridged Congress's ability to grant standing by making two arguments of its own. First, it would note that it did not abridge congressional power because it did not deny the citizen suit due to prudential problems but rather because the plaintiffs did not satisfy the constitutionally mandated injury requirement, ${ }^{502}$ a deficiency which even Congress cannot override. There are two problems with this argument. First, as was already explained, Lujan imported what should be prudential worries into its injury analysis, ${ }^{503}$ preventing Congress from balancing the prudential worries. Second, it is unclear that Congress does not have the power to authorize standing even in the absence of an Article III injury. Although this Comment has

199 Blum, supra note 318 , at 141 . Blum's article interprets the legislative history of $\S 7$ in order to show Congress's international intentions.

${ }_{500}$ See supra notes $59-65$ and accompanying text.

501 See supra note 30 (explaining that citizen-suit provisions mark a congressional decision to let the courts hear certain cases).

${ }^{502}$ See Lujan, 112 S. Ct. at 2140 (noting that plaintiffs "fail[ed] to show injury").

${ }^{503}$ See supra notes 293-340 and accompanying text (discussing Lujan's inclusion of what should be nonconstitutional concerns into the injury requirement). 
heretofore assumed that Congress cannot extend standing where the Constitution would have denied it, ${ }^{504}$ this point is certainly not universally accepted.505 One commentator, Dean Nichol, argues that in Lujan, Justice Scalia "ignored the scholarship of the history of Article III ${ }^{m 566}$ by holding that courts cannot circumvent the Article III injury and act "at the invitation of Congress" to confer standing. ${ }^{507}$

Thus, Lujan abridged congressional power either by importing what should be prudential concerns into Article III or by eliminating Congress's ability to articulate the scope of Article III. In either case, the majoritarian Congress was denied its function of using its lawmaking power to grant standing to litigants. When Lujan restricted judicial access, it actually "transfer[red] power . . . at the expense-not of the courts-but of Congress, from which that power originates and emanates. ${ }^{508}$

${ }^{504}$ See supra notes 22, 25, 64, 493, 496 and accompanying text (noting that Congress can extend standing only as far as Article III allows).

${ }_{505}$ See, e.g., Warth v. Seldin, 422 U.S. 490, 500 (1975) ("The actual or threatened injury required by Art. III may exist solely by virtue of 'statutes creating legal rights, the invasion of which creates standing ...." (quoting Linda R. S. v. Richard D., 410 U.S. 614, 617 n.3 (1973))); Nichol, supra note 38, at 1152 (explaining that Congress may statutorily confer standing to individuals who would not otherwise satisfy Article III); Sunstein, supra note 63, at 214 (suggesting that there are "no limits on congressional creation of standing").

${ }^{506}$ Nichol, supra note 38 , at 1152.

${ }^{507}$ Lujan, 112 S. Ct. at 2144.

${ }^{508}$ Id. at 2158 (Blackmun, J., dissenting); see also Pierce, supra note 48 , at 1199 ("The majority opinion in [Lujan] transposes a doctrine of judicial restraint into a judicially enforced doctrine of congressional restraint."). The significance of Lujan's treatment of Congress's citizen-suit provision becomes strikingly apparent when Lujan is juxtaposed against earlier cases addressing legislatively conferred citizen standing. In Thomas v. New York, 802 F.2d 1443, 1445 (D.C. Cir. 1986), cert. denied, 107 S. Ct. 3196 (1987), the Administrator of the EPA sent a letter to the Secretary of State, indicating that sources in the United States were contributing to an excessive level of acid deposition. The main issue was whether $\$ 115$ of the Clean Air Act, 42 U.S.C. $\S 7415$ (a) (1982), legally obligated the Administrator's successors to address the acid deposition problem. See Thomas, $802 \mathrm{~F} .2 \mathrm{~d}$ at 1445 . The section requires the Administrator to address problems if she believes that sources in the United States are contributing to excessive pollution. See id. The provision does not specifically mention successors. The court granted standing relying mainly upon the fact the plaintiffs were suing pursuant to the "citizen-suit" provision of the Clean Air Act. Id. (citing 42 U.S.C. $\$ 7604(a)(2)$ (1982)). While the plaintiffs, several environmental groups, and American citizens, did satisfy Article III at the time, it is doubtful that they would satisfy the increased constitutional levels required in Lujan. Indeed, the plaintiffs' injury was based on "acid deposition, an injury not only majoritarian but also an injury whose redressability is questionable." Perino, supra note 286, at 170. It is doubtful that majoritarian injury of questionable redressability would survive Lujan. Ironically, Justice Scalia wrote both Thomas and Lujan; he has overruled 
Apart from its first argument that it did not abridge Congress's ability to grant standing because it denied standing due to constitutional obstacles, the Lujan Court would make a second argument that it did not abridge Congress's ability to grant standing. The Court would argue that it rightfully denied standing premised upon the congressionally authorized citizen-suit because even Congress, despite its automatic mitigation of certain separation of powers concerns, ${ }^{509}$ nevertheless implicates other separation of powers concerns when it permits the courts to hear a case at the executive branch's expense. Congress, by allowing the courts-and not the executive branch-to hear a case is violating separation of powers concerns. Yet the Lujan Court, by denying congressionally authorized standing, did not deprive Congress of any powers that Congress rightfully possessed. In fact, the Court explicitly said that permitting "Congress to convert . . . interest in executive officers' compliance with the law into an 'individual right' vindicable in the courts [would] permit Congress to transfer from the President to the courts the Chief Executive's most important constitutional duty, to "take Care that the laws be faithfully executed." 510 Thus, the Court is claiming that the citizen-suit provision of the ESA is constitutionally problematic due to a lack of congressional deference to separation of powers concerns.

There are two problems with this second argument. First, it is not clear that standing doctrine requires Congress to concern itself with abrogation of executive duties. As Professor Sunstein explained in his recent article on Lujan, "the relationship between standing limits and [executive duty] is at best ambiguous-and in the end, I believe, nonexistent." ${ }^{n 11}$ Sunstein argues further that the preservation of executive duty "however relevant it may be to many issues of administrative law, is irrelevant to the question of standing. ${ }^{512}$ Second, assuming that a congressional grant of standing was properly denied in Lujan to prevent improper abridgment of executive power, the case becomes even stronger for labelling this separation of powers problem as a prudential one. As explained earlier, the Lujan Court artificially increased the Article

himself.

${ }^{509}$ See supra notes 500-01 and accompanying text (noting how a congressional grant of standing alleviates some separation of powers worries).

${ }^{510}$ Lujan, 112 S. Ct. at 2145 (quoting U.S. CoNST. art. II, §3).

${ }^{511}$ Sunstein, supra note 63 , at 213.

512 Id. 
III standing requirements. ${ }^{513}$ Clearly, separation of powers was one reason for such an increase. ${ }^{514}$ The Court was probably concerned about the decrease in executive power as a result of the citizen-suit against an executive officer. ${ }^{515}$ Many citizen-suit provisions, however, allow for suit against an executive agency or against a private offender. ${ }^{516}$ Suits against an executive agency, such as Lujan, arguably implicate separation of powers considerations that should be included in the standing analysis. Problems arise, however, when these same concerns are imported into the three-pronged constitutional analysis instead of being examined as part of the flexible prudential analysis. In suits against private offenders, concerns about separation of powers are greatly decreased. ${ }^{517}$ The Lujan decision, however, prevents courts from considering such mitigated concerns by placing separation of powers concerns into the constitutional calculus. As a result of heightened Article III requirements, courts will not have the discretion to consider the varying weight of mitigated separation of powers concerns in citizen-suits against private offenders as compared to the increased separation of powers issues in citizensuits against the government. Lujan increased the constitutional requirements in both types of suits, ${ }^{518}$ leaving Congress with less power to grant judicial access-even against private offenders.

The citizen-suit provision of the ESA represents Congress's ability to overrule hesitations over separation of powers and internationalism. The main problem is that the Court in Lujan carried what should be prudential concerns into the Article III analysis, removing Congress's ability to eliminate these considerations through statute.

${ }^{513}$ See supra notes 293-371 and accompanying text.

514 See supra notes 293-302 and accompanying text (discussing how Lujan distorted Richardson in order to import separation of powers issues into Article III).

515 See supra note 510 and accompanying text.

${ }^{516}$ See, e.g., 42 U.S.C. $\$ 6972$ (a) (1988) (" [A]ny person may commence a civil action on his own behalf . . . against any person ... who is alleged to be in violation ... or ... against the Administrator ....").

${ }^{517}$ The separation of powers concern over displacement of executive power is "entirely inapplicable when the executive is not even a party." Sunstein, supra note 63 , at 231 (citation omitted).

${ }^{518}$ See id. at 165 ("[T]he decision invalidates the large number of statutes in which Congress has attempted to use the 'citizen-suit' ...."). While Lujan does not explicitly eliminate citizen suits, the increased Article III requirements have the practical effect of doing so. The heightened constitutional level prevents Congress from granting standing, even when the previous constitutional level would have been satisfied. 


\section{G. Harm to the Doctrine}

An additional consequence of the Court's distortion of the constitutional barrier is the harm that it will cause to the doctrine of standing, compromising predictability and efficiency in Article III jurisprudence. By including what should be nonconstitutional concerns in its Article III calculus, the Court makes it virtually impossible for future courts to ascertain a consistent standard. As Justice Blackmun stated in dissent, "I have the greatest of sympathy for the courts across the country that will struggle to understand the Court's standardless exposition."

In addition, Lujan's amorphous standing doctrine invites inefficient expenditure of judicial resources. Superficially, a standing doctrine such as the one enunciated in Lujan would appear to increase inefficiency by clearing federal dockets. Indeed, the Lujan case has "move[d] in ... [the] direction" of such efficiency. ${ }^{520}$ Nonetheless, the unpredictability of the Lujan decision will likely give rise to a different set of inefficiencies. Litigators, unable to predict accurately questions of standing, will create an "enormous volume of wasteful litigation about problems of standing. ${ }^{.521}$ The result in Lujan will "invite the very kind of wasteful and expensive wrangling that the public deplores and that we can ill afford."

Conversely, an analysis that focuses close attention on the distinction between constitutional and prudential considerations eliminates much of this unpredictability and inefficiency. If the Supreme Court were to restrict the constitutional analysis to its purpose of assuring the zealous advocacy which sharpens issues before the Court, ${ }^{523}$ courts would encounter fewer problems determining which litigants satisfied Article III. All litigants who demonstrated a redressable injury which promotes zealous advocacy would overcome the constitutional hurdles. Then, if the Supreme

${ }^{519}$ Lujan, 112 S. Ct. at 2158 (Blackmun, J., dissenting); see also DAvIs, supra note $6, \S 24: 1$ ("The main failure of the law of standing is ... the inconsistency . ...").

${ }^{520}$ Access to Justice, NAT'L L.J., Oct. 5, 1992, at 14. While judicial efficiency may be an appropriate consideration, a doctrine of standing premised entirely upon docket-clearing would be unacceptable. See Merrell Dow Pharmaceuticals, Inc. v. Thompson, 478 U.S. 804, 829-30 n.7 (1986) (Brennan, J., dissenting) ("It would be wholly illegitimate . . . for this Court to determine that there was no jurisdiction ... simply because the Court thought that there were too many cases in the federal courts.").

${ }^{521}$ DAVIS, supra note 6, § 24:2.

522 Richard Lazarus, Narrowed Standing is Harmful, NAT'L L.J., July 13, 1992, at 15.

${ }^{523}$ See supra notes 34-46 and accompanying text. 
Court still believed that the case should not be adjudicated based on prudential notions of judicial restraint, it could explicitly announce this view by pointing to a prudential consideration such as federalism, separation of powers, or internationalism. In the future, courts could predictably deny standing when such concerns were implicated.

\section{Harm to Plaintiffs}

When the Court imports what should be prudential concerns into Article III, it denies courts and Congress the ability to grant standing to many proper litigants. After Lujan, it is possible that plaintiffs who satisfy Article III and do not implicate any prudential worries will nonetheless be denied access. The greatest consequence of this importation is that plaintiffs may be denied their day in federal court. From John Madsen ${ }^{54}$ to foreign farmworkers, ${ }^{525}$ from postal workers $^{526}$ to Amy Skilbred, ${ }^{527}$ the Court's distortion of standing doctrine will deprive plaintiffs of federal judicial justice.

Perhaps the most damaging denial of standing in all these cases involved Amy Skilbred. Skilbred, a member of Defenders of Wildlife, brought suit for an injury to her vocational and aesthetic interests in the preservation of certain endangered species. ${ }^{528}$ But it is difficult to overlook the point that an endangered species's survival may depend on the outcome of Ms. Skilbred's suit. Because it is quite clear that environmental beings themselves do not have standing to bring suit, ${ }^{529}$ their interest in survival rests upon a

${ }^{524}$ See Madsen v. Boise State Univ., 976 F.2d 1219, 1222 (9th Cir. 1992).

${ }^{525}$ See Snake River Farmers' Ass'n, Inc. v. Department of Labor, 9 F.3d 792, 797 (9th Cir. 1993).

${ }^{526}$ See American Postal Workers Union v. Frank, 968 F.2d 1373, 1376 (1st Cir. 1992).

${ }^{527}$ See Lujan, 112 S. Ct. at 2146.

${ }^{528} \mathrm{See}$ id. at 2138.

${ }^{529}$ See Sierra Club v. Morton, 405 U.S. 727, 738-41 (1972) (holding that the Sierra Club could not sue on behalf of the environment itself). Renowned commentators have criticized the rejection of suits on behalf of the environment. See generally Christopher D. Stone, Should Trees Have Standing?-Toward Legal Rights for Natural Objects, 45 S. CAL. L. REV. 450 (1972) (arguing that the environment itself, if it suffers a redressable injury, should have standing to sue). While the Court in Sierra Club rejected this notion, it did receive some support in dissent: "The critical question of 'standing' would be simplified and also put neatly in focus if we . . . allowed environmental issues to be litigated ... . in the name of the inanimate object about to be despoiled, defaced, or invaded ...." Sierra Club, 405 U.S. at 741 (Douglas, J., dissenting) (citation omitted). Professor Stone's proposal, supported by Justice 
grant of standing to plaintiffs like Ms. Skilbred. In effect, the environment was denied standing as well as Ms. Skilbred. ${ }^{530}$ Apart from damaging Ms. Skilbred, such a decision could irreparably damage the environment.

Consider the plight of the Asian elephant. The species, now concentrated primarily in Southeast Asia, is already threatened..$^{531}$ As part of its annual migration, the elephant travels a route which includes a stop at the Mahaweli River in Sri Lanka for feeding. ${ }^{532}$ Without the opportunity to feed at the Mahaweli River, its population could be decimated, causing "particularly disastrous" results. The Mahaweli project, funded in part by United States' agencies, will create the Mahaweli Dam. ${ }^{534}$ This dam "could have massive environmental impacts on such an insular ecosystem as the Mahaweli River system. ${ }^{n 55}$ The project, if completed, could

Douglas, has never gained majority support, as the following poetic state court opinion suggests:

We thought that we would never see

A suit to compensate a tree.

A suit whose claim in tort is prest

Upon a mangled tree's behest;

A tree whose battered trunk was prest

Against a Chevy's crumpled crest;

A tree that faces each new day

With bark and limb in disarray;

A tree that may forever bear

A lasting need for tender care.

Flora lovers though we three

We must uphold the court's decree.

Fisher v. Lowe, 333 N.W.2d 67, 67 (Mich. Ct. App. 1983) (opinion appears in its entirety).

${ }^{530}$ Several sources suggest that the Court increases its constitutional requirements to extreme levels specifically in the area of environmental litigation. See, e.g., Lujan, 112 S. Ct. at 2154 (Blackmun, J., dissenting) (criticizing the Court for failing to recognize that "environmental plaintiffs are under no special constitutional standing disabilities"); Jeanne A. Compitello, Organizational Standing in Environmental Litigation, 6 TOURO L. REv. 295, 296 (1990) ("[T]here have been too many hurdles created for those who want to protect the environment .... ."); Perino, supra note 286, at 179 ("Scalia will ... cut[] back the Court's potentially powerful role in promoting the environmental agenda."); Robichaud, supra note 60, at 449 (analyzing the "recent wave of cases denying standing to environmental plaintiffs"); Sunstein, supra note 63, at 221 (noting that the invalidation of the citizen-suit provisions will be particularly harmful to environmental laws).

${ }^{531}$ See Respondents' Brief at 21, Lujan (No. 90-1424).

${ }^{532}$ See id. at 18.

${ }^{533} \mathrm{Id}$.

${ }^{534}$ See id.

${ }^{555} \mathrm{Id}$. 
permanently destroy the Asian elephant. ${ }^{536}$ By denying standing to Defenders of Wildlife, the Court in Lujan may ultimately permit the extinction of the Asian elephant. Perhaps the famous conservationist Aldo Leopold best explained the effect of the loss of a species: "The opportunity to see geese is more important than the television, and the chance to find a pasque-flower is a right as inalienable as free speech." 537

\section{CONCLUSION}

It is often true that "[g]eneralizations about standing to sue are largely worthless as such. ${ }^{\text {538 }}$ Yet one standing generalization is quite worthwhile: " $[t]$ his constitutional-prudential distinction is very important. ${ }^{759}$ It can make the difference between a grant of standing and a denial of standing; it can make the difference between judicial access for a litigant and lack of access for a litigant; it can make the difference between life and death. The Supreme Court has distorted the Article III limitations on standing by importing what should be prudential concerns into its constitutional analysis. Consequently, courts and Congress will be prevented from granting standing to zealous advocates who do not implicate prudential worries. Many deserving plaintiffs will be deprived of their day in court. Such a denial of standing can have tragic and irreversible effects. A plaintiff could be denied the chance to challenge harmful government conduct. ${ }^{540}$ The consequences of this denial could range from the loss of a parking spot $t^{541}$ to the loss of a son ${ }^{542}$ to the loss of an entire species. The stakes are high. The Supreme Court's muddling of the constitutional and

${ }^{536}$ See id.

537 Aldo Leopold, A SANd County Almanac vii (1949); see also Sierra Club v. Morton, 405 U.S. 727, 751 n.8 (1972) ("'When a species is gone, it is gone forever. Nature's genetic chain, billions of years in the making, is broken for all time." (quoting CONSERVE-WATER, LAND AND LIFE, Nov. 1971, at 4)).

598 Association of Data Processing v. Camp, 397 U.S. 150, 151 (1970).

539 Bullock, supra note 27, at 614 .

${ }^{540}$ See, e.g., Lujan, 112 S.Ct. at 2146 (denying standing to challenge governmental failure to take environmental precautions); EKWRO, 426 U.S. at 43 (denying standing to challenge government subsidies); Warth v. Seldin, 422 U.S. 490, 512 (1975) (denying standing to challenge official discrimination); Alabama Power Co. v. Ickes, 302 U.S. 464, 478 (1938) (denying standing to challenge government competition).

${ }^{541}$ See Madsen v. Boise State Univ., 976 F.2d 1219, 1222 (9th Cir. 1992).

542 See Gilmore v. Utah, 429 U.S. 1012, 1013 (1976) (denying mother of death row inmate standing to file application for stay of execution). 
prudential concerns has caused this judicial access doctrine to fall. The proper allocations of these concerns will allow it to stand. 
